UNIVERSIDADE ESTADUAL PAULISTA “JÚLIO DE MESQUITA FILHO” FACULDADE DE CIÊNCIAS AGRONÔMICAS CAMPUS DE BOTUCATU

\title{
AVALIAÇÃO DE SISTEMAS DE MANEJO DO PALHIÇO DE CANA- DE-AÇÚCAR NO CAMPO E NA INDÚSTRIA
}

\section{LUIZ ANTONIO PEREA}

Tese apresentada à Faculdade de Ciências Agronômicas da UNESP - Campus de Botucatu, para obtenção do título de Doutor em Agronomia - Energia na Agricultura. 
UNIVERSIDADE ESTADUAL PAULISTA “JÚLIO DE MESQUITA FILHO” FACULDADE DE CIÊNCIAS AGRONÔMICAS

CAMPUS DE BOTUCATU

\section{AVALIAÇÃO DE SISTEMAS DE MANEJO DO PALHIÇO DE CANA- DE-AÇÚCAR NO CAMPO E NA INDÚSTRIA}

\section{LUIZ ANTONIO PEREA}

Orientador: Prof. Dr. Marco Antonio Martin Biaggioni

Co-orientador: Prof. Dr. Odivaldo José Seraphim

Tese apresentada à Faculdade de Ciências Agronômicas da UNESP - Campus de Botucatu, para obtenção do título de Doutor em Agronomia - Energia na Agricultura.

BOTUCATU-SP

Novembro -2009 
FICHA CATALOGRÁFICA ELABORADA PELA SECh̆o TÉCNICA DE AQUISIÇగ̆o E TRATAMENTO DA INFOPMACXKO - SERVIÇO TÉCAICO DE BIBLIOTECA E DOCUMENTACÃO UNESP - FCA LAGEADO - BOTUCATU (SP)

Avaliação de sistemas de manejo do palhiço de cana-deaçúcar no campo e na indústria / Luiz Antonio Perea. - Botucatu, [s.n.], 2009.

viii, 93 f. : il., color, grafs,, tabs.

Tese (Doutorado) - Universidade Estadual Paulista, Faculdade de Ciências Agronômicas, Botucatu, 2009

orientador: Marco Antonio Martin Biaggioni

Co-orientador: Odivaldo José Seraphim

Inclui bibliografia

1. Biomassa. 2. Cogeração de energia. 3. Palhiço de canade-açúcar. I. Biaggioni, Marco Antonio Martin. II. Seraphim, odivaldo José. III. Universidade Estadual paulista nJulio de Mesquita Filho" (Campus de Botucatu). Faculdade de Ciências Agronômicas. IV. Título. 


\section{UNIVERSIDADE ESTADUAL PAULISTA “JÚLIO DE MESQUITA FILHO"}

FACULDADE DE CIÊNCIAS AGRONÔMICAS

\section{CAMPUS DE BOTUCATU}

\section{CERTIFICADO DE APROVAÇÃO}

TítUlo: "Avaliação De sistemas de manejo do Palhiço de CANA-DEaĆÚCAR NO CAMPO E NA INDÚSTRIA"

ALUNO: LUIZ ANTONIO PEREA

ORIENTADOR: PROF. DR. MARCO ANTONIO MARTIN BIAGGIONI

Aprovado pela Comissão Examinadora
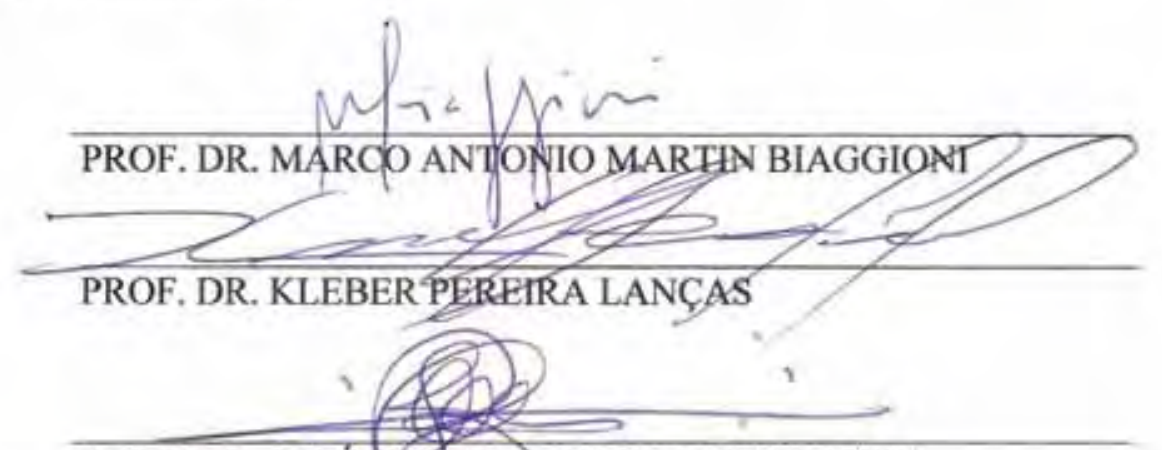

PROF. DR. JOSÉ ROGERTg CORREA SAGLIETTI

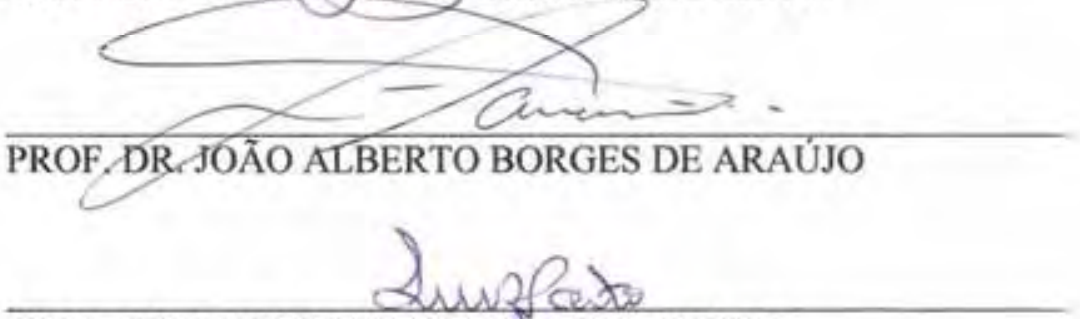

PROF. DR. LUIZ GONZAGA CAMPOS PORTO

Data da Realização: 27 de novembro de 2009. 
A memória de meu pai Antonio, a minha mãe Walderes, que muito contribuíram para minha formação e educação. A Domingas Tereza minha esposa, Luiz Gustavo, Luiza Fernanda e Liza Mirela meus filhos, que muito incentivaram o meu retorno aos bancos acadêmicos. 


\section{AGRADECIMENTOS}

À Faculdade de Ciências Agronômicas (FCA - UNESP), campus de Botucatu e à Coordenadoria do Programa de Pós Graduação em Agronomia - Energia na Agricultura, pela oportunidade:

ao orientador Prof. Dr. Marco Antonio Martins Biaggioni, pelo grande apoio recebido na realização deste trabalho;

ao Prof. Dr. Odivaldo José Seraphim, meu co-orientador, pelo estímulo recebido;

aos Professores Doutores: Sérgio Campos, Antonio Evaldo Klar e Marcos Roberto Bórmio, pelo convívio de inestimável valor e conhecimentos recebidos;

aos funcionários do Departamento de Engenharia Rural, da Seção de Pós Graduação e da Biblioteca, pela prestatividade e atenção;

aos colegas de trabalho Walter Luiz Polonio, Luis Fernando Antunes, Bernardo Yasuhiro Ide, Achiles Aparecido Mollon, Paulo de Tarso Delfini, Valdeci Bérgamo, Varlei Francisco, Jose Carlos Previeiro e Jair Florêncio, e aos Eng. Marcos Sader, e Raul Marcel Daré, pela grande ajuda prestada na elaboração do trabalho;

a todos os colegas contemporâneos do curso de Doutorado em Agronomia - Energia na Agricultura, pela união e amizade. 


\section{SUMÁRIO}

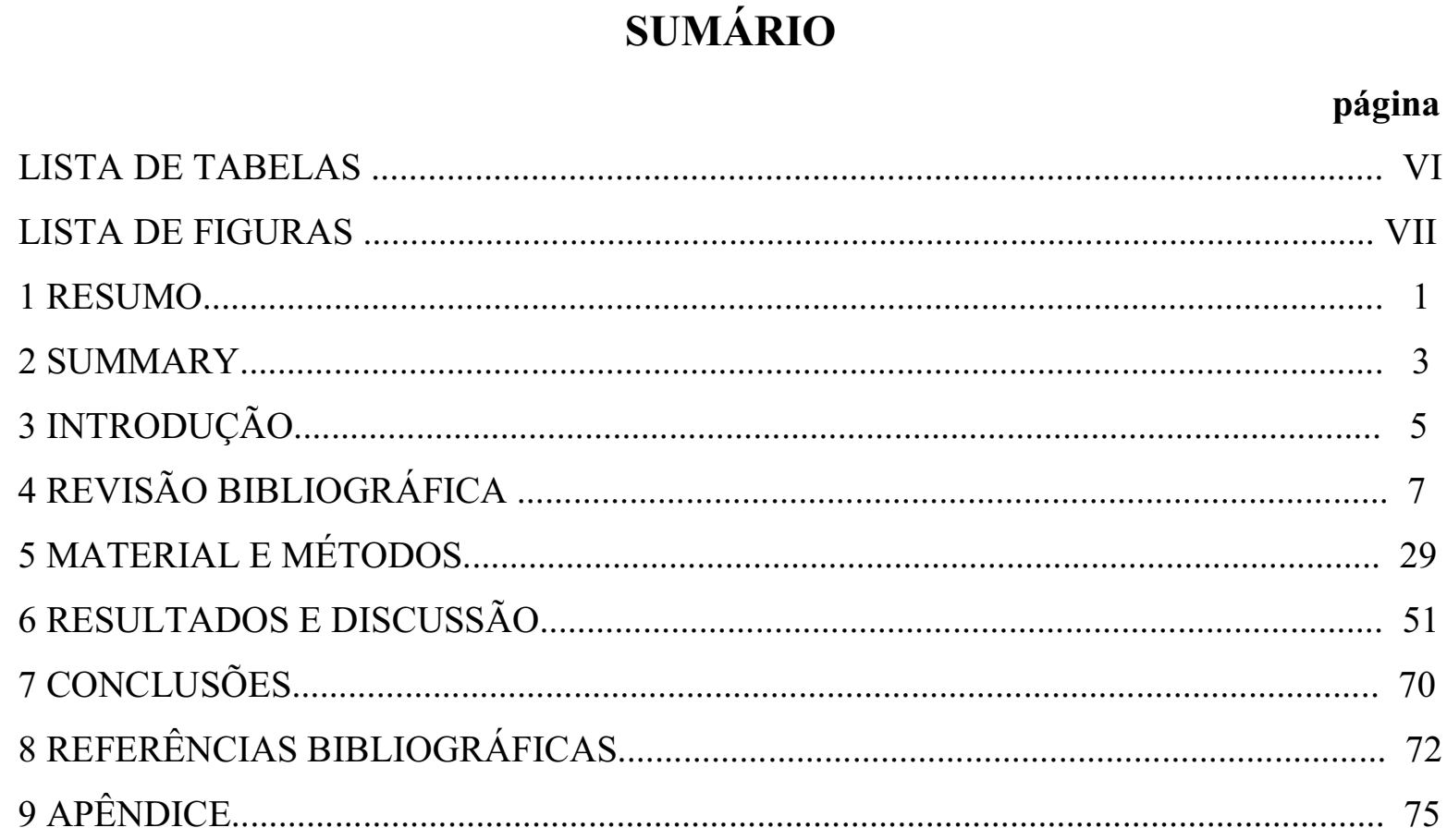




\section{LISTA DE TABELAS}

página

Tabela 1 - Expansão da bioeletricidade no Brasil com o uso de bagaço + palhiço. 8 Tabela 2 - Potencial de geração de energia elétrica segundo as tecnologias utilizadas de vapor e processo - base 2004 . 8

Tabela 3 - Disponibilidade de biomassa seca de resíduos da colheita da cana-de-açúcar no Brasil 9

Tabela 4 - Comparação do Poder Calorífico - palhiço e bagaço.

Tabela 5 - Propriedades físico-química do palhiço e do bagaço da cana-deaçúcar/Caracterização palhiço-bagaço.

Tabela 6 - Estimativa da quantidade de palhiço em diversas variedades de cana-de-açúcar.. 13 Tabela 7 - Resultado da pesquisa do potencial de palhiço em diversas variedades de cana-deaçúcar

Tabela 8 - Potencial de bioeletricidade estimado pelo número de empreendimentos cadastrados nos leilões de energia realizados em 2008 (A3,A5 e Energia de Reserva)......... 17

Tabela 9 - Resultados obtidos no recolhimento do palhiço com máquina forrageira

Tabela 10 - Resultados comparativos de recolhimento do palhiço em solo arenoso e solo argiloso

Tabela 11 -Resultados de recolhimento de palhiço obtidos com a colhedora Twyster em condições de umidade.

Tabela 12 - Rendimentos calculados para 20 horas de trabalho da colhedora Twyster.

Tabela 13 - Custo do palhiço recolhido pelo sistema de máquinas Twyster.

Tabela 14 - Resultados operacionais do recolhimento do palhiço com máquina enfardadora.

Tabela 15 - Resultados econômicos do recolhimento do palhiço com máquina enfardadora. 59

Tabela 16 -Resultados das amostras antes das sopragens 60

Tabela 17 - Resultados obtidos após a primeira sopragem. 63

Tabela 18 - Resultados obtidos após a segunda sopragem. 64 


\section{LISTA DE FIGURAS}

página

Figura 1 - Fluxograma mostrando a separação do palhiço no campo, de acordo com a alternativa 1 e os resultados percentuais por etapas.

Figura 2 - Fluxograma mostrando a separação do palhiço na indústria, de acordo com a alternativa 2 e os resultados percentuais por etapas.

Figura 3 - Fluxograma mostrando a separação parcial do palhiço no campo e na indústria, de acordo com a alternativa 3 e os resultados parciais por etapas............................................ 11

Figura 4 - Caracterização do palhiço da cana-de-açúcar......................................................... 12

Figura 5 - Potencial de produção de biomassa no mundo em grama de matéria seca $/ \mathrm{m}^{2} /$ ano. 14 Figura 6 - Área de produção de cana-de-açúcar no Brasil....................................................... 15

Figura 7 - Mapa da expansão da indústria da cana-de-açúcar no Brasil.................................. 16

Figura 8 - Balanço Estático de Energia Elétrica do MME 2007........................................... 17

Figura 9 - Cronograma do Programa de Eliminação de Queimadas em São Paulo................. 22

Figura 10 - Novo cronograma da eliminação de queimadas em terras mecanizáveis..............23

Figura 11 - Novo cronograma da eliminação de queimadas em terras não mecanizáveis ......23

Figura 12 - Comparação entre áreas de cana-de-açúcar colhidas com e sem queimada, safras 06/07 a 08/09.

Figura 13 - Comparação entre a Lei 11.241/02, Protocolo agroambiental e dados reais de queima. 25

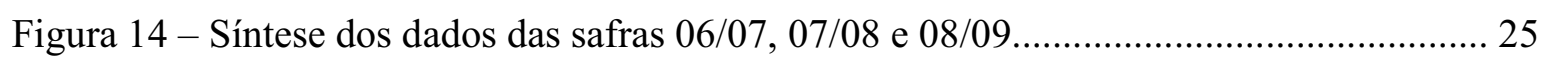

Figura 15 - Evolução das populações da cigarrinha-da-raiz.................................................. 27

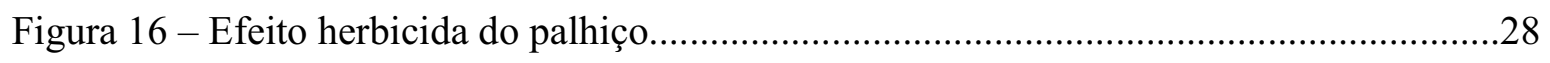

Figura 17 - Colhedora Class Jaguar 860 recolhendo palhiço enleirado...................................33

Figura 18 - Caminhão com palhiço sendo descarregado no pátio de bagaço........................... 34

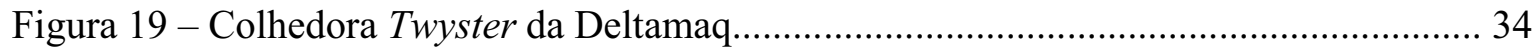

Figura 20 - Colhedora Twyster Press 5000 em operação recolhendo palhiço sem

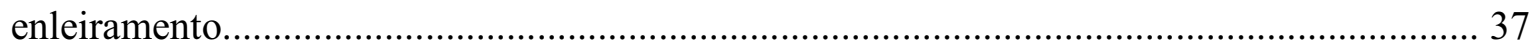

Figura 21 - Transferência de palhiço da colhedora para a carreta Twyster Box..................... 37 
Figura 22 - Carregamento de caminhão basculante realizado pela carreta Twyster Box........ 38

Figura 23 - Fardos cilíndricos no campo, aguardando transporte.......................................... 39

Figura 24 - Carregamento de palhiço em caminhões de transporte de cana-de-açúcar.............41

Figura 25 - Palhiço sendo tombado nas mesas alimentadoras da moenda................................41

Figura 26 - Palhiço sendo conduzido à moenda pelas esteiras transportadoras........................42

Figura 27 - Palhiço sendo moído em dos ternos da moenda de cana-de-açúcar.......................42

Figura 28 - Nivelador instalado na esteira de cana-de-açúcar...............................................44

Figura 29 - Conjunto nivelador e bico soprador...................................................................

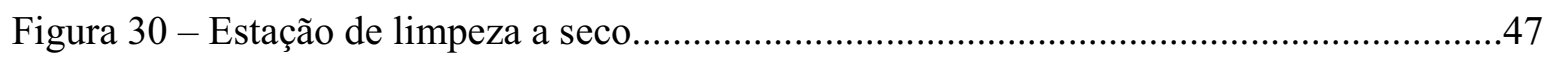

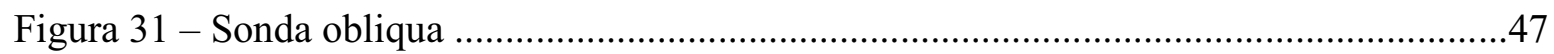

Figura 32 - Perda da capacidade de transporte em relação ao \% de palhiço colhido, amostra

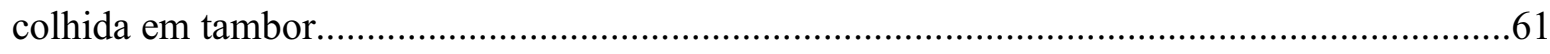

Figura 33 - Perda da capacidade de transporte em relação ao \% de palhiço colhido, amostra

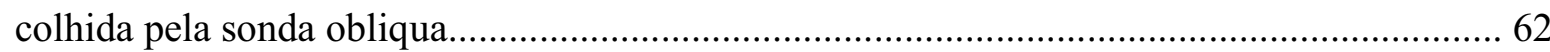

Figura 34 - Resultados de eficiência de separação de palhiço na indústria, pelo método do tambor. 65

Figura 35 - Resultados de eficiência de separação de palhiço na indústria, pelo método da

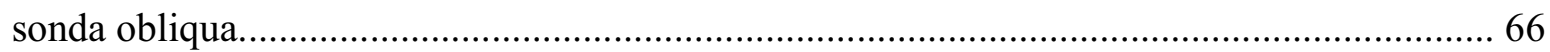

Figura 36 - Eficiência de separação do palhiço pelos métodos tambor e sonda obliqua..........67

Figura 37 - Impureza mineral recebida com a cana-de-açúcar (método do tambor)...............68

Figura 38 - Impureza mineral após a primeira sopragem (método do tambor).......................68

Figura 39 - Impureza mineral após a segunda sopragem (método do tambor)........................68 


\section{RESUMO}

Este trabalho apresenta e avalia o estado da arte de sistemas de colheita de palhiço da cana-de-açúcar para fins energéticos, por meio de estudos realizados em três indústrias do Estado de São Paulo, como recolhimento no campo e na modalidade mais praticada, que é a colheita mecanizada da cana-de-açúcar parcialmente integral e tem como foco principal a separação do palhiço na indústria por jato de ar soprado, ou seja, limpeza a seco. Esta modalidade além da remoção do palhiço que se deseja aproveitar remove também, as impurezas minerais que são prejudiciais para o processo de industrialização da cana-deaçúcar. Trata-se de um desenvolvimento de oportunidades, pois somente quando há escassez de bagaço é que se volta a lembrar do uso energético do palhiço, o qual apresenta um custo maior por tonelada equivalente em energia que o bagaço da cana-de-açúcar, que já tem um comércio bem difundido dentro do setor sucroalcooleiro.

Outro fator que deve ser destacado é o ambiental, visto que existe o Protocolo Ambiental sancionado pela maioria dos produtores e usinas do Estado de São Paulo, que reduz o prazo para eliminação das queimadas da cana-de-açúcar antes da colheita, implantado pela Lei 11241 de 2002. As queimadas, além dos danos ao meio-ambiente, também provocam a morte de muitos animais silvestres, porém é importante lembrar ainda que a colheita da cana-de-açúcar crua (sem queima prévia) aumenta a dificuldade do combate da praga importante denominada "cigarrinha-da-raiz", tornando necessária a retirada de parte do palhiço inútil para o solo, contribuindo assim, com a prática de remoção do palhiço para aproveitamento energético. 
A metodologia adotada foi a comparação da modalidade de recolhimento de palhiço no campo através de máquinas forrageiras, uma máquina especialmente projetada para a finalidade, e com a modalidade de separação na indústria, pelo processo de limpeza a seco.

$\mathrm{Na}$ modalidade recolhimento no campo para máquina forrageira, os principais resultados obtidos foram: produtividade de recolhimento de 4,95 t/ha; umidade média de 10,7\%; impureza mineral de 7,54\% e custo do palhiço posto na usina de R $\$ 58,14 /$ t. Para máquina colhedora Twyster foram: produtividade de recolhimento 4,83 t/ha; umidade média 13,92\%; impureza mineral $3,41 \%$ e custo do palhiço posto usina $\mathrm{R} \$ 63,02 /$ t. Para máquina colhedora e enfardadora foram: produtividade de recolhimento e enfardamento 6,89 t/ha, umidade média 16\%, impureza mineral $8 \%$ e custo do palhiço posto usina $\mathrm{R} \$ 69,44 / \mathrm{t}$.

Para a modalidade de separação na indústria, foram efetuadas amostragem de palhiço contido nas cargas de cana-de-açúcar devidamente selecionadas e preparadas para os experimentos, onde existiu a variação da quantidade de palhiço colhido junto com a cana-de-açúcar, através da variação da velocidade de rotação do extrator de palhiço da máquina colhedora. Os principais resultados obtidos foram; para material amostrado antes da separação: 5,21\% de palhiço recebido com a cana-de-açúcar colhida com extrator da colhedora em $900 \mathrm{rpm}$ e com umidade média de $41,20 \% ; 11,85 \%$ de palhiço recebido com a cana-de-açúcar com extrator da colhedora a $650 \mathrm{rpm}$ e com umidade média de $36,78 \%$.

Na primeira sopragem a eficiência média de separação foi de 55,92\% e 68,63\% respectivamente; com a segunda sopragem foram obtidas eficiências médias de $67,26 \%$ e $83,20 \%$. O custo do recolhimento do palhiço para separação na indústria foi o mesmo do corte, carregamento e transporte da cana-de-açúcar durante o experimento, $\mathrm{R} \$$ 19,75/t. Para a operação de separação do palhiço foram estimados custos de R\$ 11,00/t. tornando então o custo total dessa modalidade R\$ 30,75/t.

Dos resultados obtidos concluiu-se que a modalidade mais interessante economicamente foi a da separação do palhiço na indústria e que para melhor eficiência, a cana-de-açúcar deve passar por um processo duplo de sopragem, ressaltando, porém, que houve redução da capacidade de transporte quanto maior foi a quantidade de palhiço na colheita parcialmente integral. 
EVALUATION OF METHODS OF TRASH HANDLING IN THE SUGAR-CANE
FIELD AND INDUSTRIALIZATION. Botucatu, 2009. 101p. Tese (Doutorado em Agronomia/Energia na Agricultura) - Faculdade de Ciências Agronômicas, Universidade Estadual Paulista.

Author: LUIZ ANTONIO PEREA

Adviser: MARCO ANTÔNIO MARTIN BIAGGIONI

Co-Adviser: ODIVALDO JOSÉ SERAPHIM

\section{SUMMARY}

This paper presents and it evaluates the state of the art of systems of crop of trash of the sugar-cane for energy ends, through studies accomplished in three industries of the State of São Paulo, as withdrawal in the field and in the modality more practiced, that is partially the automated crop of the sugar-cane integral and he has as main focus the separation of the trash in the industry for jet of blown air, in other words, cleaning the dry. This modality besides the removal of the trash that one want to take advantage of also removes, the mineral sludge that are harmful for the process of industrialization of the sugarcane. It is treated of a development of opportunities, because only when there is no have bagasse enough it is that remembers the energy use of the trash, which presents a larger cost for equivalent ton in energy that bagasse, that already has inside a very spread trade in the sugar and alcohol production sectors.

Another factor that should be outstanding is the environmental, because the Environmental Protocol sanctioned by most of the producers of sugar-cane, sugar and alcohol of the State of São Paulo, reduces the period for elimination of the burned of the sugar-cane before the crop, implanted by the Law 11241 of 2002 . The burned ones, besides the damages to the middle-atmosphere, also provoke the death of many you encourage wild, however it is important to remind although the crop of the raw sugar-cane (without it burns previous) it increases the difficulty of the combat the pest denominated "cigarrinha-da-raiz", when is necessary removing the trash that is no useful the soil, contributing for the practice of trash removal for energy use. 
The adopted methodology was comparison of the modality of trash removal in the field through harvest machines, a machine especially projected for the purpose, and with the separation modality in the industry, for the process of cleaning the dry.

In the modality removal in the field for fodder machine, the principal obtained results were: productivity of withdrawal of 4,95 t/ha; medium humidity of $10,7 \%$; mineral impurity of $7,54 \%$ and I cost of the put trash in the plant of R\$ 58,14/t. Para harvest machine Twyster were: productivity of withdrawal 4,83 t/ha; medium humidity 13,92\%; mineral impurity $3,41 \%$ and I cost of the trash puts plant $\mathrm{R} \$ 63,02 / \mathrm{t}$. Para harvest and baler machine were: withdrawal productivity and baler $6,89 \mathrm{t} / \mathrm{ha}$, medium humidity $16 \%$, mineral impurity $8 \%$ and I cost of the trash puts plant R $\$ 69,44 / t$.

For the separation modality in the industry, they were made trash sampling contained properly in the sugar-cane loads selected and prepared for the experiments, where the variation of the amount of trash existed picked with the sugar-cane, through the variation of the speed of rotation of the extractor of trash of the harvest machine. The principal obtained results were; for material sampled before the separation: 5,21\% of trash received with the sugar-cane picked with extractor of the harvest machine in $900 \mathrm{rpm}$ and with medium humidity of $41,20 \% ; 11,85 \%$ of trash received with the sugar-cane with extractor from the harvest machine to $650 \mathrm{rpm}$ and with medium humidity of $36,78 \%$.

In the first blowing the medium efficiency of separation was respectively of $55,92 \%$ and $68,63 \%$; with the second blowing they were obtained medium efficiencies of $67,26 \%$ and $83,20 \%$. The cost of the withdrawal of the trash for separation in the industry was the same of the cut, shipment and transport of the sugar-cane during the experiment, R\$ 19,75/t. Para the operation of separation of the trash was dear costs of R\$ $11,00 / t$. turning the total cost of that modality $\mathrm{R} \$ 30,75 / \mathrm{t}$ then.

Of the obtained results it was ended that the most interesting modality economically was the one of the separation of the trash in the industry and that for better efficiency, the sugar-cane should go by a double process of blowing, pointing out however, that there was reduction of the transport capacity as adult was the amount of trash partially in the full crop.

Keywords: trash of the sugar-cane, biomass, efficiency of cleaning. 


\section{INTRODUÇÃO}

A utilização do palhiço da cana-de-açúcar como combustível em caldeiras a vapor pode ser viável técnica e economicamente desde que a mesma seja processada convenientemente e também, possibilite sua incorporação ao bagaço sem grandes modificações nas instalações existentes.

Para isso, desde a década de 90, a Copersucar, cooperativa mantida por diversas indústrias sucroalcooleiras, vem pesquisando equipamentos para o recolhimento e trituração do palhiço para o seu aproveitamento como combustível. Nos últimos anos, a Copersucar, agora CTC - Centro de Tecnologia Canavieira fez alguns testes com trituradores de pequenas dimensões e capacidades.

O palhiço da cana-de-açúcar, por ser um material de baixo peso específico e com grande variação no tamanho das fibras, é de difícil manuseio e suas características reduzem significativamente a capacidade das máquinas. Como o palhiço é disponibilizado no campo em grandes quantidades, a característica de capacidade de recolhimento tem grande importância na seleção dos equipamentos.

Outras indústrias sucroalcooleiras, não cooperadas, também estão pesquisando diferentes maneiras para coleta do palhiço no campo e processamento industrial, desde a sua compactação tipo "enfardamento", para facilitar o transporte e posterior trituração, bem como coleta através de máquinas tipo forrageira, recolhendo e triturando o palhiço, ou até colhendo-o junto com o corte mecanizado da cana-de-açúcar, conhecido como colheita parcialmente integral da cana-de-açúcar. 
O presente trabalho teve como objetivo realizar uma avaliação no desempenho de sistemas de coleta e separação de palhiço de cana-de-açúcar, praticados na região central do Estado de São Paulo, visando seu aproveitamento como combustível em caldeiras a bagaço de cana-de-açúcar, e verificar a eficiência de separação em um sistema otimizado aerodinamicamente, realizando a sopragem da cana-de-açúcar por duas vezes. 


\section{REVISÃO BIBLIOGRÁFICA}

\subsection{Potencial do uso energético do palhiço da cana-de-açúcar.}

Após a escassez na oferta de energia elétrica em 2001, o governo brasileiro passou a incentivar a procura de fontes alternativas à hídrica, para geração de eletricidade, sendo uma delas a biomassa.

Braunbeck (2005) relatou que: “O bagaço tem sido o único resíduo aproveitado da biomassa do canavial, principalmente porque está disponível espontaneamente ao lado da caldeira da indústria. Até hoje se fala muito pouco sobre o aproveitamento do palhiço, mas deve surgir uma valorização da energia embutida no palhiço diante da atual crise de escassez". "A única forma de efetuar o corte da cana-de-açúcar manualmente é com a queimada. No entanto, a Lei 11241/02 determina que boa parte da colheita seja feita sem queima prévia, o que poucos obedecem, mesmo se sujeitando a multas. Os produtores não obedecem porque não encontram uma tecnologia de colheita adequada; as conhecidas impõem altos investimentos e perdas altas e qualidade baixa. Concebida inicialmente para reduzir o custo da colheita e dar mais qualidade a cana-de-açúcar, a máquina ganhou uma nova dimensão diante da crise energética no país por seu potencial de aproximadamente 30 milhões de toneladas/ano de palhiço que atualmente são queimadas no Brasil”. A Tabela 1 demonstra o potencial de exportação de bioeletricidade e a disponibilidade de biomassa através da produção da cana-de-açúcar, bagaço e palhiço. 
Tabela 1 - Expansão da bioeletricidade no Brasil com o uso de bagaço + palhiço.

\begin{tabular}{ccccccccc}
\hline Safra & $\begin{array}{c}\text { Cana-de- } \\
\text { açúcar }\end{array}$ & Bagaço & $\begin{array}{c}\text { Palhiço e } \\
\text { ponta }\end{array}$ & $\begin{array}{c}\text { Bagaço + Potencial (só bagaço) } \\
\text { palhiço }\end{array}$ & $\begin{array}{c}\text { Potencial (bagaço + } \\
\text { palhiço) }\end{array}$ \\
\hline & milhões t & milhões t & milhões t & milhões t & GWh/ano & MW médio & GWh/ano MW médio \\
\hline $2006 / 07$ & 425 & 106 & 87 & 193 & 12.684 & 1.448 & 12.684 & 1.448 \\
\hline $2007 / 08$ & 460 & 115 & 94 & 209 & 15.599 & 1.781 & 17.356 & 1.981 \\
\hline $2008 / 09$ & 502 & 126 & 102 & 228 & 19.226 & 2.199 & 23.837 & 2.721 \\
\hline $2009 / 10$ & 547 & 137 & 112 & 248 & 23.889 & 2.727 & 32.863 & 3.751 \\
\hline $2010 / 11$ & 601 & 150 & 123 & 273 & 29.745 & 3.396 & 45.495 & 5.193 \\
\hline $2011 / 12$ & 659 & 165 & 134 & 299 & 37.201 & 4.247 & 63.264 & 7.222 \\
\hline $2012 / 13$ & 728 & 182 & 149 & 331 & 46.737 & 5.335 & 88.332 & 10.084 \\
\hline
\end{tabular}

Fonte: CogenSP

Hassuani (2005) citou que a maioria das usinas brasileiras que produz energia através da cana-de-açúcar desenvolve o processo para consumo próprio, em caldeiras de baixa pressão. Nesse sistema, em razão do baixo ganho energético, o palhiço não faz diferença. Mas se as usinas trocarem o equipamento por caldeiras de alta pressão, e gerarem energia com o bagaço da cana-de-açúcar, a adição do palhiço pode, sozinha, dobrar a produção de energia. Uma tonelada de bagaço de cana-de-açúcar em um sistema de alta pressão gera cerca de 50 quilowatts/hora. Com o palhiço, isso vai a 100 quilowatts/hora usando-se as tecnologias (3) ou (4) da Tabela 2.

Tabela 2 - Potencial de geração de energia elétrica segundo as tecnologias utilizadas de vapor e processo- base 2004

\begin{tabular}{|c|c|c|c|c|c|c|}
\hline \multirow{2}{*}{$\begin{array}{c}\text { Tecnologia } \\
\text { utilizada }\end{array}$} & \multirow{2}{*}{$\begin{array}{l}\text { Periodo de } \\
\text { operação }\end{array}$} & \multirow{2}{*}{$\begin{array}{c}\text { Consumo de } \\
\text { vapor no } \\
\text { processo } \mathrm{kgv} / \mathrm{tc}\end{array}$} & \multirow{2}{*}{$\begin{array}{c}\text { Excedente de } \\
\text { energia } \\
\mathbf{k W h} / \mathrm{tc}\end{array}$} & \multicolumn{2}{|c|}{ Potencial Brasil } & \multirow{2}{*}{$\begin{array}{c}\text { \% Consumo } \\
\text { Brasil }\end{array}$} \\
\hline & & & & GWh & MW & \\
\hline $\begin{array}{c}(1)-22 \text { bar - } \\
300^{\circ} \mathrm{C} \text { TG } \\
\text { Contrapressão }\end{array}$ & Safra & 500 & $0-10$ & 3.600 & 900 & 1 \\
\hline $\begin{array}{c}\text { (2) - 80bar - } \\
480^{\circ} \mathrm{C} \text { TG } \\
\text { Contrapressão }\end{array}$ & Safra & 500 & $40-60$ & 22.000 & 5.500 & 6 \\
\hline $\begin{array}{c}\text { (3) - } 80 \text { bar - } \\
480^{\circ} \mathrm{C} \text { TG } \\
\text { Condensação }\end{array}$ & Ano todo & 340 & $100-150$ & 54.000 & 7.200 & 16 \\
\hline $\begin{array}{l}\text { (4) - BIG / GT } \\
\text { gaseificação } \\
\text { da biomassa }\end{array}$ & Ano todo & $<340$ & $200-300$ & 110.000 & 14.500 & 32 \\
\hline
\end{tabular}

Obs.: Consumo nacional de energia elétrica $=342 * 10^{3} \mathrm{GWh} /$ ano (2003-BEN 2004)

Moagem anual de 360 milhões de toneladas de cana-de-açúcar (safra 2003/04)

Fonte: Centro de Tecnologia Canavieira - CTC 
Paes (2005) relatou que o trabalho efetuado pelo Centro de Tecnologia Canavieira CTC apurou que o Brasil produziu anualmente mais de 40 milhões de toneladas de palhiço, mas como o resíduo tem a função de proteger o solo, acredita-se que apenas a metade poderia ser usada para a geração de energia. O melhor seria encontrar o equilíbrio, o palhiço é importante para gerar energia, mas é importante para o solo também. Então, o melhor seria deixar a metade do total do palhiço no local e a outra parte se utilizaria na indústria. Para isso, no entanto, é necessário que para toda a produção de cana-de-açúcar no país seja eliminada a prática de queima do palhiço.

Ainda relativo ao projeto $\mathrm{BRA} / 96 / \mathrm{G} 31$ (geração de energia por biomassa, desenvolvido pelo CTC - Centro de Tecnologia Canavieira, com o apoio do PNUDPrograma das Nações Unidas para o Desenvolvimento), Paes (2007), considerou três alternativas de coleta de palhiço, e os resultados das respectivas eficiências de separação do palhiço:

Alternativa 1- separação do palhiço no campo, com $88 \%$ de efetividade;

Alternativa 2- separação na indústria com $95 \%$ de efetividade e

Alternativa 3- separação parcial no campo e na indústria com $71 \%$ de efetividade.

A Tabela 3 demonstra a disponibilidade de biomassa seca para safra de 388 milhões de toneladas de cana-de-açúcar e as Figuras 1, 2 e 3 os fluxogramas das alternativas de recolhimento de palhiço.

Tabela 3 - Disponibilidade de biomassa seca de resíduos da colheita da cana-de-açúcar no Brasil

\begin{tabular}{ccccc}
\hline Local & $\begin{array}{c}\text { Biomassa } \\
\text { produzida } \\
\text { (milhões t) }\end{array}$ & Alternativa 1 & Alternativa 2 & Alternativa 3 \\
\hline São Paulo & 32,2 & 28,3 & 30,6 & 22,9 \\
\hline Centro-Sul & 46,1 & 34,5 & 37,2 & 27,8 \\
\hline Norte-Nordeste & 8,3 & 3,6 & 3,9 & 2,9 \\
\hline Brasil & 54,4 & 38,1 & 41,1 & 30,7 \\
\hline
\end{tabular}

Obs.: Bagaço excedente Brasil = 3,4 milhões de t. Base safra 2004/05 - 388 milhões de $t$ de cana-de-açúcar

Fonte: Centro de cultura canavieira - CTC 


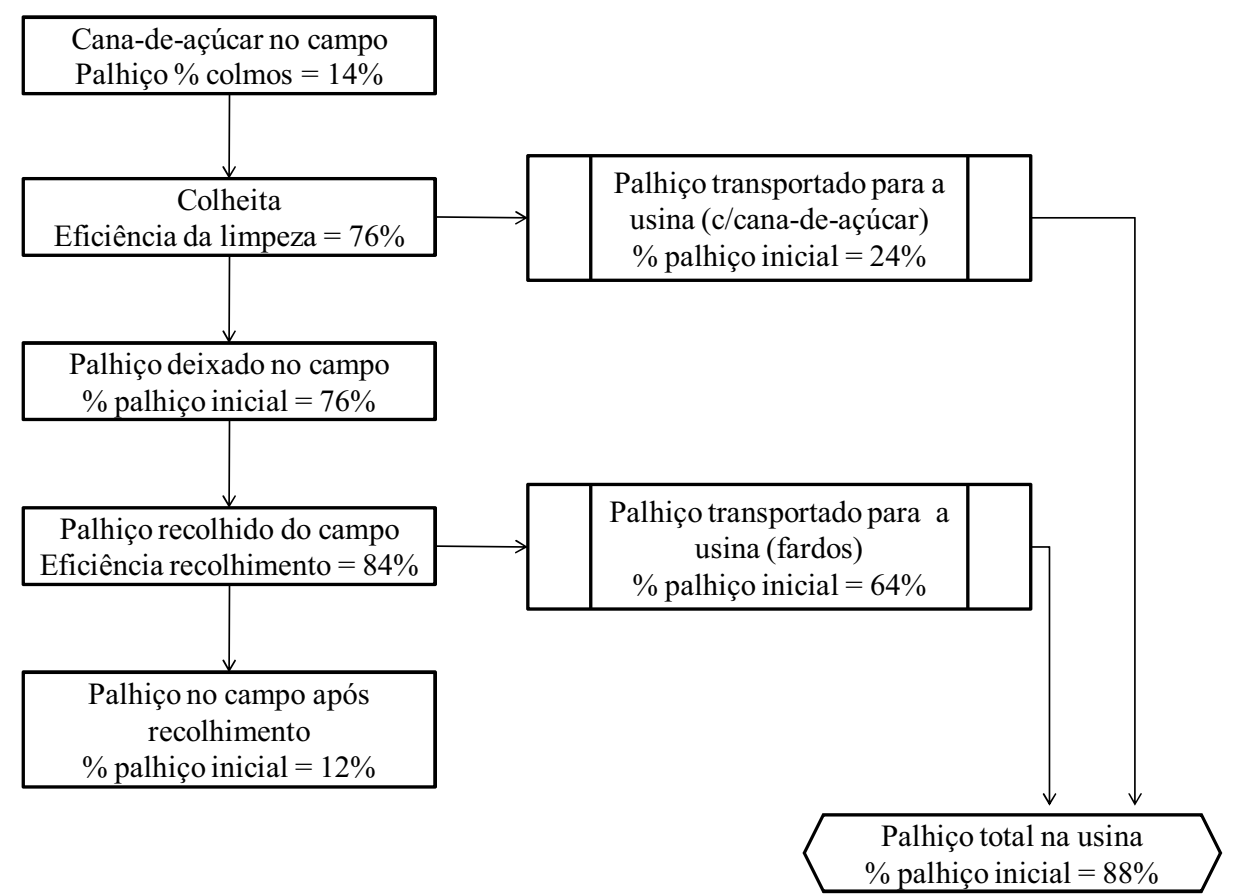

Figura 1- Fluxograma mostrando a separação de palhiço no campo, de acordo com a alternativa 1 e os resultados percentuais por etapas.

Fonte: CTC - Centro de Tecnologia Canavieira

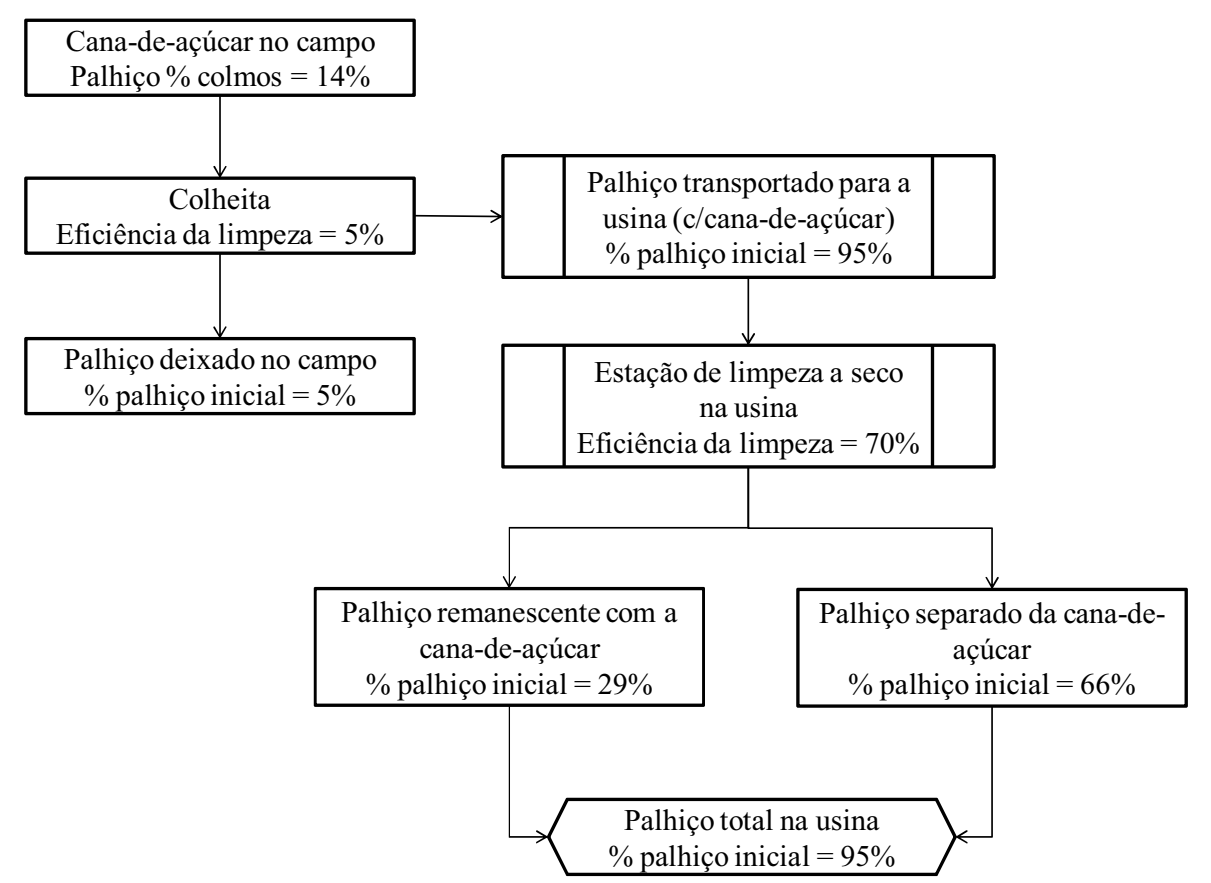

Figura 2 - Fluxograma mostrando a separação de palhiço na indústria, de acordo com a alternativa 2 e os resultados percentuais por etapas.

Fonte: CTC - Centro de Tecnologia Canavieira 


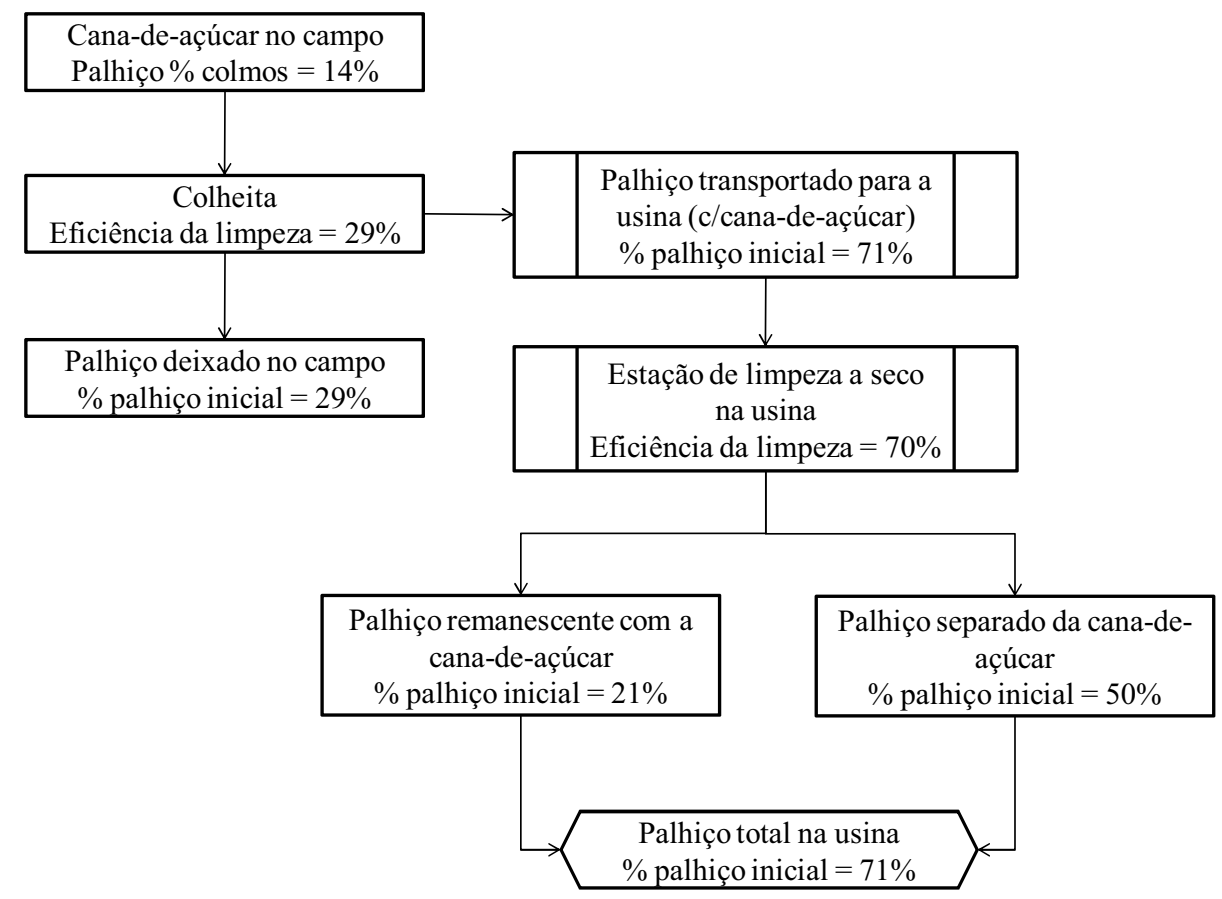

Figura 3 - Fluxograma mostrando a separação parcial de palhiço no campo e na indústria, de acordo com a alternativa 3 e os resultados percentuais por etapas.

Fonte: CTC - Centro de Tecnologia Canavieira

O uso do palhiço como combustível poderá ser aplicado nas caldeiras existentes que usam o bagaço como combustível; ele deverá ser utilizado em mistura com o bagaço devendo antes ser picado ou desfibrado para que não obstrua o sistema de alimentação das caldeiras. Sua composição físico-química é muito parecida com a do bagaço, diferenciando-se em densidade e umidade. Preconiza-se que seu percentual de mistura seja mantido constante para que não haja bruscas alterações físicas do combustível da caldeira.

Na Tabela 4 é demonstrada a comparação de seu poder calorífico com o do bagaço e na Tabela 5, a caracterização físico-química palhiço/bagaço.

Tabela 4 - Comparação de poder calorífico - palhiço e bagaço

\begin{tabular}{lcccc}
\hline $\begin{array}{c}\text { PCS* } \\
(\mathbf{b s}) \\
\mathbf{M J} / \mathbf{k g}\end{array}$ & $\begin{array}{c}\text { Umidade } \\
\mathbf{( \% )}\end{array}$ & $\mathbf{M J} / \mathbf{k g}$ & $\mathbf{K c a l} / \mathbf{k g}$ \\
\hline Palhiço & 17,4 & 15 & 13,3 & 3.170 \\
\hline Bagaço & 18,1 & 50 & 7,2 & 1.720 \\
\hline
\end{tabular}

*PCS $=$ Poder Calorífico Superior **PCI $=$ Poder Calorífico Inferior

Fonte: CTC - Centro de Tecnologia Canavieira 
Tabela 5 - Propriedades físico-química do palhiço e do bagaço da cana-deaçúcar/caracterização palhico-bagaço

\begin{tabular}{lcccccc}
\hline Imediata (\%) & Umidade & Cinzas & Carbono Fixo & Voláteis & & \\
\hline Palhiço & 29,40 & 3,90 & 12,80 & 83,30 & & \\
\hline Bagaço & 50,20 & 2,20 & 18,00 & 79,80 & $\mathbf{S}$ & $\mathbf{C l}$ \\
\hline Elementar (\%) & $\mathbf{C}$ & $\mathbf{H}$ & $\mathbf{N}$ & $\mathbf{O}$ & 0,10 & 0,20 \\
\hline Palhiço & 46,00 & 6,20 & 0,60 & 43,00 & 0,02 \\
\hline Bagaço & 44,60 & 5,80 & 0,60 & 44,50 & 0,10 & 0,02 \\
\hline Cinzas (g/kg) & $\mathbf{P}_{\mathbf{2}} \mathbf{O}_{\mathbf{5}}$ & $\mathbf{K}_{\mathbf{2}} \mathbf{O}$ & $\mathbf{C a O}$ & $\mathbf{M g O}$ & $\mathbf{F e}_{\mathbf{2}} \mathbf{O}_{\mathbf{3}}$ & $\mathbf{A l}_{\mathbf{2}} \mathbf{O}_{\mathbf{3}}$ \\
\hline Palhiço & 0,90 & 6,50 & 4,40 & 2,10 & 0,80 & 2,90 \\
\hline Bagaço & 0,50 & 1,70 & 0,70 & 0,50 & 2,30 & 2,30 \\
\hline
\end{tabular}

Fonte - CTC - Centro de Tecnologia Canavieira

A estimativa realizada pelo Centro de Tecnologia Canavieiro - CTC da Coopersucar (2005) é de que a quantidade de palhiço por hectare é igual a 14,4 t de matéria seca e equivale a $14 \%$ dos colmos da cana-de-açúcar, logo para uma produção brasileira de 350 milhões de toneladas de cana-de-açúcar existe um potencial de coleta de 49 milhões de toneladas de palhiço matéria seca. Paes (2005) demonstrou por meio de pesquisas essa potencial quantidade de palhiço, conforme pode ser visto na Figura 4 e nas Tabelas 6 e 7 .

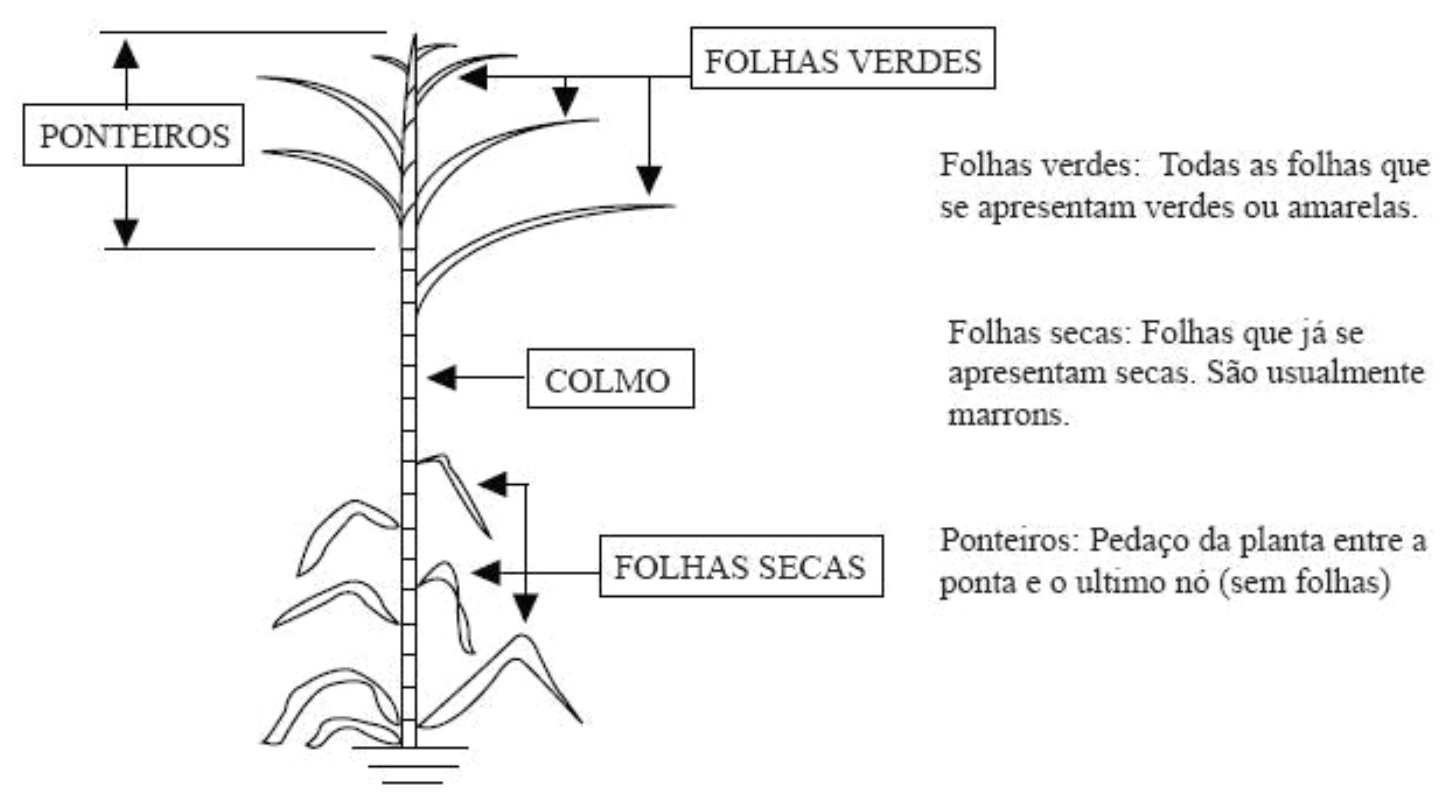

Figura 4 - Caracterização do palhiço da cana-de-açúcar. Fonte: CTC - Centro de Tecnologia Canavieira (2005) 
Tabela 6 - Estimativa da quantidade de palhiço em diversas variedades de cana-de-açúcar

\begin{tabular}{lcccc}
\hline \multicolumn{1}{c}{ Fonte } & Variedade & $\begin{array}{c}\text { Resíduos } \\
\text { (MS, em } \\
\text { t/ha) }\end{array}$ & $\begin{array}{c}\text { Produção } \\
\text { (t/ha) }\end{array}$ & $\begin{array}{c}\text { Resíduos / } \\
\text { produção } \\
\text { (\%) }\end{array}$ \\
\hline RÍPOLI et al. (1991) & NA56-79 & 13,34 & 72,53 & 18,40 \\
\hline TRIVELINI et al. (1996) & SP70-1143 & 11,70 & 70,00 & 16,70 \\
\hline RÍPOLI et al. (1991) & SP70-1143 & 10,97 & 88,27 & 12,40 \\
\hline RÍPOLI et al. (1991) & SP70-1284 & 7,44 & 77,20 & 9,70 \\
\hline RÍPOLI et al. (1991) & RB72454 & 19,02 & 83,10 & 22,90 \\
\hline RÍPOLI et al. (1991) & SP71-1406 & 14,42 & 75,64 & 19,10 \\
\hline FURLANI NETO et al. (1997) & SP71-1406 & 13,51 & 68,58 & 19,70 \\
\hline MOLINA JR et al. (1991) & SP71-6163 & 14,18 & 79,52 & 17,83 \\
\hline RÍPOLI et al. (1991) & SP71-6163 & 11,70 & 74,92 & 15,60 \\
\hline FURLANI NETO et al. (1997) & SP71-6163 & 24,32 & 82,45 & 29,50 \\
\hline & Média $\pm \mathbf{\sigma}$ & $\mathbf{1 4 , 0 6} \pm$ & $\mathbf{7 7 , 2 2} \pm$ & $\mathbf{1 8 , 1 8 \pm}$ \\
\hline & & $\mathbf{4 , 4 2}$ & $\mathbf{5 , 8 8}$ & $\mathbf{5 , 1 8}$ \\
\hline
\end{tabular}

Fonte: CTC - Centro de Tecnologia Canavieira (2005)

Tabela 7- Resultado da pesquisa do potencial de palhiço em diversas variedades de cana-deaçúcar.

\begin{tabular}{ccccc}
\hline Variedade & Estágio Corte & $\begin{array}{c}\text { Produtividade } \\
\text { colmos (t/ha) }\end{array}$ & $\begin{array}{c}\text { Palhiço (MS) } \\
\text { (t/ha) }\end{array}$ & $\begin{array}{c}\text { Relação } \\
\text { palhiço/colmos }\end{array}$ \\
\hline SP79-1011 & $1^{\circ} \mathrm{C}$ & 119,96 & 17,80 & $15,0 \%$ \\
\cline { 2 - 5 } & $3^{\circ} \mathrm{C}$ & 91,46 & 15,00 & $16,0 \%$ \\
\cline { 2 - 5 } & $5^{\circ} \mathrm{C}$ & 84,21 & 13,70 & $16,0 \%$ \\
\cline { 2 - 5 } & Média & $\mathbf{9 8 , 5 4}$ & $\mathbf{1 5 , 5 0}$ & $\mathbf{1 5 , 7 \%}$ \\
\hline SP80-1842 & $1^{\circ} \mathrm{C}$ & 135,76 & 14,60 & $11,0 \%$ \\
\cline { 2 - 5 } & $3^{\circ} \mathrm{C}$ & 100,49 & 12,60 & $13,0 \%$ \\
\cline { 2 - 5 } & $5^{\circ} \mathrm{C}$ & 91,61 & 10,50 & $11,0 \%$ \\
\cline { 2 - 5 } Média & $\mathbf{1 0 9 , 2 8}$ & $\mathbf{1 2 , 6 0}$ & $\mathbf{1 1 , 5 \%}$ \\
\hline RB72 454 & $1^{\circ} \mathrm{C}$ & 134,26 & 17,20 & $13,0 \%$ \\
\cline { 2 - 5 } & $3^{\circ} \mathrm{C}$ & 99,76 & 14,90 & $15,0 \%$ \\
\cline { 2 - 5 } & $5^{\circ} \mathrm{C}$ & 78,16 & 13,60 & $17,0 \%$ \\
\cline { 2 - 5 } & Média & $\mathbf{1 0 4 , 0 6}$ & $\mathbf{1 5 , 2 0}$ & $\mathbf{1 4 , 6 \%}$ \\
\hline Média $\mathbf{G e r a l}$ & $\mathbf{1 0 3 , 9 6}$ & $\mathbf{1 4 , 4 2}$ & $\mathbf{1 4 , 0 \%}$ \\
\hline
\end{tabular}

Fonte: Centro de Tecnologia Canavieira - CTC

O setor sucroalcooleiro, por sua vez, foi convocado pelo governo, a participar do Programa de Incentivo às Fontes Alternativas de Energia Elétrica - PROINFA 
(2002) e Leilões de Energia Nova e Leilões de Energia de Reserva na forma de bioeletricidade (2005 e 2007), através do uso da biomassa, vislumbrando no uso do palhiço, um combustível complementar ao bagaço da cana-de-açúcar, com possibilidades de aumentar sua capacidade de produção de vapor e consequentemente, também o seu processo de cogeração e comercialização de energia elétrica excedente.

O Brasil é a principal região do mundo para a produção de biomassa, caracterizado pela fartura de água, terra, sol e domínio da tecnologia. Situado, predominantemente, na faixa tropical e subtropical do planeta, entre o Trópico de Câncer, e o Trópico de Capricórnio, está localizado na região mais propensa à produção de biomassa. Dentre os países situados nessa faixa, o Brasil é um dos que apresenta maior potencial de produção agrícola. De fato, na África e Austrália a maior parte do território é caracterizada por área desértica, portanto, economicamente inviáveis para a produção, com base no conhecimento tecnológico atual. Adicionalmente, o Brasil, com sua dimensão continental e diversidade geográfica, apresenta diversidade de clima e exuberância de biodiversidade e detém um quarto das reservas superficiais e sub-superficiais de água doce do mundo. $\mathrm{Na}$ Figura 5 pode ser verificada essa condição.

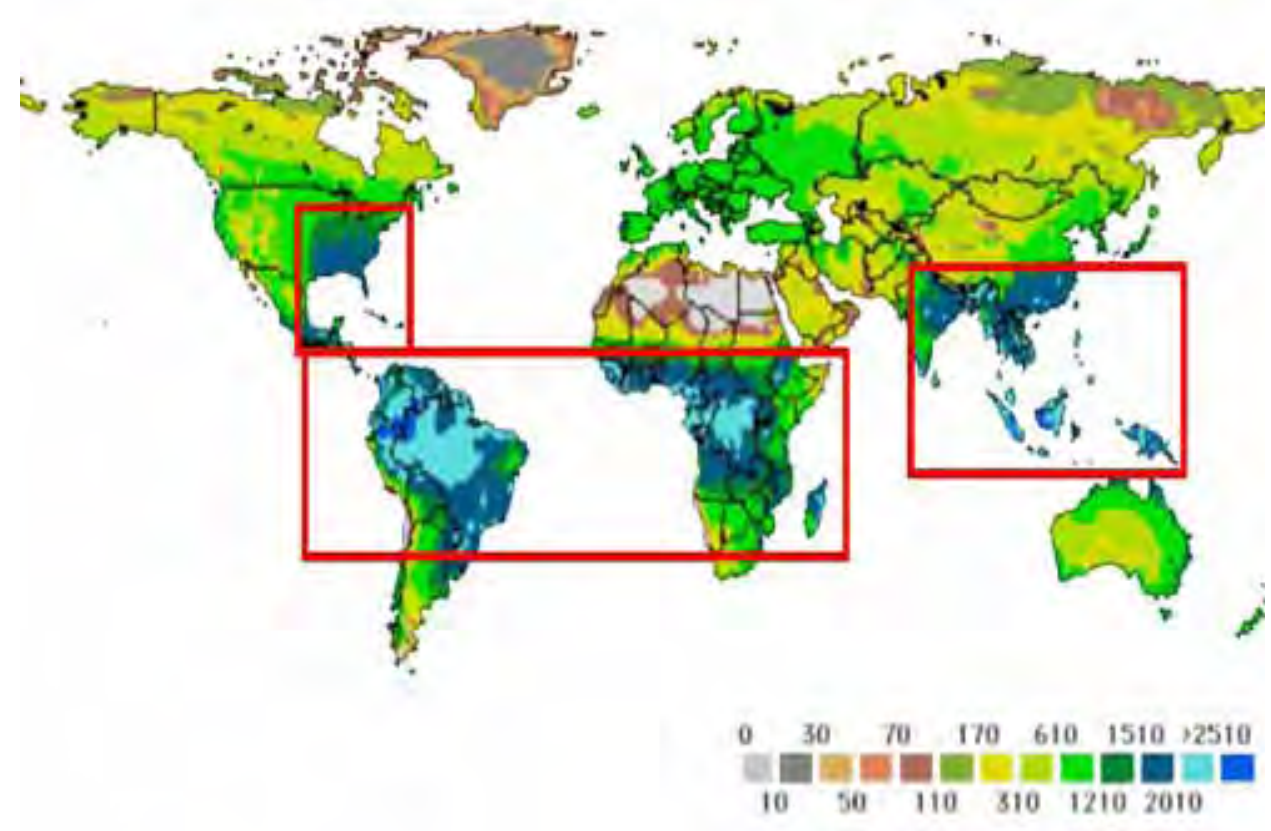

Figura 5 - Potencial de produção de biomassa no mundo em gms $/ \mathrm{m}^{2} /$ ano (grama de matéria $\left.\mathrm{seca} / \mathrm{m}^{2} / \mathrm{ano}\right)$.

Fonte - Cogensp (2008) 
Embora conte com uma atividade agrícola bastante intensa, o Brasil dispõe, ainda, de vasta extensão de terra agriculturável disponível, sem prejudicar áreas de florestas e de preservação ambiental. Já a produção de cana-de-açúcar no Brasil se concentra em áreas onde não existem riscos de desmatamentos (Figura 6) e em casos como do Estado de São Paulo, em áreas de zoneamento definidos e sustentáveis atendendo a itens de questionamento mundial sobre a produção de bicombustíveis sem afetar a agricultura de alimentos.

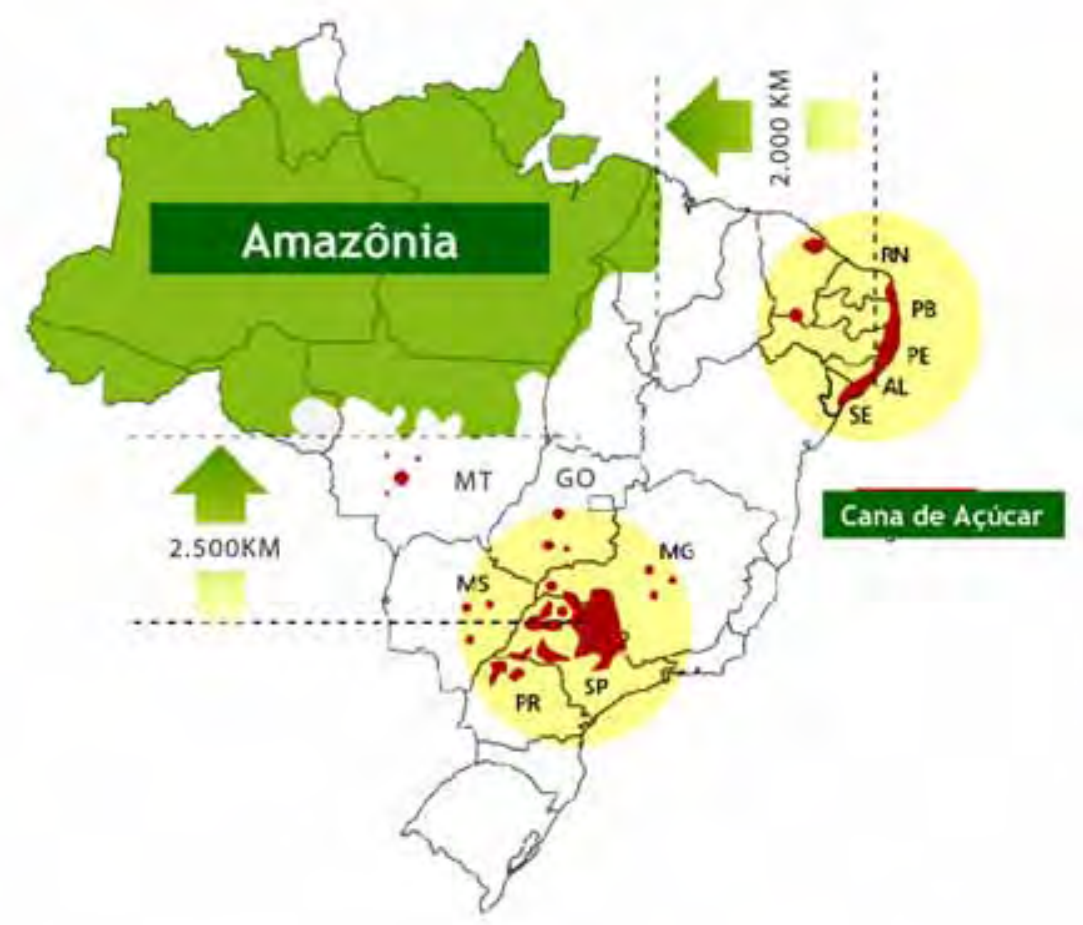

Figura 6 - Áreas de produção de cana-de-açúcar no Brasil. Fonte: Cogensp

A expansão das novas indústrias sucroalcooleiras está se dando na região centro-oeste do país e noroeste do Estado de São Paulo (Figura 7). As empresas do nordeste do país estão migrando desde o inicio desta década para o centro-oeste objetivando redução de seus custos com plantações em terras de melhor produtividade agrícola. 
O Estado de São Paulo tem hoje praticamente esgotado os recursos hídricos para geração de energia elétrica e tem seu grau de dependência elétrica crescente. Para o ano de 2015, essa importação de energia é projetada em 65,5\% em relação a 49,0\% de 2007, isso significa acréscimo de 13.585 MW na demanda requerida. Logo o governo estabeleceu através do decreto 51736 de 04/04/07 o Plano de Bioenergia no Estado de São Paulo como estratégia para redução dessa dependência.

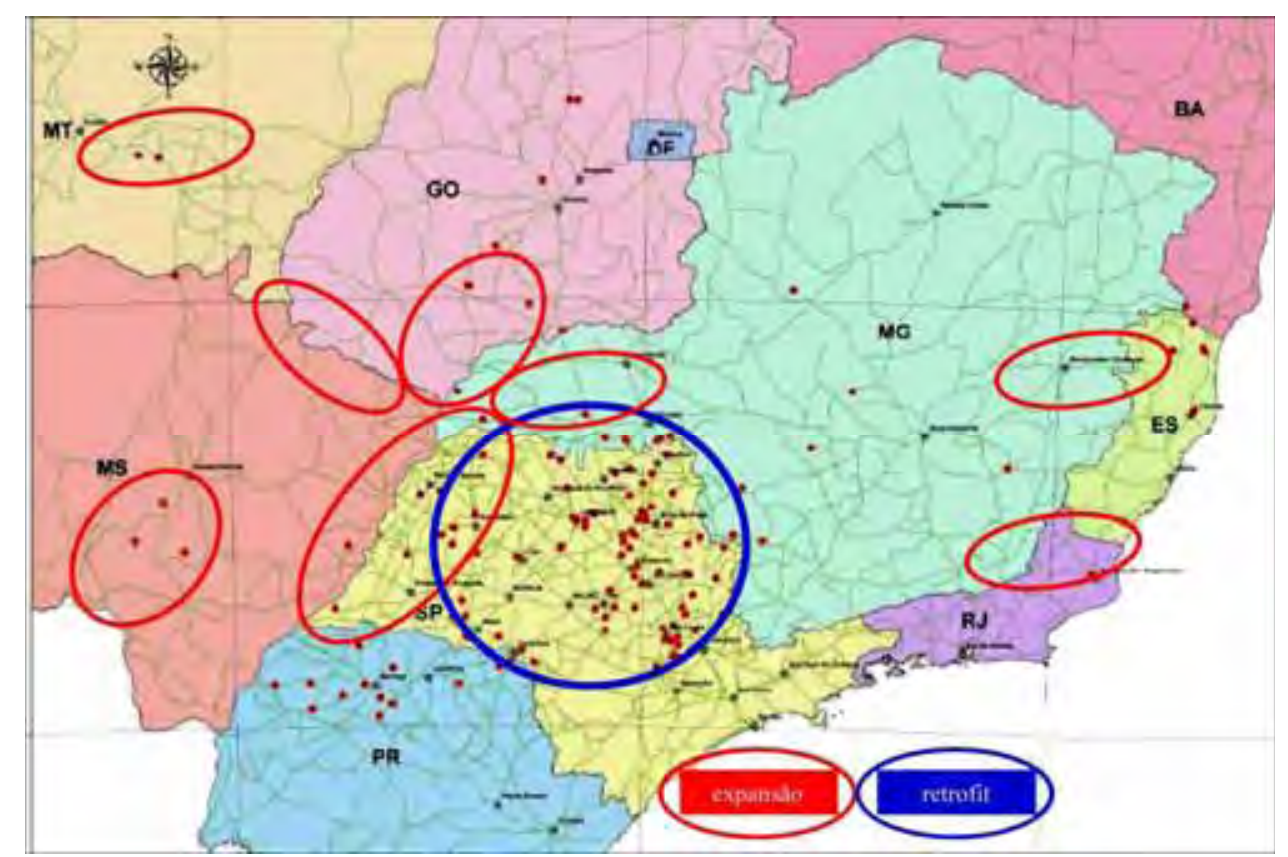

Figura 7 - Mapa da expansão da indústria da cana-de-açúcar no Brasil. Fonte: Cogensp

Economicamente a bioeletricidade se viabiliza como complementar no período de maio a novembro (período seco) onde os custos marginais de operação são mais elevados. Porém deve ser considerado que o potencial de bioeletricidade apresentado compreende o uso do bagaço e do palhiço da cana-de-açúcar como combustível das caldeiras.

Já o MME - Ministério das Minas e Energia divulgou o Balanço Estático de Energia Elétrica -MME 2007, onde são requeridos 4.200 MW de bioeletricidade até 2015 para equilibrar a demanda e a oferta de energia elétrica, conforme pode ser observado pela Figura 8. 


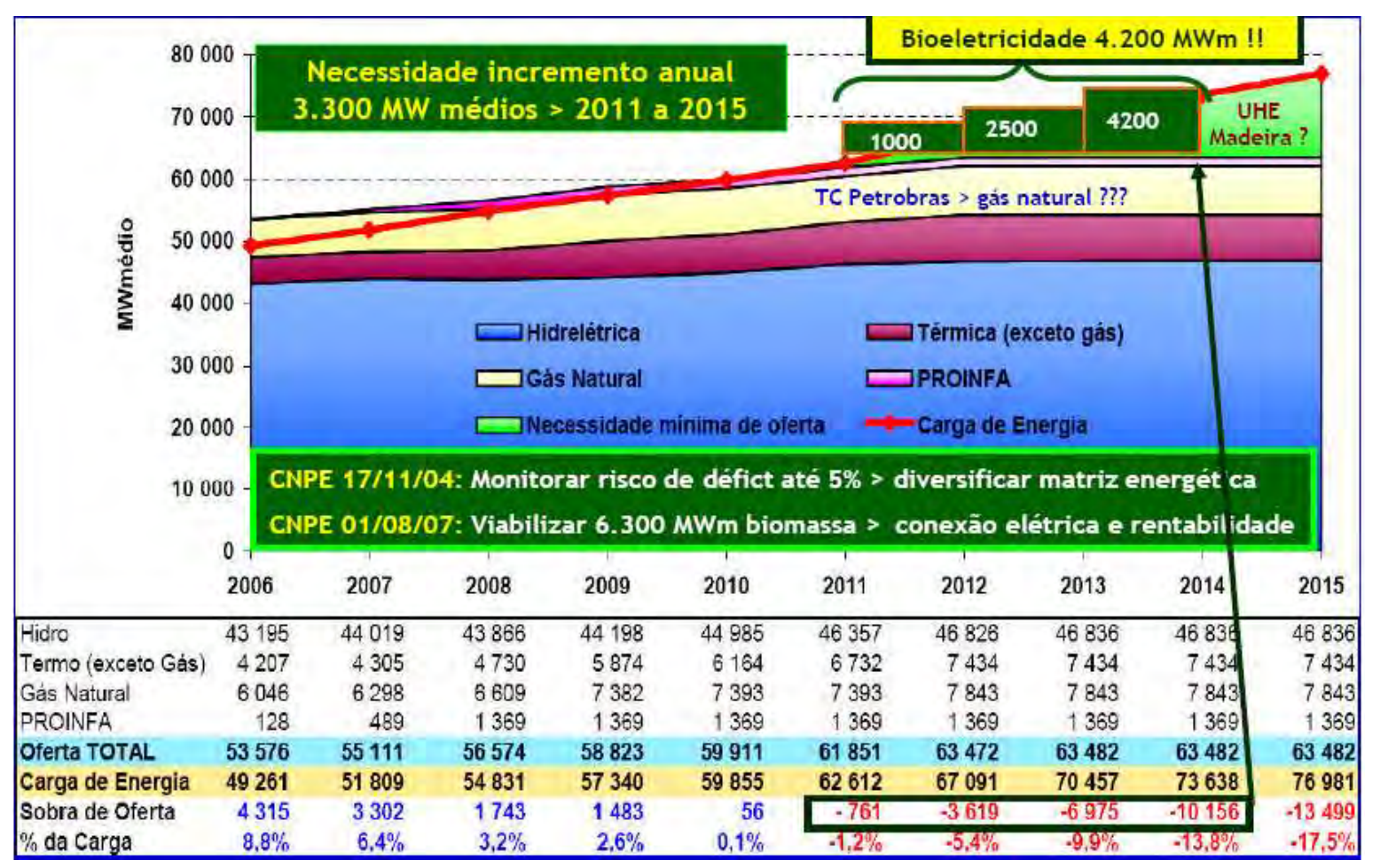

Figura 8 - Balanço Estático de Energia Elétrica - MME 2007.

Fonte: Cogensp (2007)

Essa demanda de energia elétrica que deverá ser suprida pela bioeletricidade está potencializada na Tabela 8 , com dados cadastrados na COGEN- SP, Associação Paulista de Cogeração de Energia (2009).

Tabela 8 - Potencial de bioeletricidade estimado pelo número de empreendimentos cadastrados nos leilões de energia realizados em 2008 (A3, A5 e Energia de Reserva). Fonte: Cogensp/Semana Franco-Brasileira de biocombustíveis (2008)

\begin{tabular}{|c|c|c|c|c|c|c|c|c|c|c|}
\hline \multirow{2}{*}{$\mathbf{U F}$} & \multirow{2}{*}{$\begin{array}{c}\text { № } \\
\text { cadastrados }\end{array}$} & \multirow{2}{*}{$\begin{array}{l}\text { Potência } \\
\text { MW }\end{array}$} & \multicolumn{8}{|c|}{ Ano } \\
\hline & & & 2008 & 2009 & 2010 & 2011 & 2012 & 2013 & 2014 & 2015 \\
\hline \multirow{2}{*}{ SP } & \multirow{2}{*}{104} & Instalada & 0 & 2707 & 4945 & 5607 & 5895 & 6068 & 6239 & 6386 \\
\hline & & Exportada & 602 & 1471 & 3392 & 3840 & 4094 & 4233 & 4350 & 4470 \\
\hline \multirow{2}{*}{$\mathrm{GO}$} & \multirow{2}{*}{39} & Instalada & 220 & 830 & 1694 & 2344 & 2775 & 3051 & 3105 & 3105 \\
\hline & & Exportada & 92 & 502 & 1110 & 1521 & 1850 & 2085 & 2142 & 2142 \\
\hline \multirow{2}{*}{ MS } & \multirow{2}{*}{34} & Instalada & 40 & 368 & 1427 & 2050 & 2554 & 2837 & 2967 & 2967 \\
\hline & & Exportada & 0 & 204 & 919 & 1339 & 1679 & 1889 & 1978 & 1978 \\
\hline \multirow{2}{*}{ MG } & \multirow{2}{*}{33} & Instalada & 235 & 488 & 1117 & 1749 & 1949 & 2161 & 2359 & 2381 \\
\hline & & Exportada & 90 & 229 & 624 & 1058 & 1266 & 1426 & 1582 & 1604 \\
\hline \multirow{2}{*}{ Total } & \multirow{2}{*}{210} & Instalada & 1955 & 4393 & 9183 & 11749 & 13173 & 14116 & 14670 & 14839 \\
\hline & & Exportada & 784 & 2406 & 6045 & 7757 & 8889 & 9633 & 10051 & 10193 \\
\hline
\end{tabular}




\subsection{Manejo do palhiço de cana-de-açúcar utilizando a queimada.}

Além da razão energética, a prática de queima do palhiço a fim de facilitar o corte manual da cana-de-açúcar, apresenta sérias agressões ao meio-ambiente.

Conforme Resende (2005), as discussões a respeito da queima dos canaviais vêm de muito tempo e dividem opiniões de pesquisadores em todo o mundo, desde os primórdios de seu uso, até os dias de hoje. Afirmou ainda, que é bem provável que a razão deste fato seja decorrente da diversidade de condições em que cada pesquisa vem sendo realizada, uma vez que o comportamento da cana-de-açúcar dentro dessas experiências é função de um grande número de fatores como o clima, a temperatura, o local e a intensidade da queima, a variedade da cana, seu estado de sanidade e de maturidade, o sistema de cultivo e os tratos culturais adotados, além de outros que podem ser considerados secundários e/ou complementares. Resende (2005) citou Valsechi que relatou em 1951, o trabalho de Boname que, em 1888 já explicitava as divergências sobre o efeito da queima: "a fim de se executar os trabalhos necessários ao cultivo das socas, sem o incomodo causado pelas folhas que embaraçam o chão, existe um meio radical: é o ateamento de fogo. Esta prática apresenta certas vantagens e inconvenientes, predominando ora as primeiras, ora o segundo em função das condições locais. Se o fogo, instantaneamente limpa o solo, facilitando a marcha dos instrumentos aratórios, também destrói, ao mesmo tempo a matéria orgânica que poderia ser transformada em húmus. Dessa queima resultam cinzas alcalinas que agem sobre a vegetação da cana mais prontamente do que se estivessem sob a forma orgânica. Entretanto o efeito de sua duração é curto. Pela queima desaparecem as vantagens da cobertura que mantinha o solo naturalmente fresco".

Ainda Resende (2005) relatou que em 1919, Baldwin, em estudos no Hawai, afirmava que a prática da queima em áreas pequenas era muito dispendiosa devido ao tempo gasto fazendo aceiros e controlando o fogo durante a queimada, e que em 1923 Dominguez, em seus estudos, encontrou perdas de peso, inversão de sacarose, açúcares redutores e acidez, além da exsudação com maior intensidade para cana queimada, que se tornou mais grave após o quarto dia. 
Relatou Resende (2005) que Walcott, em 1923, avaliando 50000 plantas de canas-de-açúcar em diferentes canaviais de Porto Rico, constatou que, em todos os pontos da Ilha, e nas mesmas variedades, sob precipitação similar, a infestação por broca aumentava de 5 a $10 \%$ onde se queimava o palhiço. Este trabalho, na época, foi surpreendente pelo fato da queima ser usada justamente para o controle da broca e que Valsechi em 1951, comentando este trabalho, afirmava que em alguns de seus estágios vitais, a broca não é destruída pelo fogo, ao contrário dos ovos de seu parasita, Tricchogramma minutum. Resende (2005) afirmou que desta forma, este autor em outro trabalho, (Walcott em 1923), concluiu que o palhiço e os resíduos da cana-de-açúcar não deveriam ser queimados depois do corte dos colmos (na época, a cana-de-açúcar era colhida crua, pois se acreditava que a queima prejudicava muito a fabricação do açúcar, e o palhiço era queimado sobre o solo após a retirada da cana-de-açúcar), pois este processo possibilita o aumento da infestação da broca uma vez que os ovos de seus parasitos são destruídos.

Rosenfeld (1926), citado por Resende (2005), relatou no Peru, que é notável que os vales onde não se pratica a queima da cana-de-açúcar são os únicos lugares onde não se encontra a broca. Conclui-se daí que o fogo destrói os inimigos naturais da broca. E que para outro pesquisador Cairo (1924), a queima do palhiço, após o corte da cana-de-açúcar, faz com que as socas brotem com mais vigor, enquanto que Bayama em 1924 afirmava que esta prática é um erro, uma vez que destrói a matéria orgânica.

Resende (2005) citou Pestana que já em 1925, lamentava que ainda perdurasse entre os lavradores da época, a mentalidade antiquada, antieconômica e prejudicial da queima do palhiço, depois do corte dos canaviais, somente aconselhando o uso do fogo quando o canavial estava muito parasitado. Outro aspecto que estimulou a queima no passado é o de que a manutenção do palhiço no sistema por um tempo mais longo poderia provocar a morte da cana em caso de incêndio após sua rebrota, discussão que vem sendo repetida erroneamente até hoje, com o crescimento da colheita de cana crua mecanizada.

Resende (2005) citou Rosenfeld que em 1941, relatou do ponto de vista agrícola, a queima da cana-de-açúcar representa perda de húmus, entretanto, sendo o corte da cana-de-açúcar não queimada mais caro do que o da queimada ficou-se na dependência econômica destas operações: pagar mais pelo corte ou perder húmus. Resende 
(2005), também citou Caminha Filho que em 1942, afirmou que o palhiço enleirado entre as fileiras de cana-de-açúcar, decompõe-se lentamente, fornecendo matéria orgânica e conservando a umidade ao solo, evitando o crescimento de ervas daninhas e auxiliando o desenvolvimento de insetos parasitos da broca.

Spencer (1967) relatou que a cana-de-açúcar não é danificada pelo fogo, porém deve-se cortá-la imediatamente porque se evitam assim perdas por deterioração, que se aceleram, ainda mais, no caso de chuva. Na maior parte dos contratos em Cuba, o fabricante recebe cana-de-açúcar queimada sem desconto no preço, durante os 5 primeiros dias, porém, em caso de chuvas, pode rejeitá-las.

Resende (2005) concluiu que durante a primeira metade do século XX, as preocupações quanto à queima do palhiço na cultura de cana-de-açúcar, seja ela feita antes ou depois da colheita, tinha por principais objetivos controlar a incidência de pragas e eliminar os restos culturais para renovação do canavial. No entanto, já nesta época, a maior preocupação era com a deterioração da cana no que diz respeito às suas qualidades tecnológicas e industriais. A redução da matéria orgânica do solo também já era preocupação dos pesquisadores da época em todo o mundo assim como as preocupações com o custo da colheita.

O que se pode concluir é que muitas das dúvidas e divergências quanto ao impacto da queima em prejuízo do solo já existiam desde àquela época e parecem persistir até hoje, justamente por falta de uma avaliação a longo prazo desta prática. Outra ressalva que deve ser feita é que naquela época a falta de maquinário e tecnologia apropriados limitavam as práticas de manejo; hoje, este argumento já não é mais válido e, alternativas conservacionistas são possíveis e viáveis desde que estudos relevantes possam realmente confirmar sua eficiência, trazendo maior tranqüilidade para o agricultor, que pode então planejar a mudança gradual de seu sistema de manejo.

A prática da queima do palhiço da cana-de-açúcar a fim de facilitar o corte, também apresenta inúmeros problemas de agressão ao meio ambiente, sendo objeto de reclamações junto ao Ministério Público Estadual. Paes (2005) destaca que a queima do palhiço da cana-de-açúcar é pratica usual em quase todos os 97 países que a produzem. Essa queima tem por objetivo aumentar a segurança do trabalhador e o rendimento do corte pela 
eliminação do palhiço e folhas secas. Inúmeros trabalhos foram realizados com relação à ocorrência de doenças respiratórias crônicas em polos sucroalcooleiros, mas os resultados foram de que os mesmos riscos de ocorrências dessas doenças foram encontrados em municípios considerados como estância climática e onde não há produção de cana-de-açúcar. Ainda Paes (2005) citou que no Hawai, investigação feita pelo Instituto Nacional Americano para a Saúde e Segurança Ocupacional - NIOSH, não conseguiu comprovar danos à saúde causados pela fuligem da queima da cana-de-açúcar e que apesar de vários trabalhos não apresentarem relação direta das queimadas com prejuízos à saúde, deve-se observar que qualquer tipo de queima de alguma forma tem efeito sobre o meio ambiente, principalmente quando realizada de forma incompleta, caso das queimadas. Além disso, na queima da canade-açúcar existe o incomodo causado pela emissão de particulados (carvãozinho) e alguns riscos para áreas como redes elétricas e rodovias.

\subsection{Programa de eliminação de queimadas no Estado de São Paulo}

As queimadas, objeto de reclamações junto ao Ministério Publico Estadual, resultou em dispositivo legal através da Lei 11.241 de 19 de setembro de 2002 e Decretos 47.700 de 11 de março de 2003 e 49.391 de 21 de fevereiro de 2005, eliminando-as gradativamente.

O cronograma definido no artigo $2^{\circ}$ do Decreto 47.700 estabelece que, para as plantações em áreas, mecanizáveis iguais ou superiores a 150 hectares, o prazo limite para eliminação da queima do palhiço é o ano de 2021. A eliminação, da queima do palhiço, nas áreas inferiores a 150 hectares e nas áreas não mecanizava deverá ocorrer entre 2011 e 2031.

Nas áreas cultivadas em solos de maior declividade o decreto prevê o término da queima em 30 anos, em 2031. Uma vez que estas áreas não permitem a mecanização no corte e o custo da colheita manual da cana-de-açúcar sem queima reduziria sua competitividade, é razoável esperar que ocorram deslocamentos de áreas produtoras para regiões com melhores características topográficas. É também provável que haja uma busca de aumento de produção nas áreas mecanizáveis através da incorporação de novas tecnologias no processo produtivo, segundo o que relatou Paes (2005). 
A Figura 9 apresenta em gráfico o Programa de Eliminação de Queimadas

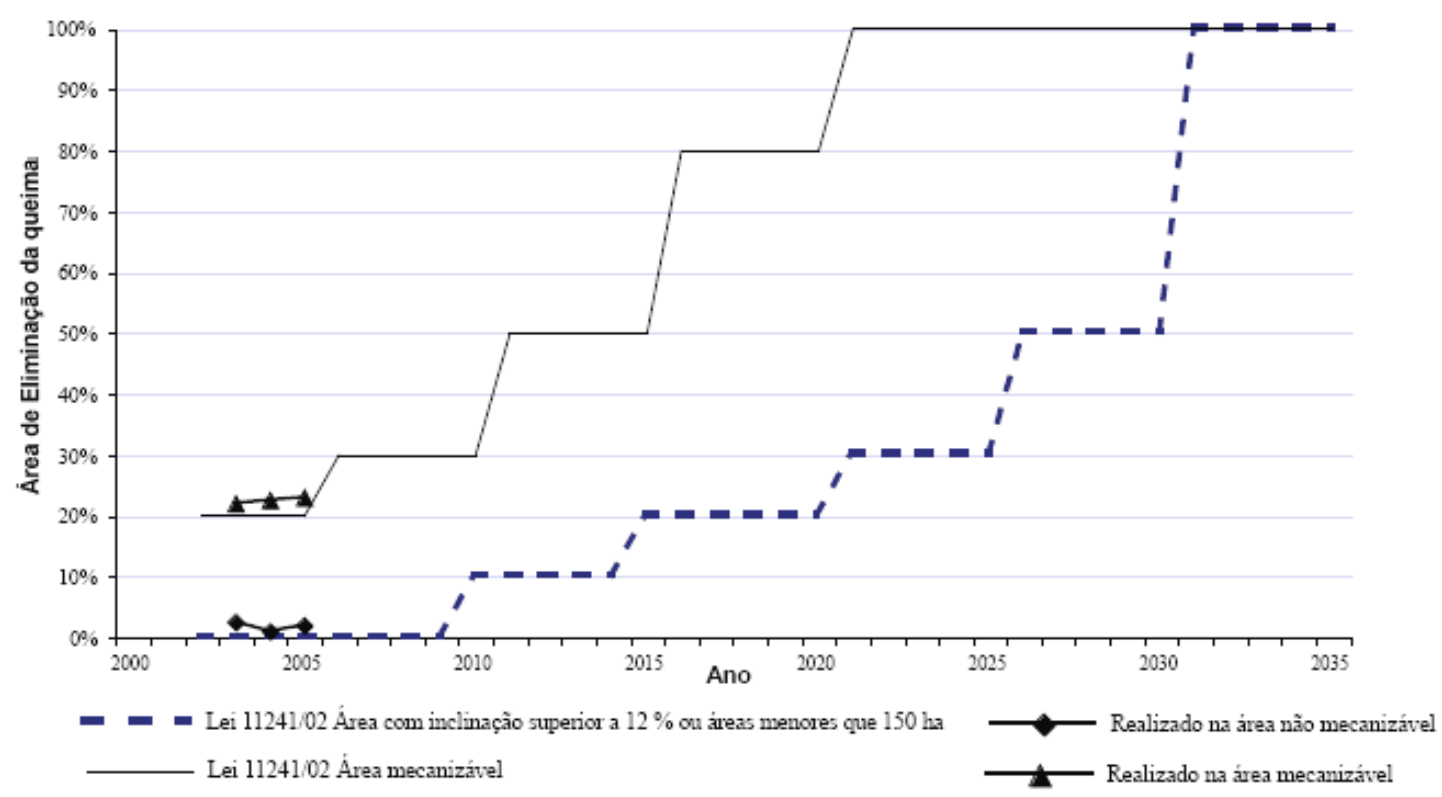

Figura 9 - Cronograma do Programa de Eliminação de Queimadas em São Paulo Fonte: Secretaria do Meio Ambiente do Estado de São Paulo

Em antecipação aos fatos, em 04 de junho de 2007 houve a assinatura do Protocolo de Cooperação celebrado entre, o Governo do Estado de São Paulo, a Secretaria do Meio Ambiente, a Secretaria de Estado da Agricultura e Abastecimento e a União da Agroindústria Canavieira de São Paulo com a finalidade de adotar ações destinadas a consolidar o desenvolvimento sustentável da indústria da cana-de-açúcar no Estado de São Paulo, algumas delas descrita em sua Cláusula terceira - Diretivas Técnicas:

- Antecipar, nos terrenos com declividade até $12 \%$, o prazo final para eliminação da queimada da cana-de-açúcar, de 2021 para 2014, adiantando o percentual de cana não queimada em 2010, de 50\% para $70 \%$.

- Antecipar, nos terrenos com declividade acima de $12 \%$, o prazo final para eliminação da queimada da cana-de-açúcar, de 2031 para 2017, adiantando o percentual da cana não queimada, em 2010 de $10 \%$ para $30 \%$. 
- Não utilizar a prática de queima da cana-de-açúcar para fins de colheita nas áreas de expansão de canaviais.

Em sua Cláusula quarta - Apoio Governamental tem destaque:

- A administração pública estadual por sua vez atuará no sentido de fomentar a pesquisa para o aproveitamento energético e econômico do palhiço da cana-de-açúcar.

As Figuras 10 e 11 mostram os novos cronogramas de Eliminação de Queimadas no Estado de São Paulo.

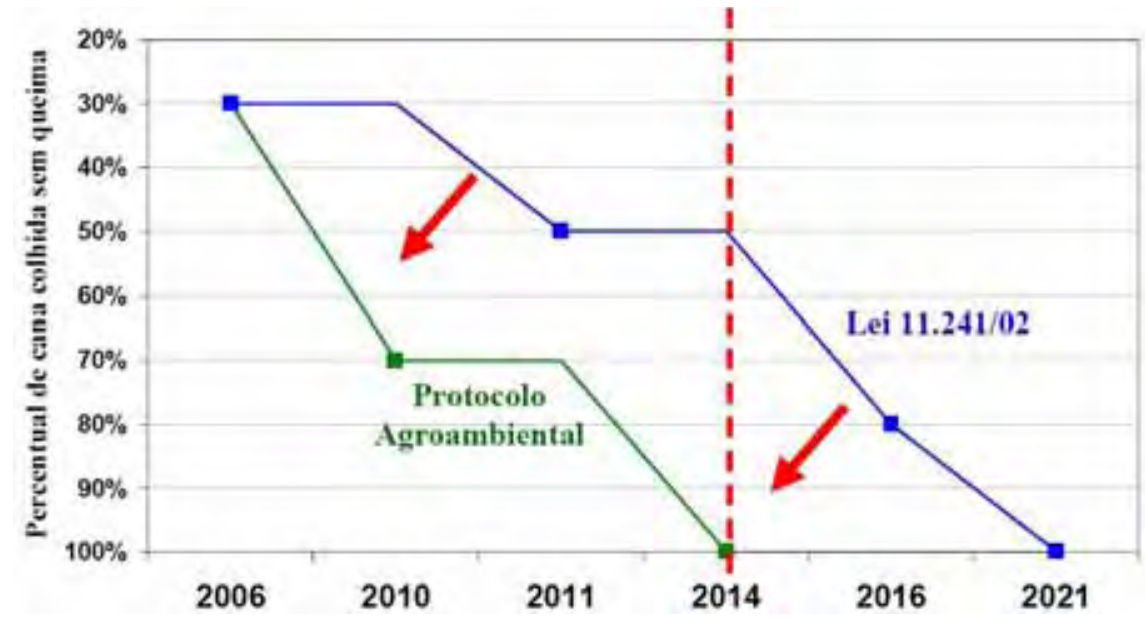

Figura 10 - Novo cronograma eliminação de queimadas terras mecanizáveis. Fonte: Secretaria do Meio Ambiente do Estado de São Paulo

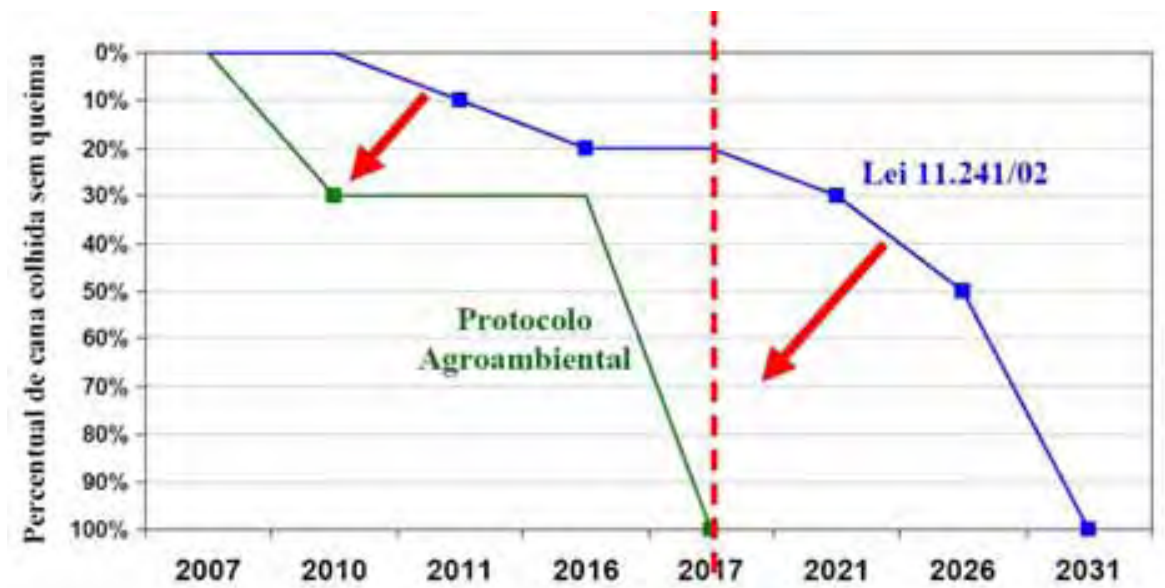

Figura 11 - Novo cronograma eliminação de queimadas terras não mecanizáveis. Fonte: Secretaria do Meio Ambiente do Estado de São Paulo 
Em março de 2008, também aderiu ao Protocolo Agroambiental a ORPLANA- Organização de Plantadores de Cana da Região Centro-Sul do Brasil, cujos fornecedores de cana representam $28 \%$ da produção total de cana-de-açúcar no Estado de São Paulo. Após dois anos do Protocolo Agroambiental em 2009 a Secretaria do Meio Ambiente mostrou sua evolução através dos dados comparativos das safras 06/07, 07/08 e 08/09 onde a colheita de cana crua evoluiu de $34,2 \%$ na safra $06 / 07$ para $49,1 \%$ na safra $08 / 09$, significando aumento de 810 mil hectares de cana colhido mecanicamente sem a utilização de fogo, conforme demonstrado na Figura 12.

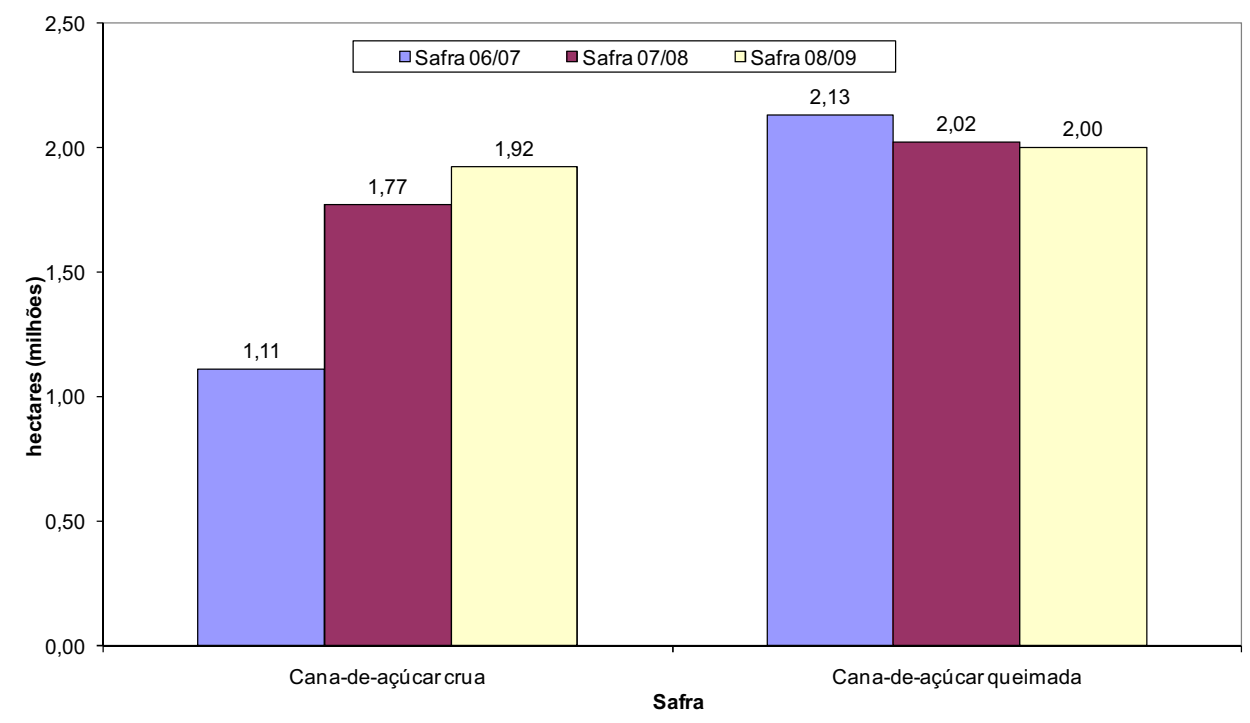

Figura 12 - Comparação entre as áreas de cana-de-açúcar colhidas com e sem queimada, safras 06/07 à 08/09.

Fonte: Secretaria do Meio Ambiente do Estado de São Paulo

Esses resultados conforme a SMA-Secretaria de Meio Ambiente (2009), apontam o fim da queima da cana-de-açúcar no Estado de São Paulo. A comparação entre a Lei Estadual 11.241/02 e os prazos estabelecidos pelo Protocolo agroambiental, que estão demonstrados na Figura 13, apresentam uma linha de tendência da colheita crua efetiva para a eliminação da utilização do fogo como prática de colheita da cana-de-açúcar para 2013, uma aceleração significativa, quando comparada com os prazos estabelecidos por lei. 


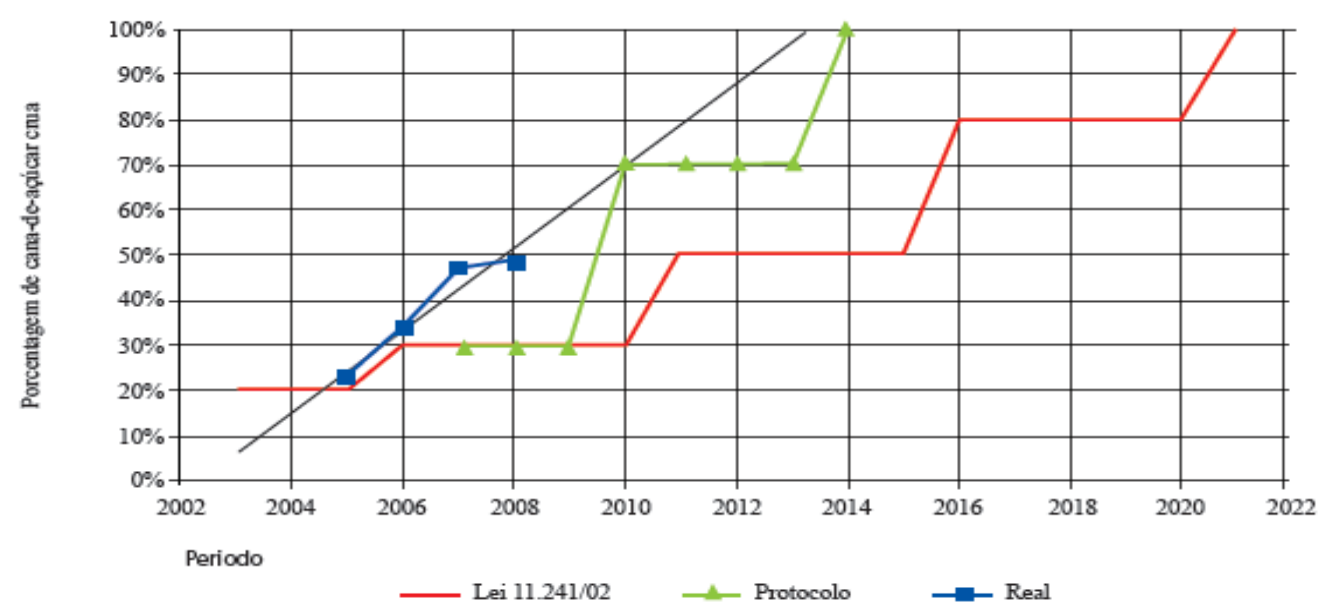

Figura 13 - Comparação entre a Lei 11.241/02, Protocolo agroambiental e dados reais de queima.

Fonte: SMA-Secretaria do Meio Ambiente do Estado de São Paulo

Ressalta ainda a SMA-Secretaria de Meio Ambiente que o avanço na colheita crua acima das porcentagens estabelecida de Lei 11.241/02 contribuiu para redução de emissão de poluentes atmosféricos e assim, no combate as mudanças climáticas.

Caso toda safra paulista seguisse a referida Lei, teríamos uma área de queima de 2.745.197 hectares, ou seja, 70\% da área plantada.

Isto significa que deixaram de ser queimados 767.564 hectares, havendo redução de cerca de 2,3 milhões de toneladas de monóxido de carbono, 200 mil toneladas de material particulado e 330 mil toneladas de hidrocarbonetos.

A Figura 14 resume os totais de cana-de-açúcar colhida nas últimas três safras e os avanços da colheita de cana-de-açúcar sem queimadas.

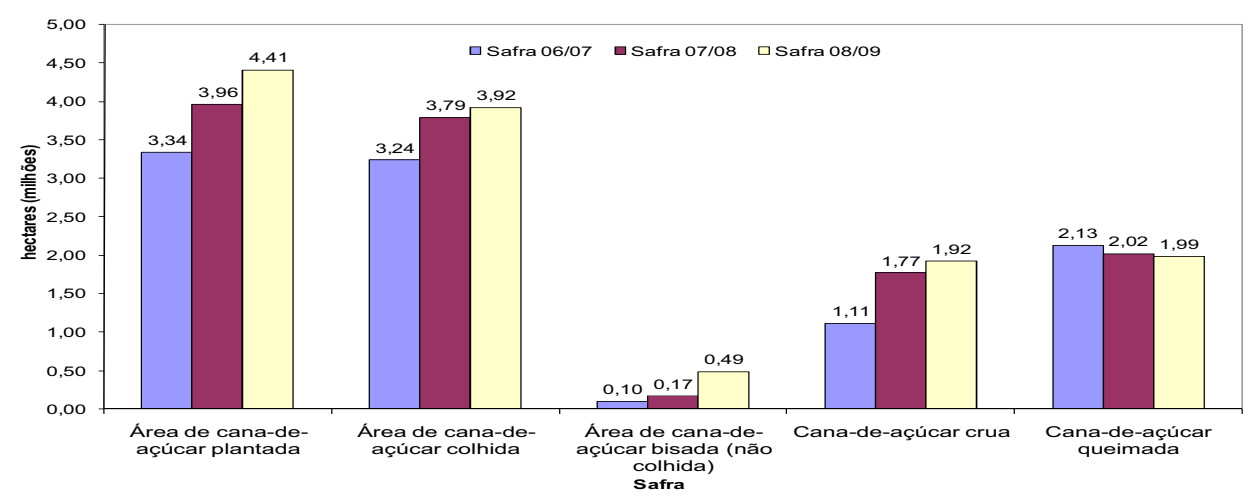

Figura 14 - Síntese dos dados das safras 06/07, 07/08 e 08/09.

Fonte: Secretaria do Meio Ambiente do Estado de São Paulo. 


\subsection{Efeitos da permanência do palhiço de cana-de-açúcar no campo}

Outra razão para recolhimento do palhiço é que, nas áreas onde a colheita da cana-de-açúcar é feita sem a queima, o palhiço não retirado favorece a infestação da praga "cigarrinha -da -raiz" (Mahanarva fimbriolata) que causa o ressecamento da cana-deaçúcar. O controle dessa praga é feito biologicamente, através da aplicação do fungo "Metarhizium anisopliae", que age por contato e tem que atingir as ninfas que se encontram protegidas pela palha.

Macedo et al. (2001), em estudo de monitoramento de populações e controle da cigarrinha-da-raiz da cana-de-açúcar, registrou a precipitação pluviométrica relacionado-a com os dados de levantamentos entre populações de ninfas e adultos, mostrou que a correlação entre precipitação pluviométrica e a presença da praga (considerando que o ciclo da praga em condições ideais) é de, aproximadamente, 60 dias. Pode-se estimar que a geração da praga inicia-se com as precipitações mais intensas, entre novembro/dezembro, e finda com o término do período chuvoso por volta de abril/maio. A captura crescente de adultos de Mahanarva fimbriolata no início da primavera e verão ou durante o período chuvoso (verão) evidencia o ataque da praga na área, tornando eminente a decisão quanto à necessidade ou não do controle.

A aplicação do fungo pode ser aérea com elevado rendimento, possibilidade de aplicação com solo molhado e cultura alta. A aplicação terrestre tem como vantagens a aplicação no alvo (touceiras), aplicação noturna, concentra a dose dos esporos em 3 vezes e quebra a barreira das folhas da cana-de-açúcar.

Arrigoni (2005) destacou que a praga atinge São Paulo e os Estados limítrofes e que dependendo dos níveis populacionais pode causar perdas significativas em média de 15 toneladas de cana-de-açúcar/ha-ano, além da redução de 1,5 pontos percentual no teor de açúcar e que, com o aumento da colheita mecanizada, houve significativo acréscimo de áreas infestadas por cigarrinhas. A Figura 15 mostra a evolução das populações da praga nas safras de 2001/2002 a de 2008/2009. 


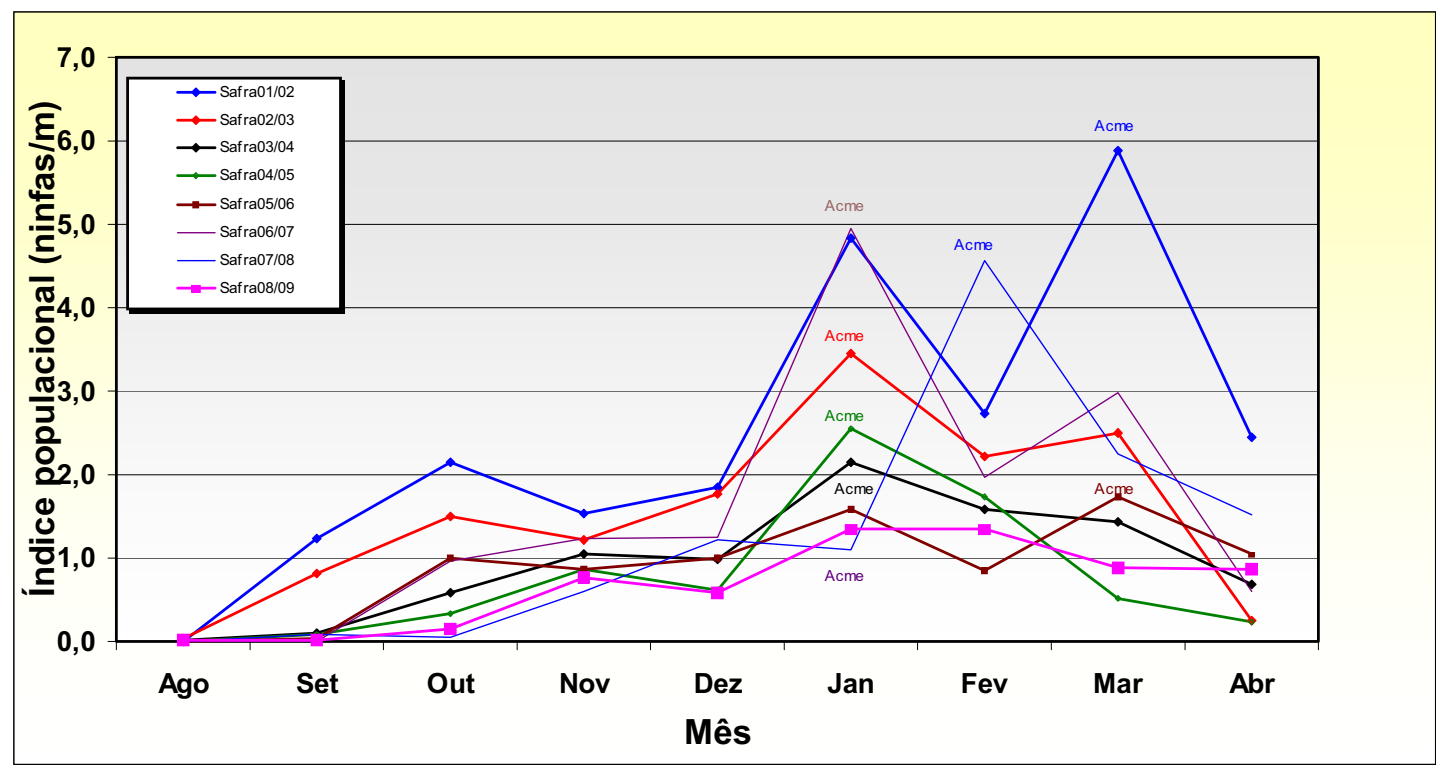

Figura 15 - Evolução das populações da cigarrinha-da-raiz. Fonte: CTC - Centro de Tecnologia Canavieira.

A presença da palha sobre o solo favorece a retenção de umidade nas regiões onde o clima no inverno é mais seco e a demanda por irrigação de salvamento ou complementar é grande. Em contrapartida, nas regiões onde o inverno é mais úmido ou frio, a retirada da palha de cima da soqueira será fundamental para garantir a boa brotação na maioria das variedades.

Rípoli (2007) lembra que o termo correto é palhiço, pois a palha é um dos seus constituintes, o palhiço evita o impacto de gotas de chuva sobre o terreno, controlando a erosão do solo. $50 \%$ do palhiço devem permanecer no campo, pois devido ao abafamento, ele controla a maioria das ervas daninhas, levando a uma economia significativa de herbicidas e estimulando a aplicação localizada dos mesmos; mantém mais uniforme a umidade do solo nos primeiros $5-10 \mathrm{~cm}$ do perfil e mantém em limites menos extremos a variação da temperatura desse perfil, sendo que ambos os fatores favorecem a agricultura, o palhiço tornase alimento para a biota (fauna do solo) transformando-se em húmus, o que por sua vez irá melhorar a relação $\mathrm{C} / \mathrm{N}$ do solo e facilitar um melhor aproveitamento dos fertilizantes aplicados. A Figura 16 apresenta o efeito herbicida do palhiço. 


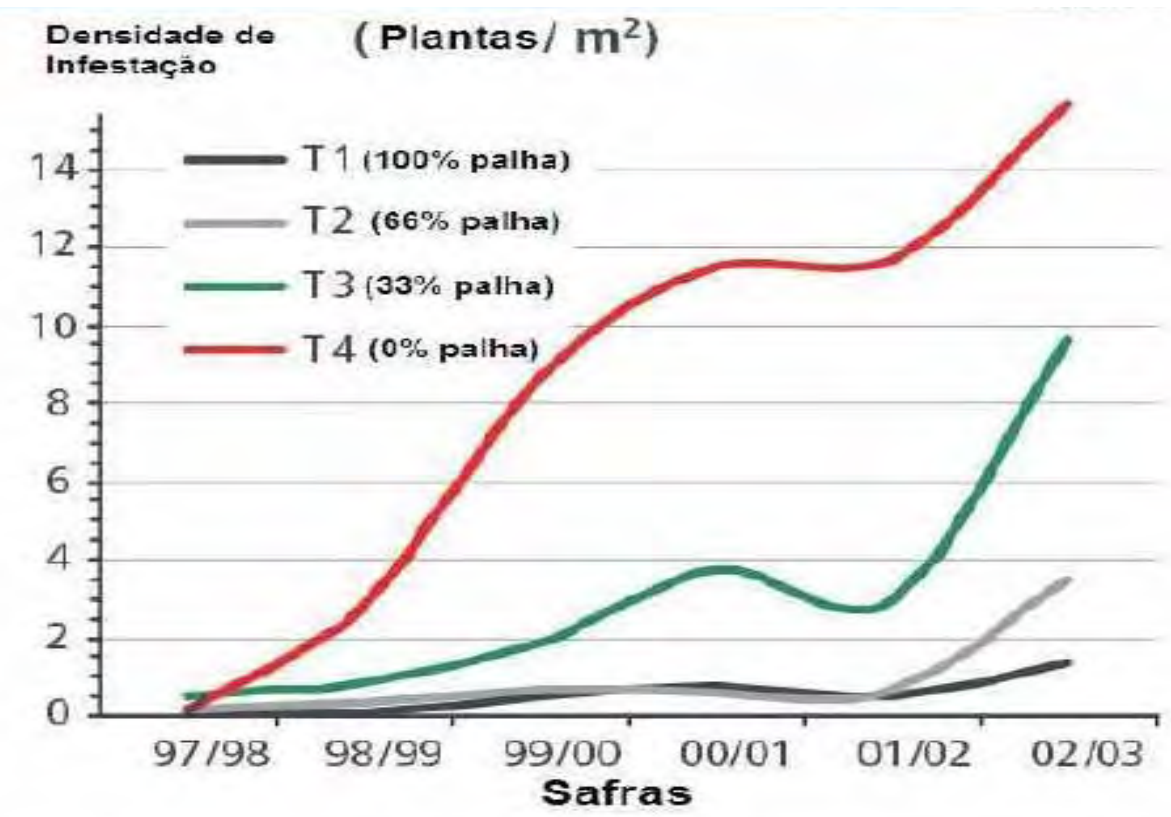

Figura 16 - Efeito herbicida do palhiço

Fonte: CTC - Centro de Tecnologia Canavieira (2005) 


\section{MATERIAL E MÉTODOS}

O presente trabalho de pesquisa foi realizado em três indústrias sucroalcooleiras, localizadas no Estado de São Paulo, que estão operando com aproveitamento de palhiço como combustível complementar para suas caldeiras, em queima conjunta com o bagaço residual da moagem da cana-de-açúcar.

\subsection{Métodos de recolhimento de palhiço de cana-de-açúcar no campo.}

\subsubsection{Recolhimento com colhedora para forrageiras, na Usina A.}

Localizada na região central do Estado de São Paulo essa Usina, durante a safra 2008/2009, processou 7.378.408 t de cana-de-açúcar. Possuía três linhas de moendas e $47 \%$ da cana-de-açúcar recebida era proveniente da colheita mecanizada.

Devido à escassez de bagaço para sua atividade de refinação de açúcar, que ocorre nos 12 meses do ano, independentemente do período de safra, esta Usina implantou um projeto de recolhimento de palhiço, após a colheita da cana-de-açúcar, utilizando máquinas agrícolas para forrageiras de fabricação CLASS, tipo Jaguar $860^{1}$, com motor de $435 \mathrm{cv}$ e largura de alimentador de 3,00 metros. Estas máquinas faziam a safra de sorgo no Uruguai, e foram contratadas sob o regime de prestação de serviço, já que era época de entressafra de colheita naquele país e, após manutenção ficavam ociosas.

\footnotetext{
${ }^{1}$ A citação de marcas ou modelos, não se entende como recomendação do autor.
} 
O recolhimento do palhiço se dava após a operação de aleiramento do mesmo que era feito pelo implemento New Holland modelo Rolabar 256 com largura de 3,00 metros acoplada a tomada de força de trator Ford 5360. O palhiço recolhido era transportado em caminhões do tipo semi-reboque até a indústria onde a carga era pesada em balança rodoviária, tinha sua procedência identificada em planilha de controle e uma amostra retirada para determinação da umidade e da impureza mineral.

Durante o período de recolhimento do palhiço, foram apropriados os gastos com aluguel das máquinas, combustíveis, lubrificantes e transporte para apropriação do custo final da tonelada de palhiço posta na Usina.

O experimento transcorreu em um período de tempo de 195 dias, durante todo o seu período de safra, com área de recolhimento de 3.583,61 hectares, distribuídos em 34 fazendas de cana-de-açúcar.

Foram avaliados:

\subsubsection{Produtividade do recolhimento}

Determinadas em tonelada/hectare, através de peso em balança e área de colheita dimensionada.

\subsubsection{Desempenho da máquina por característica de solo}

Apurados em toneladas por hectare, em solo arenoso e solo argiloso.

\subsubsection{Consumo de combustível da máquina $(1 / \mathrm{t})$}

Apurado através de controle da reposição de combustível, feito através de medidor de vazão de engrenagens ovais e dos pesos das cargas efetuadas através do peso em balança.

\subsubsection{Umidade do palhiço}

Para essa determinação, primeiramente tara-se o cesto de secagem, em seguida pesa-se, em balança de precisão $(0,1 \mathrm{~g})$, a amostra de palhiço no cesto de secagem, anotando-se o peso úmido do bagaço (Pup), tomando-se o cuidado de distribuir o palhiço por igual no cesto. Seca-se em estufa à temperatura de $105^{\circ} \mathrm{C}$, até peso constante (aproximadamente 30 minutos). Retira-se e pesa-se, anotado o peso, retorna-se a estufa, 
deixando por mais 5 minutos. Pesa-se novamente, e se a perda de peso não for superior a 0,1 grama aceita-se a segunda pesagem. Se a diferença for maior, seca-se por mais 5 minutos. Anota-se o peso (Psp). A umidade do palhiço fica determinada pela Eq. 1, expressa em \%.

$$
U p=\frac{(P u p-P s p)}{P u p} .100
$$

Onde:

$U P=$ umidade do palhiço, $\%$;

Pup = peso úmido do palhiço, g;

$P s p=$ peso seco do palhiço, g.

\subsubsection{Impureza Mineral}

Para esta determinação deve-se tarar o cesto de incineração (Tci), colocar aproximadamente $100 \pm 0,5 \mathrm{~g}$ da amostra no cesto (Pap), pesada em balança de precisão de 2 casas decimais e distribuir de forma homogênea a amostra no cesto. Coloca-se o cesto na mufla de incineração, começando a contar o tempo quando esta atingir a temperatura de $650^{\circ} \mathrm{C}$, deixando-o durante 2 horas à temperatura de $700^{\circ} \mathrm{C} \pm 15^{\circ} \mathrm{C}$. Pesa-se o resíduo (Psp) após a amostra estar completamente fria. A impureza mineral fica determinada pela Eq. 2, expressa em \%.

$$
\operatorname{Imp}=\frac{(p s p-T c i)}{P a p} .100
$$

Onde:

Imp = impureza mineral do palhiço, $\%$;

$P s p=$ peso seco do palhiço, $\mathrm{g}$.

$T c i=$ tara do cesto de incineração, $\mathrm{g}$;

Pap $=$ peso amostra de palhiço, $\mathrm{g}$;

\subsubsection{Carga média transportada}

Apurada através de peso em balança pela Eq. 3:

$$
C m t=\frac{P r t}{N v}
$$


Onde:

$C m t=$ carga média transportada, $\mathrm{t}$;

Prt $=$ palhiço recolhido total, $\mathrm{t}$;

$N v=$ número de viagens.

\subsubsection{Número de viagens}

Registro em planilha do número de viagens efetuadas para entregar o palhiço recolhido na usina.

\subsubsection{Distância média percorrida}

Determinada pela distancia total percorrida para entregar o palhiço recolhido na usina, dividida pelo número de viagens efetuadas, conforme Eq. 4

$$
D m p=\frac{\sum D p}{N v}
$$

Onde:

$D m p=$ distancia média percorrida, $\mathrm{km}$;

$D p=$ distancia percorrida por viagem, $\mathrm{km}$;

$N v=$ número de viagens.

\subsubsection{Custo da viagem do palhiço recolhido posto na usina}

Determinado pela somatória dos custos totais envolvidos no recolhimento e transporte, dividido pelo número de viagens efetuadas, conforme Eq. 5.

$$
C v=\frac{\sum C t}{N v}
$$

Onde:

$C v=$ custo por viagem, $\mathrm{R} \$$ e USD;

$C t=$ custos totais, $\mathrm{R} \$$

$N v=$ número de viagens 


\subsubsection{Custo da tonelada do palhiço recolhido, posto na usina}

Apurado pela somatória dos custos totais $(\mathrm{Ct})$ envolvidos no recolhimento e transporte, dividido pela quantidade recolhida e entregue na usina (Qpu) conforme Eq. 6.

$$
C t p u=\frac{\sum C t}{O p u}
$$

Onde:

$C t p u=$ custo tonelada de palhiço posto na usina, R\$ e USD;

$C t=$ custos totais, $\mathrm{R} \$$

$Q p u=$ Quantidade de palhiço posto na usina, t.

A Figura 17 apresenta a máquina Jaguar 860 em operação e a Figura 18 apresenta o caminhão com palhiço descarregando no pátio de bagaço da indústria.

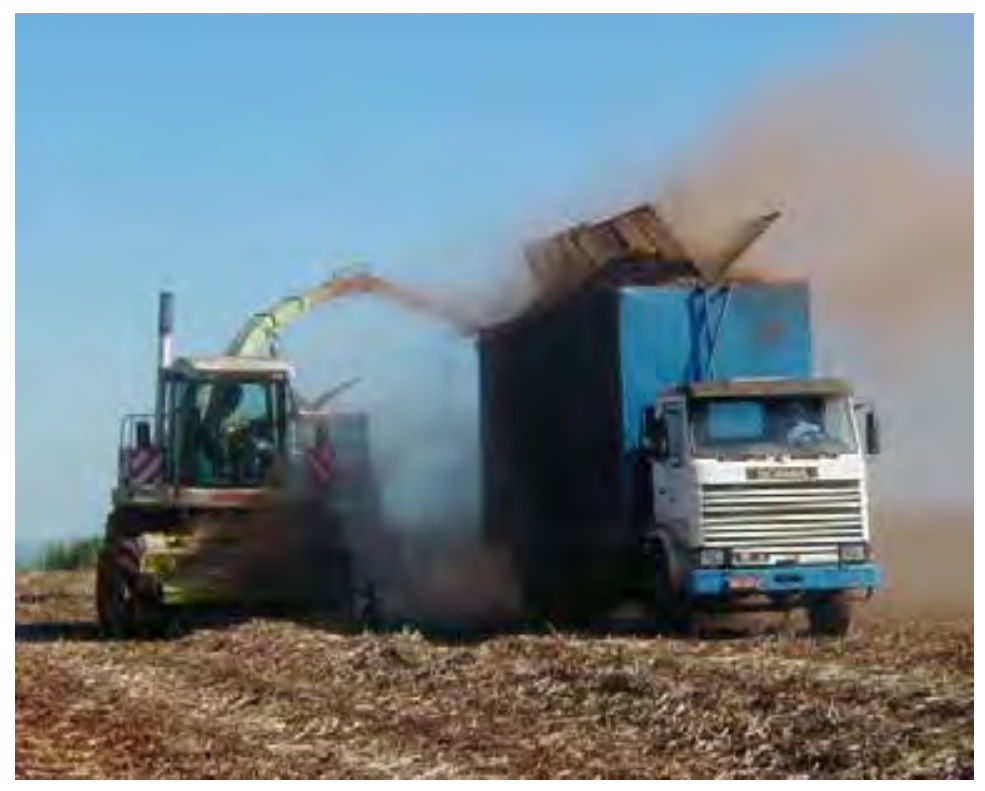

Figura 17- Colhedora Class Jaguar 860 recolhendo palhiço enleirado. 


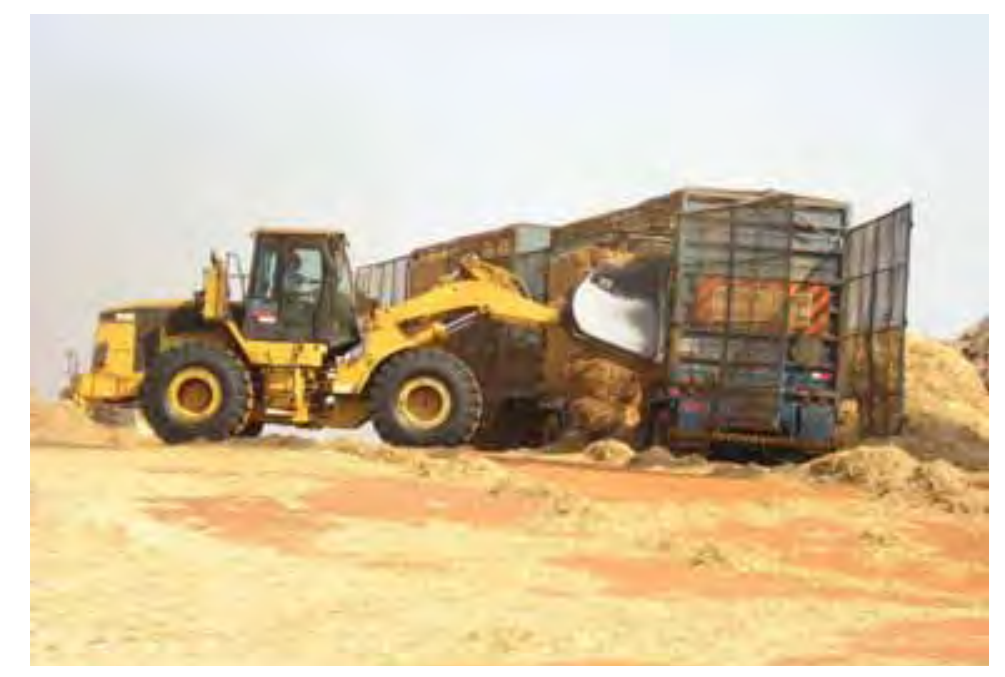

Figura 18 - Caminhão com palhiço sendo descarregado no pátio de bagaço.

\subsubsection{Recolhimento de palhiço com colhedora "Twyster," na Usina A.}

Em 2007, o setor agrícola da Usina A, em parceria com um fabricante nacional de máquina forrageira, desenvolveu equipamento específico que recolhia parcialmente o palhiço após a colheita da cana-de-açúcar, sem a operação de aleiramento, deixando uma quantidade de palhiço remanescente no campo, adequada para o novo brotamento da cana-de-açúcar ("soca”). Esse equipamento é apresentado na Figura 19.

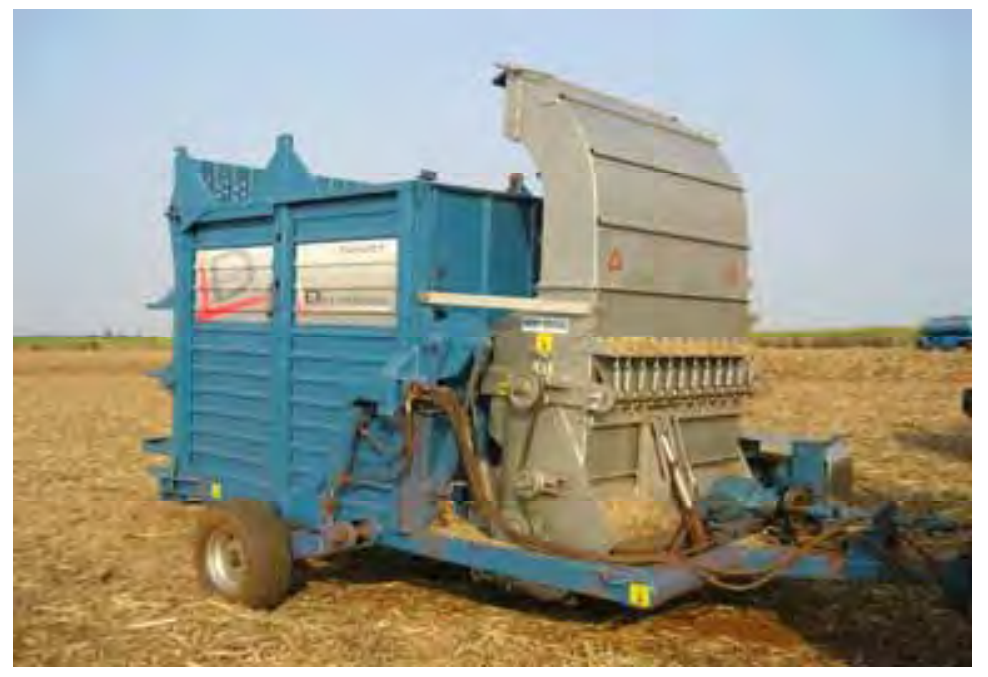

Figura 19 - Colhedora Twyster da Deltamaq.

O equipamento denominado Twyster Press 5000 necessitava de um trator Massey Ferguson MF 6350, de potência 180 CV e continha um dispositivo hidráulico, acionado pela tomada de potência do trator, a $2200 \mathrm{rpm}$ em primeira marcha, o qual transferia 
o palhiço recolhido para um outro equipamento de transbordo de capacidade $10,5 \mathrm{~m}^{3}$ de volume, com dispositivo de elevação, que possibilitava a descarga em caminhões do tipo basculante para ser transportado para a indústria. O transbordo também foi desenvolvido pela Deltamaq, denominado Twyster Box e era tracionado por trator marca Valtra modelo VT 110.

O equipamento Twyster Press 5000, constituído de dois rotores recolhedores/picadores, sendo que o rotor inferior operava a $2387 \mathrm{rpm}$ e o rotor superior a $2615 \mathrm{rpm}$. A velocidade de deslocamento do equipamento era de 4,3 km/h. Foram escolhidas e demarcadas áreas em 2 fazendas onde já se havia sido feita a colheita da cana-de-açúcar, num total de 4,15 hectares. Os experimentos foram com recolhimento do palhiço seco, em média 4 dias após a colheita da cana-de-açúcar, e com palhiço verde, praticamente junto com a colheita da cana-de-açúcar. Os experimentos ocorreram no período de 29 de agosto a 01 de setembro de 2007.

O palhiço recolhido foi transportado até a Usina A, onde teve o peso registrado na balança rodoviária para verificação da massa específica. Foi coletada uma amostra para análise de impureza mineral e umidade. Os dados obtidos foram registrados em planilha para tabulação dos resultados.

\subsubsection{Produtividade do recolhimento}

Determinadas em tonelada/hectare, através de peso em balança e área de colheita dimensionada.

\subsubsection{Desempenho da máquina por característica de palhiço.}

Apurados em toneladas por hectare, com palhiço seco e palhiço verde.

\subsubsection{Umidade do palhiço}

Determinado conforme Eq. 1, item 5.1.1.4.

\subsubsection{Impureza Mineral}

Determinado conforme Eq. 2, item 5.1.1.5. 


\subsubsection{Massa específica do material}

Apurada através de peso em balança pela Eq. 7:

$$
M e=\frac{P r}{V b}
$$

Onde:

$$
\begin{aligned}
& M e=\text { massa especifica }, \mathrm{kg} / \mathrm{m}^{3} ; \\
& P r=\text { palhiço recolhido, } \mathrm{kg} ; \\
& V b=\text { volume do Box }, \mathrm{m}^{3}
\end{aligned}
$$

\subsubsection{Distância média percorrida}

Determinada pela distancia média estimada pela usina.

\subsubsection{Custo da viagem do palhiço recolhido posto na usina}

Determinado pela Tabela de Custos Operacionais praticados pela usina.

\subsubsection{Custo da tonelada do palhiço recolhido, posto na usina}

Apurado pela somatória dos custos totais $(\mathrm{Ct})$ envolvidos no recolhimento e transporte, obtidos da Tabela de Custos Operacionais da usina.

\subsubsection{Desempenho operacional dos equipamentos}

Apurado através das medições dos tempos gastos nas operações.

Esses equipamentos são apresentados nas Figuras 20, 21 e 22. 


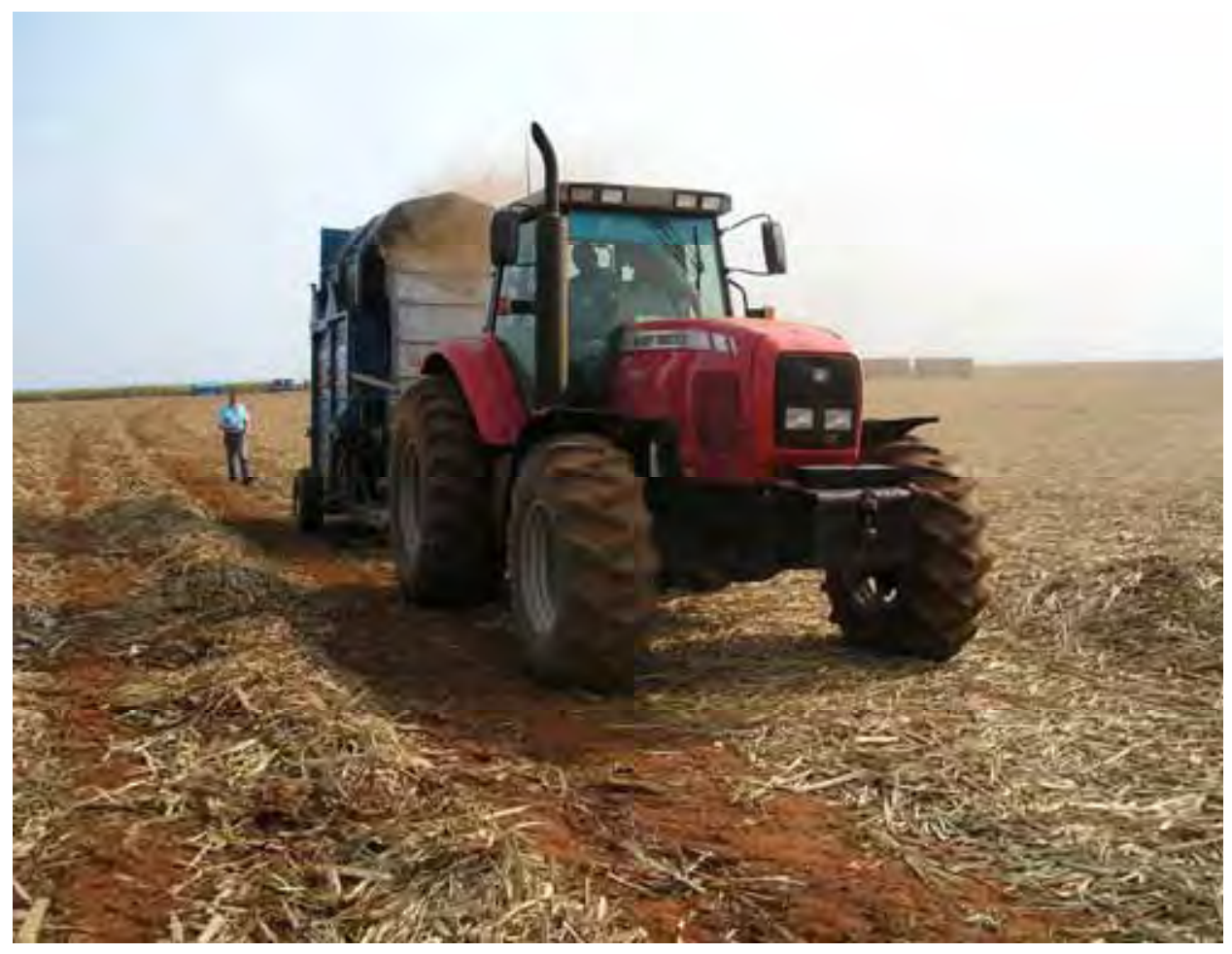

Figura 20 - Colhedora Twyster Press 5000 em operação recolhendo palhiço sem enleiramento.

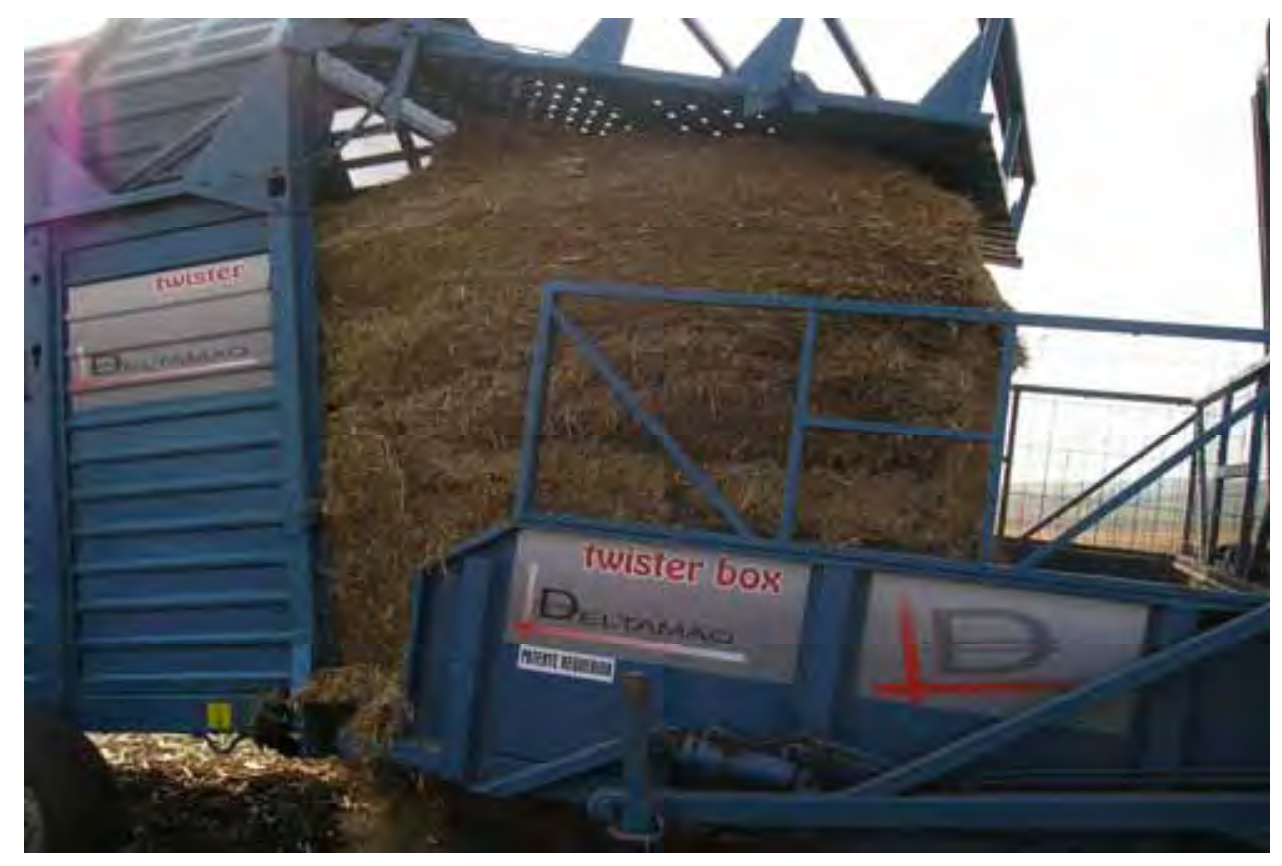

Figura 21 - Transferência de palhiço da colhedora para a carreta Twyster Box. 


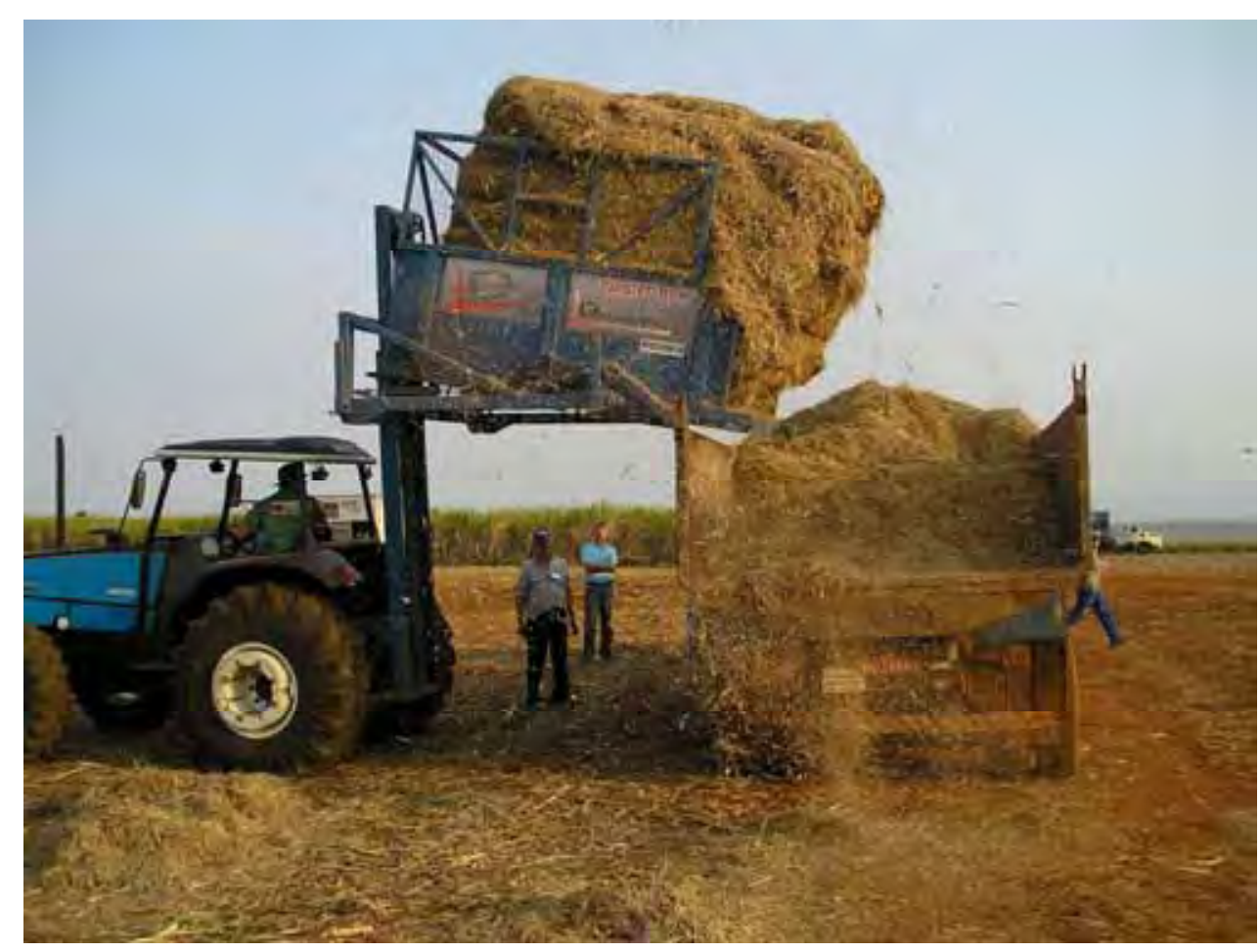

Figura 22 - Carregamento de caminhão basculante realizado pela carreta Twyster Box.

\subsubsection{Recolhimento de palhiço com máquina colhedora e enfardadora, na Usina B.}

Localizada na região central do Estado de São Paulo, esta Usina atingiu na safra 2008/2009 a marca de 4.222.913 t de cana-de-açúcar moída, com duas linhas de moendas que recebem $28 \%$ de colheita mecanizada.

Essa usina terceirizou para uma empresa de prestação de serviço agrícola o recolhimento de palhiço que foi feito após a colheita da cana-de-açúcar, com enfardadora do tipo câmara fixa, modelo Agroforn AF 120, com largura do recolhedor (pickup) de $1600 \mathrm{~mm}$, potência exigida $70 \mathrm{CV}$ e propelida com trator Massey Ferguson MF 275, formando fardos cilíndricos de dimensões $1200 \mathrm{~mm}$ x $1200 \mathrm{~mm}$, com produção nominal de 30 fardos/hora.

A máquina tinha o seguinte principio de funcionamento: $\mathrm{O}$ "pick-up" recolhe o palhiço conduzindo-o diretamente na câmara. A rotação contínua de rolos e corrente comprimem o palhiço com movimento rotatório. O palhiço é prensado de maneira crescente, comprimindo o fardo mais na parte externa do que no núcleo. Ao completar o enchimento da câmara, está formado um fardo com uma camada externa particularmente prensada e muito 
resistente às variações climáticas. Feita a amarração a tampa traseira se abre hidraulicamente e o fardo é empurrado para fora.

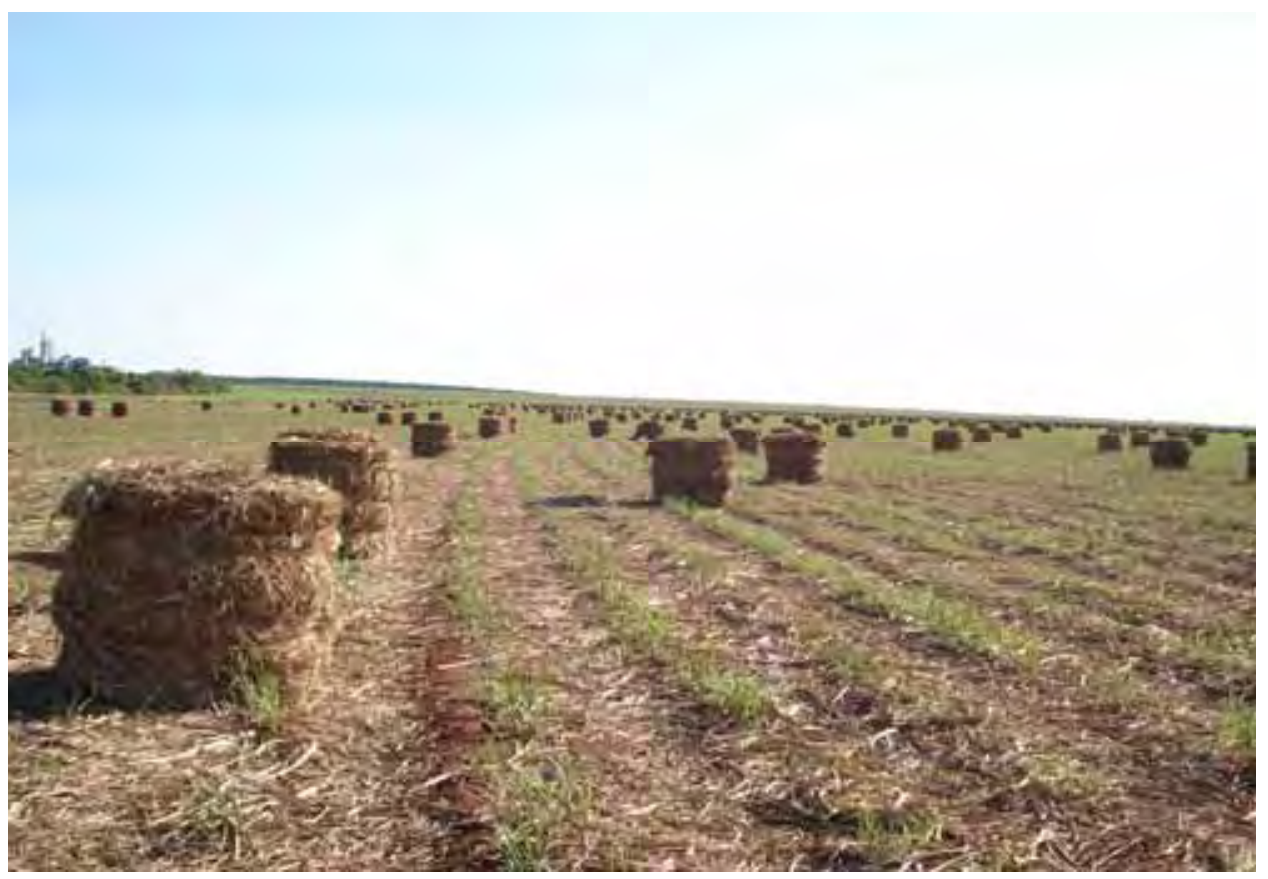

Figura 23 - Fardos cilíndricos no campo, aguardando transporte.

A Figura 23 apresenta fardos cilíndricos de palhiço ainda no campo, aguardando transporte para a indústria que é realizado por caminhões de carroceria, ou caminhões de transporte de cana-de-açúcar, tipo carroceria de fueiros, carregados por máquinas carregadoras de fabricação Santal, instaladas em trator Massey Fergu son MF 290.

Foram avaliados:

\subsubsection{Produtividade do recolhimento}

Determinadas em tonelada/hectare, através de peso em balança e área de colheita dimensionada.

\subsubsection{Umidade do palhiço}

Determinado conforme Eq. 1, item 5.1.1.4.

\subsubsection{Impureza Mineral}

Determinado conforme Eq. 2, item 5.1.1.5. 


\subsubsection{Custo da viagem do palhiço recolhido posto na usina}

Apurado pelo custo do transporte do palhiço em $t$, multiplicado pela massa média transportada por viagem.

\subsubsection{Custo da tonelada do palhiço recolhido, posto na usina}

Determinado conforme Eq. 6, item 5.1.1.10.

\subsubsection{Análise qualitativa do desempenho da máquina.}

Observações realizadas durante as operações de recolhimento e enfardamento do palhiço.

$\mathrm{Na}$ forma como apresentado, o palhiço não conseguia ser utilizado como combustível nas caldeiras da usina, necessitando ser picado para ser misturado ao bagaço da cana-de-açúcar, que é o combustível principal da usina.

Essa modalidade de recolhimento de palhiço, então, tem que ser complementada com um sistema de preparação ou picagem do palhiço para que consiga a finalidade que é o seu uso como energético na área industrial da usina.

A usina tinha instalado na indústria um sistema de trituração de palhiço de fabricação Tectrix, capacidade nominal 140 toneladas/hora e capacidade efetiva 80 toneladas/hora, que tem como princípio desfibrar o palhiço, passando-o entre um rotor giratório e uma placa fixa, acionamento com 2 motores elétricos de potência $250 \mathrm{cv}$. Como não apresentava bom desempenho, recorreu-se ao expediente de, em dias de chuva, quando havia redução de moagem, ou no final da safra, destinar uma de suas moendas para triturar o palhiço, remanescente em seu estoque ainda em fardos cilíndricos. Esses fardos têm a corda sizal que os amarra cortada e são carregados em caminhões próprios para o transporte de canade-açúcar, e transportados e tombados na mesa alimentadora da moenda, passando pelo processo de preparo e moagem como se fosse cana-de-açúcar. A moenda usa o seu sistema de embebição de moagem em circuito fechado de modo a minimizar a poeira que se forma. Esse processo é apresentado pela Figura 24 (carregamento dos caminhões), Figura 25 (palhiço sendo tombado na mesa alimentadora da moenda), Figura 26 (palhiço encaminhado para a moenda pelas esteiras transportadoras) e Figura 27 (palhiço passando por um dos ternos da moenda como se fosse cana-de-açúcar). 


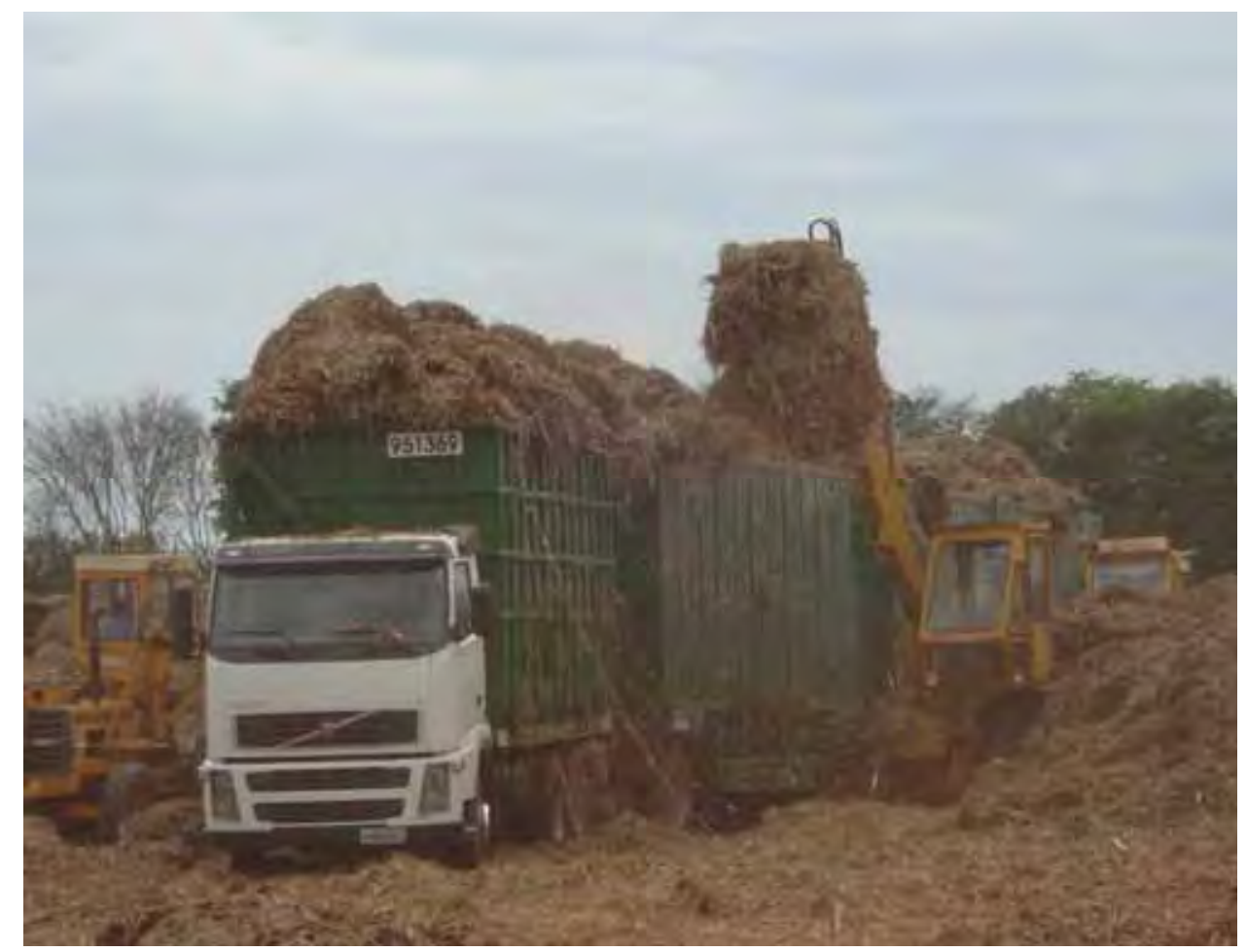

Figura 24 - Carregamento de palhiço em caminhões de transporte de cana-de-açúcar.

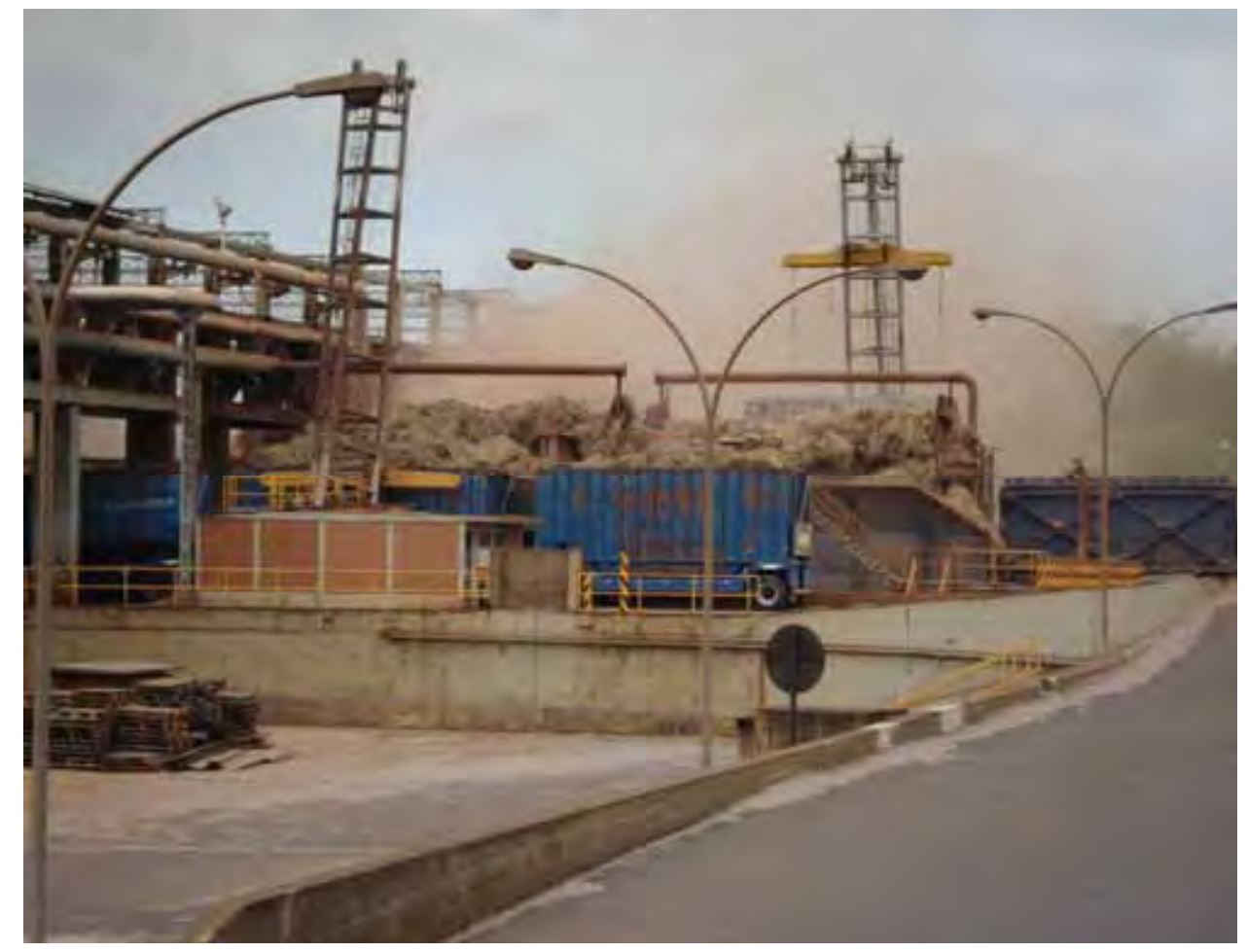

Figura 25 - Palhiço sendo tombado nas mesas alimentadoras da moenda. 


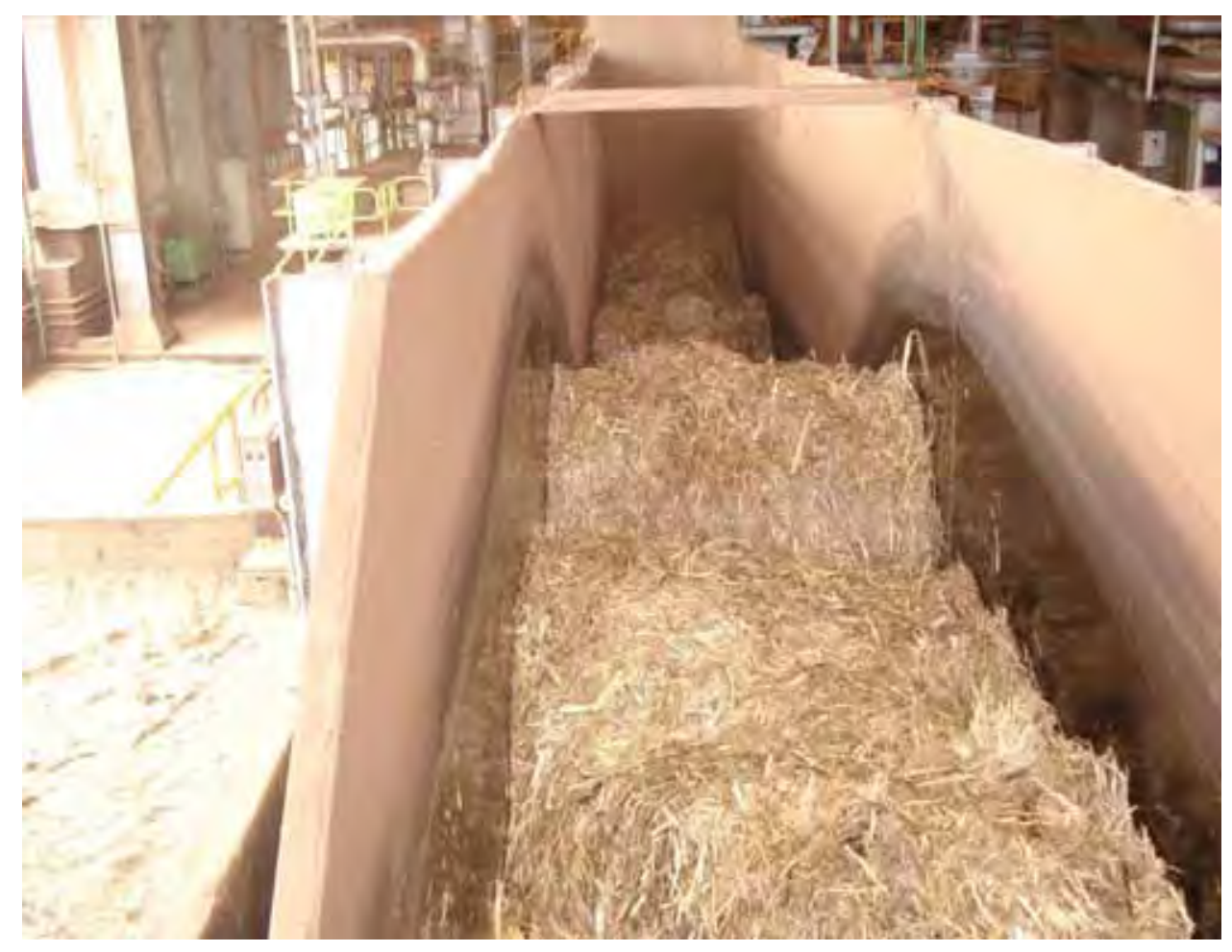

Figura 26 - Palhiço sendo conduzido à moenda pelas esteiras transportadoras.

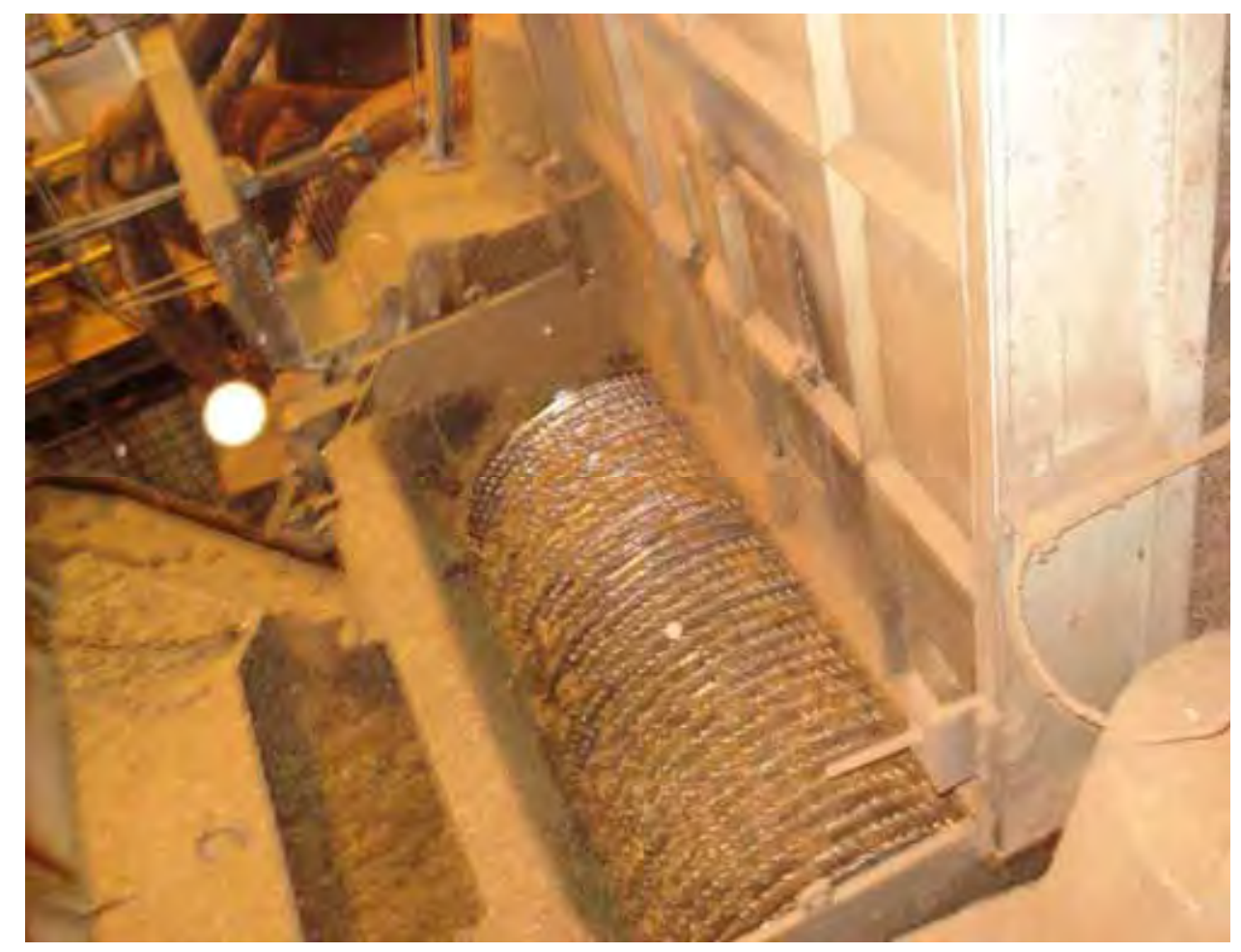

Figura 27 - Palhiço sendo moído em um dos ternos da moenda de cana-de-açúcar. 


\subsection{Otimização de sistema de separação do palhiço na indústria.}

A alternativa de se levar o palhiço junto com a cana-de-açúcar está sendo o método mais utilizado pelas usinas, por apresentar maior flexibilidade operacional, considerando a colheita parcialmente integral. Também, apresenta vantagem em relação ao recolhimento no campo pelo menor índice de impureza mineral, pois o palhiço não é recolhido do solo e a impureza trazida ainda diminui após a separação do palhiço pelo sistema de limpeza a seco.

Localizada na região centro-sudeste do Estado de São Paulo, a Usina C processou 2.560.949 t de cana-de-açúcar na safra 2008/2009 em uma linha de moenda com capacidade diária de 11.000 t. A colheita mecanizada representou $38 \%$ da cana-de-açúcar moída.

Na lavoura mecanizada, essa usina utilizava colhedoras de fabricação Case modelo 7700, sobre esteiras, com motor de $335 \mathrm{cv}$ de potência, sistema de transmissão hidrostática, bitola $1880 \mathrm{~mm}$, com extrator primário de acionamento hidráulico e com 1280 mm de diâmetro do ventilador e extrator secundário com ventilador de diâmetro $940 \mathrm{~mm}$, também com acionamento hidráulico, que possibilita a variação de velocidade, condição essa, essencial para o experimento realizado.

A colhedora corta a cana-de-açúcar em toletes de tamanho médio 200 $\mathrm{mm}$ e, por meio de um elevador, a deposita em uma carreta denominada transbordo com capacidade para 8 toneladas, tracionadas por um trator de $160 \mathrm{cv}$. O transbordo é dotado de um sistema hidráulico de elevação e articulação, que faz com que a carga seja descarregada nos caminhões que a transportam até a indústria.

Os toletes ou colmos da cana-de-açúcar são carregados juntamente com a quantidade de palhiço que se deseja, usando-se a variação de velocidade da hélice do extrator secundário, sendo que, quanto maior a velocidade de operação, menos palhiço é carregado.

O sistema de recepção da cana-de-açúcar com palhiço colhida mecanicamente e a separação do palhiço recebido era composto de um guindaste tipo Hillo (sistema de guindaste fixo no chão e que, através de cabos e roldanas, eleva a caçamba ou a 
carga do veículo com cana-de-açúcar descarregando-a em mesa alimentadora ou moega), com capacidade de elevação e articulação de carrocerias de 42 t, uma moega de recepção com capacidade para 40 t. Na sequência, existia uma esteira transportadora com 18 metros de comprimento, do tipo taliscas metálicas, de largura $2130 \mathrm{~mm}$, acionada por motor elétrico de potência $75 \mathrm{cv}$, conectado a um inversor de freqüência que possibilita variar a velocidade da esteira de 0 a 9 metros por minuto. $\mathrm{Na}$ saída da esteira metálica, existe um equipamento alimentador rotativo denominado nivelador (Figura 28), acionado por motor elétrico de potência $30 \mathrm{cv}$ e $1750 \mathrm{rpm}$. Esse dispositivo realiza a dosagem da cana na próxima esteira instalada em sequência, de maneira que esta fique com uma camada não muito espessa, para facilitar a sopragem do palhiço, quando da passagem pelo bico soprador.

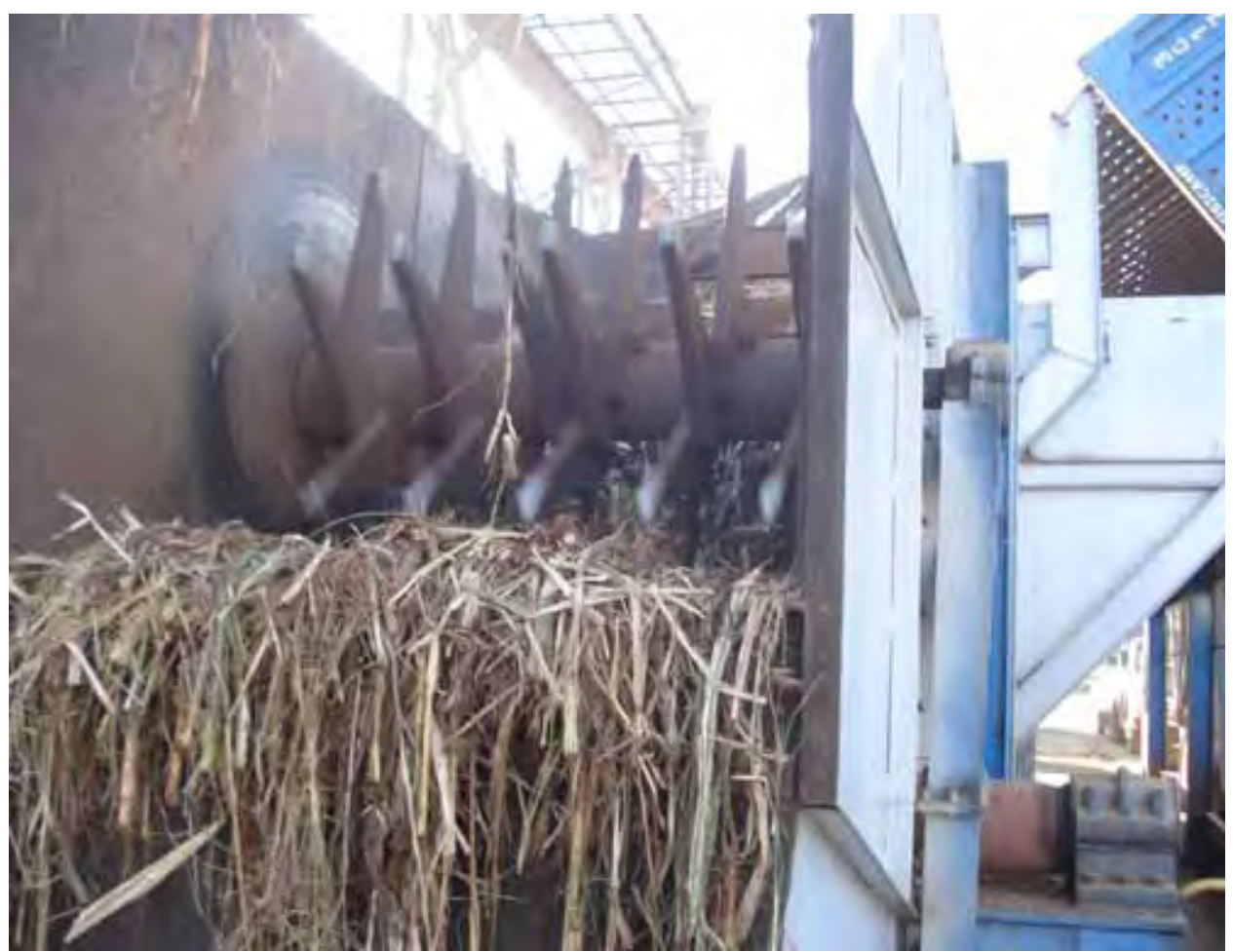

Figura 28 - Nivelador instalado na esteira de cana-de-açúcar.

Na sequência, após a esteira metálica, existe uma esteira de lona com comprimento de 41 metros e largura $2330 \mathrm{~mm}$, acionada por motor elétrico de $60 \mathrm{cv}$ e 1750 rpm, que conduz a cana-de-açúcar, ainda com palhiço, até o sistema de sopragem.

O sistema de sopragem é composto de um ventilador centrífugo com vazão de $70000 \mathrm{~m}^{3} / \mathrm{h}$ à pressão de $250 \mathrm{mmca}$, acionado por motor elétrico de potência $100 \mathrm{cv}$ e $1750 \mathrm{rpm}$. O jato de ar sai pelo bico soprador sobre a cana-de-açúcar, fazendo com que o 
palhiço e as impurezas, que são mais leves, caiam na câmara de separação e os colmos da cana-de-açúcar, mais pesados, na esteira que alimenta a moenda.

O palhiço soprado para a câmara de despressurização é conduzido por uma esteira de lona instalada na parte inferior dessa câmara, até uma esteira de arraste denominada cuch-cush onde, no caso dessa usina, é lavado para retirada das impurezas minerais. A seguir, através de uma esteira transportadora de lona, o palhiço é enviado ao ultimo terno da moenda para ser triturado com a cana-de-açúcar. A Figura 29 mostra o sistema de sopragem.

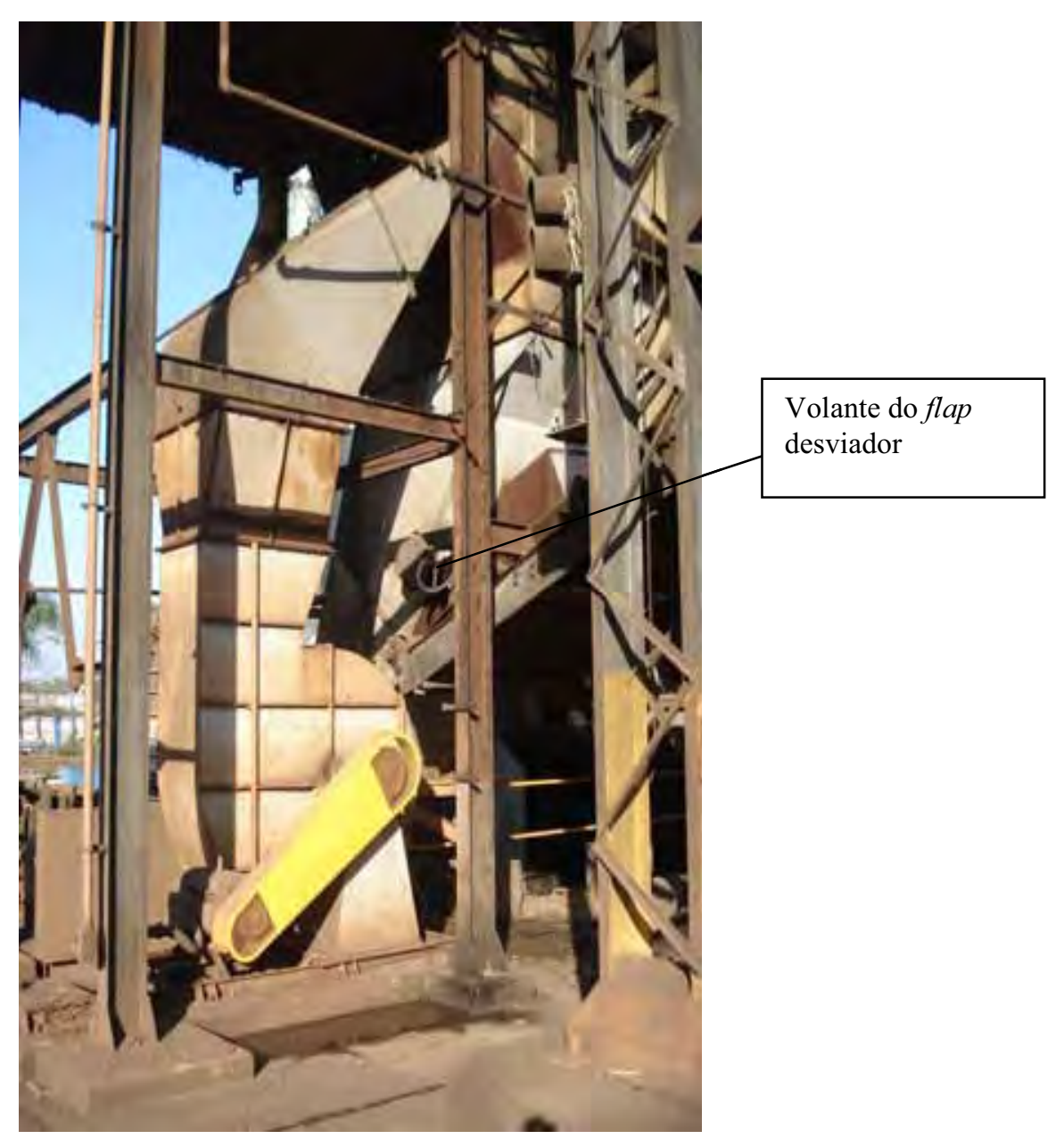

Figura 29 - Conjunto ventilador e bico soprador. 
Para determinação da eficiência do sistema de separação do palhiço recebido com a cana-de-açúcar, foi estabelecido que fossem amostradas cargas de cana-deaçúcar, colhidas com a rotação do extrator de palhiço da colhedora, variando sua velocidade entre 650 e $900 \mathrm{rpm}$, desejando-se avaliar as diferenças de desempenho ao se trabalhar com cargas com teor de palhiço entre 13 e 7\%, respectivamente. A eficiência do sistema de separação foi determinada pela eq. 8:

\subsubsection{Determinação da eficiência do sistema de separação}

Determinada pela da Eq. 8

$$
E s=\frac{(Q p a s-Q p d)}{Q p a s} .100
$$

Onde:

$E s=$ eficiência de sopragem, \%;

Qpas = quantidade de palhiço antes da sopragem, $\mathrm{kg}$;

Qpds = quantidade de palhiço depois da sopragem, $\mathrm{kg}$

Em observações anteriormente realizadas, verificou-se que, ainda após a cana-de-açúcar ter passado pelo processo de limpeza a seco, havia palhiço misturado aos colmos. Para se determinar o quanto de palhiço ficava remanescente, estabeleceu-se que a carga de cana-de-açúcar deveria passar por uma segunda etapa de limpeza. Adaptou-se uma esteira transversal instalada a 90 graus da esteira principal que conduzia a cana-de-açúcar para a moenda e um sistema de flap desviador, acionado por um volante, que está indicado na Figura 29. Esse sistema permitia carregar novamente no caminhão, através da esteira transversal, a mesma carga de cana-de-açúcar recebida e soprada, para se repetir o experimento e determinar o quanto ainda continha de impurezas mineral e vegetal. A Figura 30 apresenta a estação de limpeza a seco, com detalhe para a esteira transversal. 


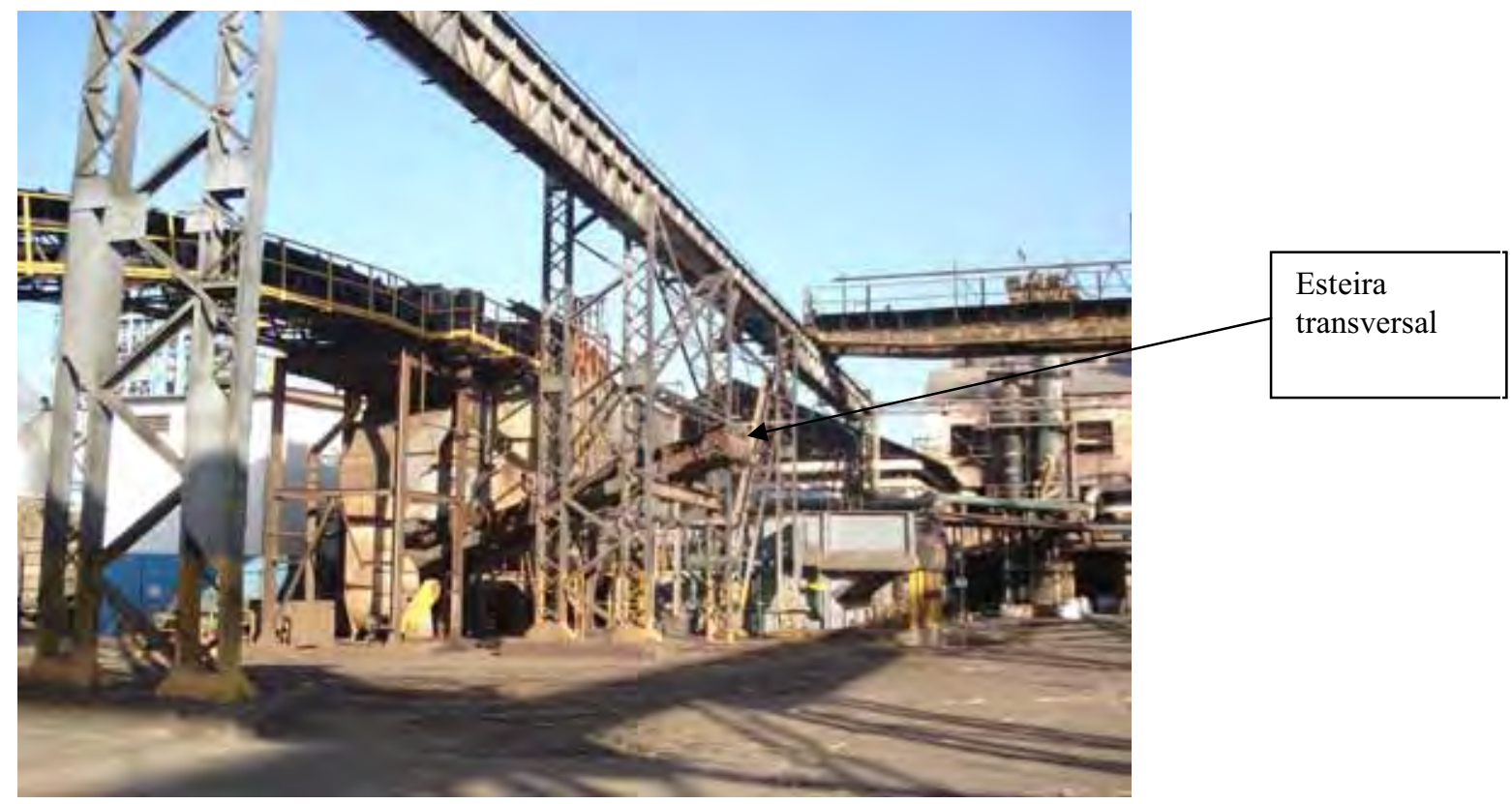

Figura 30 - Estação de limpeza a seco.

O experimento foi realizado nos setores agrícola e industrial da usina, com 16 repetições, com coletas de amostras no campo em tambores de capacidade 100 litros. Além da amostragem de campo com tambores, a amostragem com sonda oblíqua foi efetuada tanto na primeira como segunda sopragem. Na Figura 31, é apresentada a sonda oblíqua em operação amostrando uma carga de cana-de-açúcar picada.

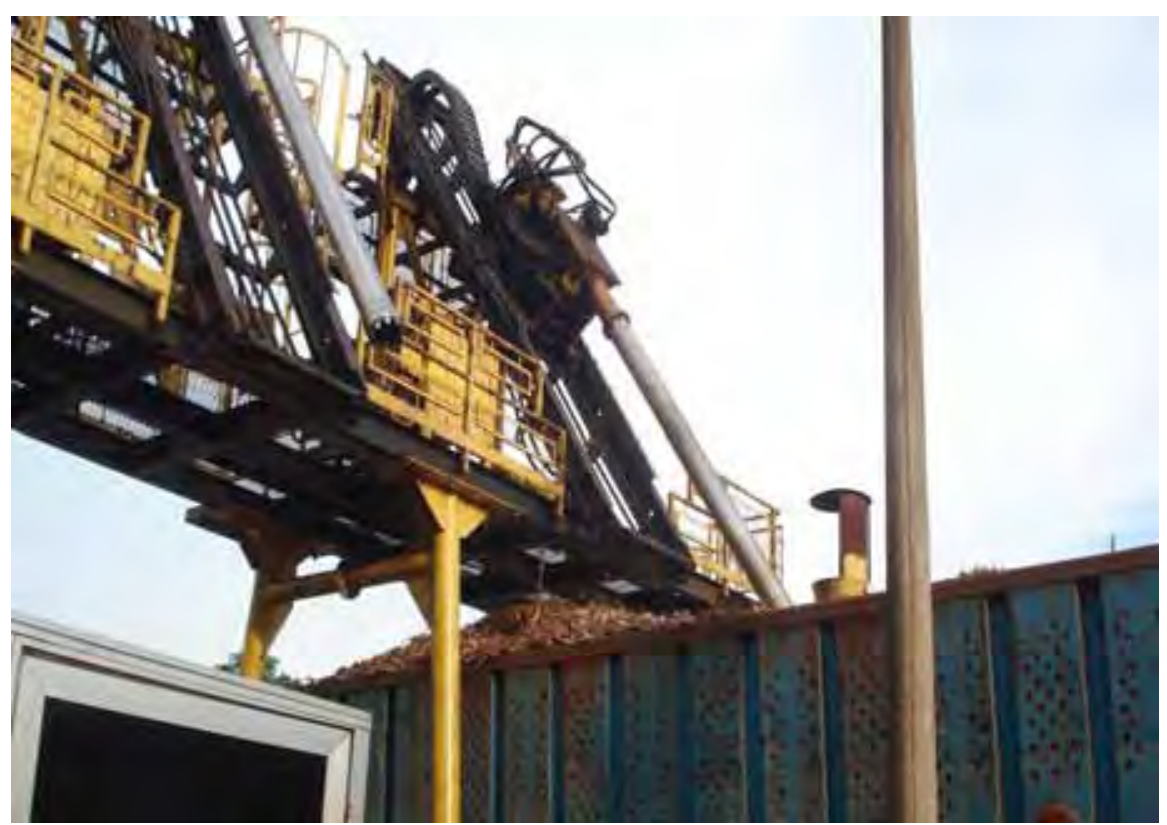

Figura 31 - Sonda oblíqua de amostragem de cana-de-açúcar em operação. 


\subsubsection{Determinação das impurezas totais e vegetais}

Foram coletadas amostras diretamente das cargas de cana-de-açúcar em recipientes de capacidade 100 litros, e também, através das sondas oblíquas de amostragem do Laboratório de pagamento de cana-de-açúcar pelo teor de sacarose (LPCTS). Essas amostras foram processadas separando-se colmos, impurezas e palhiço. O palhiço foi separado em folhas verdes e secas passíveis de serem separadas dos colmos através do jato de ar no sistema de separação.

Todas as amostras foram colocadas em baldes e pesadas em balança de precisão de $10 \mathrm{~g}(0,1 \%)$.

Os materiais utilizados para separação das impurezas foram lona plástica $(2 \mathrm{~m} \times 2 \mathrm{~m})$, escova de cerdas de nylon, peneira comum com abertura nominal de 4,0 $\mathrm{mm}$ e diâmetro de $70 \mathrm{~cm}$, peneira comum com abertura nominal de 2,0 $\mathrm{mm}$ e diâmetro de 50 $\mathrm{cm}$, balde plástico com capacidade para 60 litros com a tara marcada no próprio balde, baldes plástico com capacidade para 10 litros, pincel e faca.

As determinações das impurezas seguiram o método abaixo descrito:

. Colocar o balde com a amostra sobre a lona plástica ou sobre mesa apropriada para impurezas totais, devidamente limpa e seca, com o cuidado para não perder material;

. Limpar cada tolete com o auxílio da escova, deixando todas as impurezas sobre a lona plástica ou a mesa e os toletes limpos no balde de 60 litros;

. Retirar raízes que vem junto com a cana com o auxílio de uma faca;

. Retirar manualmente do material as impurezas de origem vegetal, inclusive as que estão agregadas nos entrenós, e colocá-las nos baldes de 10 litros de folhas secas e folhas verdes;

.Peneirar o restante do material primeiramente em peneira de abertura 4,0 $\mathrm{mm}$, procurando sempre tirar da parcela retida na peneira, as impurezas vegetais, colocando-as no balde de 10 litros onde já está o restante das impurezas vegetais. Os fragmentos de cana retidos na peneira devem ser colocados no balde contendo os toletes limpos;

. Peneirar o restante do material na peneira de abertura 2,0 mm;

. A parte retida na peneira colocada no balde contendo os toletes limpos; 
. O material que passou pela peneira com abertura de 2,0 $\mathrm{mm}$ deve ser colocado no balde de impureza mineral;

. Os "palmitos" devem ser considerados como cana, sendo deles retirados somente as palhas soltas ou queimadas.

. Pedaços de toletes dilacerados durante a amostragem devem ser colocados juntos com as canas limpas.

\subsubsection{Determinação das impurezas totais}

Apurada através da Eq. 9:

$$
I m=\frac{(p a-P c l)}{P a} .100
$$

Onde:

Im $=$ impureza total, $\%$;

$P a=$ peso da amostra, $\mathrm{g}$;

$P c l=$ peso da cana-de-açúcar limpa, g

\subsubsection{Determinação da impureza vegetal}

Apurada através da Eq. 10:

$$
I v=\frac{(P i v)}{P a} .100
$$

Onde:

$I v=$ impureza vegetal, $\%$;

$P a=$ peso da amostra, $\mathrm{g}$

$P i v=$ peso da impureza vegetal, $\mathrm{g}$

\subsubsection{Determinação da umidade média do palhiço}

Apurada através da Eq. 11:

$$
I m p=\frac{(U F v) \cdot(P F v)+(U F s) \cdot(P F s)}{P F v+P F s}
$$


Onde:

$U m p=$ umidade média do palhiço, $\%$;

$U F v=$ umidade folhas verdes, $\%$;

$U F s=$ umidade folhas secas, $\%$;

$P F v=$ peso das folhas verdes, $\mathrm{g}$;

$P F s=$ peso das folhas secas, $\mathrm{g}$

\subsubsection{Determinação da quantidade de palhiço a partir da amostra}

Apurada através da Eq. 12:

$$
Q p=P p a \cdot \frac{P l b}{100}
$$

Onde:

$Q p=$ quantidade de palhiço, $\mathrm{kg}$;

$P p a=$ percentual de palhiço da amostra, \%;

$P l b=$ peso líquido balança rodoviária, $\mathrm{kg}$ 


\section{RESULTADOS E DISCUSSÃO}

6.1 Avaliação dos métodos de recolhimento de palhiço de cana-de-açúcar no campo.

6.1.1 Recolhimento de palhiço com colhedora para forrageiras.

O experimento foi realizado durante toda a safra canavieira num período, de 195 dias e os resultados obtidos estão apresentados na Tabela 9.

Tabela 9 - Resultados obtidos no recolhimento de palhiço com máquina forrageira.

\begin{tabular}{lc}
\hline & $\begin{array}{c}\text { dados do } \\
\text { experimento }\end{array}$ \\
\hline palhiço recolhido $(\mathrm{t})$ & 17724,5 \\
\hline área de colheita $(\mathrm{ha})$ & 3583,61 \\
\hline produtividade de recolhimento $(\mathrm{t} / \mathrm{ha})$ & 4,95 \\
\hline combustível $(\mathrm{l} / \mathrm{t})$ & 3,62 \\
\hline umidade média $(\%)$ & 10,7 \\
\hline Impureza mineral $(\%)$ & 7,54 \\
\hline massa média transportada por viagem $(\mathrm{t})$ & 5,75 \\
\hline número de viagens & 3081 \\
\hline distância média $(\mathrm{km})$ & 15,7 \\
\hline custo de transporte por viagem $\mathrm{R} \$$ - (USD) & $96,17-(32,71)$ \\
\hline custo palhiço posto na usina $\mathrm{R} \$ \mathrm{t}-(\mathrm{USD} / \mathrm{t})$ & $58,14-(19,78)$ \\
\hline
\end{tabular}




\subsubsection{Produtividade média do recolhimento}

Considerando a média apurada pelo CTC - Centro de Tecnologia Canavieira de 14,06 t/ha de palhiço, em diversos experimentos (Tabela 6), o resultado obtido de 4,95 t/ha de palhiço recolhido (com umidade de 10,7\%), permite concluir que foram recolhidos em média $35 \%$ do palhiço disponível.

\subsubsection{Consumo de combustível}

O consumo de combustível foi 7\% maior no segundo experimento, isto pode ser explicada pela pior performance mecânica das máquinas forrageiras nesse experimento.

\subsubsection{Umidade média do palhiço}

A umidade média determinada no experimento $(10,7 \%)$ tem um valor energético elevado, PCI de $3731 \mathrm{kcal} / \mathrm{kg}$ ou $15620 \mathrm{~kJ} / \mathrm{kg}$, isso se deveu a insolação recebida no período ocorrido entre o recolhimento e colheita da cana-de-açúcar, que não foi item controlado no experimento. Devido à má performance mecânica da máquina forrageira, o recolhimento não seguiu o parâmetro estabelecido de ocorrer, até 4 dias da colheita da canade-açúcar, o que em média resultaria em umidade de $15 \%$.

\subsubsection{Impureza mineral}

A impureza mineral média apurada de $7,54 \%$ foi considerada elevada para o uso do palhiço como energético para as caldeiras, requerendo peneiramento para separação da terra, antes de ser misturado ao bagaço. O bagaço já tem em sua composição resíduo mineral, que somado ao do palhiço, causará entupimentos na caldeira.

\subsubsection{Massa média transportada por viagem}

Observou-se também que, devido à limitação da altura do braço de descarga da máquina forrageira, o transporte foi adaptado com carrocerias com 4,00 metros de altura total do solo, o que reduziu sua capacidade de carga, pois essa altura poderia ser até 4,40 metros, que é a autorizada pela legislação, e que poderia ter o volume aumentado, e também a massa de palhiço transportado por viagem cujo resultado obtido, foi de 5,75 t/viagem. 


\subsubsection{Custo do transporte por viagem}

$\mathrm{O}$ custo do transporte do experimento foi considerado elevado, e justificado em que, foi contratado um prestador de serviço do Uruguai, só que com um agravante, a máquina não foi submetida à manutenção adequada após a safra de sorgo e, com isso não apresentou a disponibilidade adequada para o serviço, sendo necessária a contratação de uma segunda máquina, que também apresentou alto índice de quebras, ou seja, necessitouse de duas máquinas para executar serviço necessário para uma. Como o restante dos equipamentos, tais como tratores e implementos para aleiramento e caminhões para transporte até a indústria, eram da própria usina e com custo fixo, a ociosidade do sistema aumentou o custo por tonelada transportada. O custo de transporte extraído da Tabela de Custos Operacionais da usina foi de $\mathrm{R} \$ 9,44$ por tonelada para raio médio de $20 \mathrm{~km}$, logo o custo de 5,75 t/viagem deveria ser R $\$ 54,28$ e não $\mathrm{R} \$ 96,17$ obtido.

\subsubsection{Custo do palhiço posto na usina}

Justificou-se pelo fato comentado no item 6.1.1.6, de que o custo fixo da estrutura, não se diluiu na ociosidade do sistema, e de que o experimento teve uma melhor apropriação de custos indiretos de administração das atividades.

\subsubsection{Avaliação qualitativa}

No experimento, numa avaliação qualitativa, verificou-se que o tempo de vida médio do jogos de facas e contra-facas da máquina, foi de 1000 t de palhiço recolhido, sendo que o melhor resultado se deu com a montagem das facas intercaladas, utilizando-se a metade das facas e com tempo médio de 4 horas para se efetuar a troca. No inicio a máquina operou num período de 470 horas, não apresentando falhas mecânicas que merecessem destaque. Estimou-se que tinha potencial para operar até 20 horas por dia, o que lhe daria eficiência de $83 \%$, com produção que possa atingir $200 \mathrm{t} /$ dia em solos arenosos e $150 \mathrm{t} / \mathrm{dia}$ em solos argilosos. Porém após a boa fase inicial, seguiram-se os problemas de desempenho mecânico da máquina, relatados no item 6.1.1.6. 


\subsubsection{Desempenho da máquina em solo arenoso e argiloso}

A Tabela 10 apresenta o desempenho da máquina, recolhendo palhiço em solo arenoso e solo argiloso, uma vez que a usina tem plantações nesses tipos de solos. Tabela 10-Resultados comparativos de recolhimento de palhiço em solo arenoso e solo argiloso

\begin{tabular}{lcc}
\hline & $\begin{array}{c}\text { Experimento: Fazenda Pujol } \\
\text { variedade RB 84-5257 } \\
\text { espaçamento 1,00 metro } \\
\text { solo arenoso }\end{array}$ & $\begin{array}{c}\text { Experimento: Fazenda Quebra Pote } \\
\text { variedade PO 86-1363 } \\
\text { espaçamento 1,40 metro } \\
\text { solo argiloso }\end{array}$ \\
\hline palhiço disponível no campo (t/ha.) & 14,67 & 13,9 \\
\hline palhiço recolhido (t/ha.) & 8,62 & 6,03 \\
\hline \% palhiço recolhido (\%) & 58,8 & 43,4 \\
\hline umidade do palhiço (\%) & 8 & 14,6 \\
\hline produtividade da forrageira $(\mathrm{t} / \mathrm{h}-\mathrm{h} / \mathrm{h})$ & $11,5-1,33$ & $7,14-1,18$ \\
\hline massa específica da carga $\left(\mathrm{kg} / \mathrm{m}^{3}\right)$ & 72,9 & 88 \\
\hline carga média $(\mathrm{t})$ & 3,935 & 4,7 \\
\hline tempo de carregamento $(\mathrm{minutos})$ & 20 & 40 \\
\hline tempo do ciclo $($ minutos $)$ & 120 & 130 \\
\hline distância média $(\mathrm{km})$ & 18 & 14 \\
\hline
\end{tabular}

\subsubsection{Desempenho da máquina em solo arenoso e argiloso}

O palhiço recolhido, superior em $35 \%$ e a produtividade em $61 \%$ também superior, no solo arenoso, justificou-se porque a máquina possui dispositivo detetor de metais muito sensível, que, em solos argilosos, que apresentam ferro em sua composição, desarma o alimentador da máquina com muita freqüência, reduzindo seu rendimento, e que também influenciou para que o tempo de carregamento fosse $100 \%$ maior no solo argiloso.

Em solo argiloso, houve a necessidade de um aumento na freqüência de limpeza da máquina, devido ao acúmulo de terra no picador e no lançador da mesma.

A diferença da massa específica está ligada diretamente à umidade do palhiço recolhido, que no caso do solo arenoso, recebeu mais tempo de insolação, após a colheita da cana-de-açúcar, e apresentou-se 6,6 pontos percentuais mais secos, que o palhiço recolhido no solo argiloso, o que também influenciou na carga média transportada.

O tempo maior do ciclo para o solo argiloso justificou-se, pelo maior tempo de carregamento, amenizado pela menor distância média. 


\subsubsection{Avaliação do processo de recolhimento com colhedora para forrageira.}

Essa modalidade de recolhimento de palhiço apresentou pontos positivos para a indústria porque é picado e carregado já com baixa umidade, em caminhões com carrocerias que facilitam seu descarregamento diretamente no pátio de bagaço, onde é misturado com o bagaço e conduzido para as caldeiras. Como pontos negativos estão à baixa densidade de carga, e o alto desgaste das facas e contra-facas das máquinas forrageiras, que tem que recolher o palhiço aleirado no solo, causando desgaste, sobretudo se mal regulada ou com o palhiço mal aleirado, recolhendo muita impureza mineral.

\subsubsection{Recolhimento de palhiço com colhedora "Twyster."}

A Tabela 11 apresenta os resultados do experimento realizado com a máquina "Twyster" recolhendo palhiço seco e verde.

Tabela 11 - Resultados de recolhimento de palhiço obtidos com a colhedora "Twyster" em condições da umidade.

\begin{tabular}{|c|c|c|c|c|c|c|c|c|}
\hline \multicolumn{3}{|c|}{ dados de colheita } & \multirow{2}{*}{$\begin{array}{c}\begin{array}{c}\text { produtividade } \\
\text { recolhimento }\end{array} \\
\mathrm{t} / \mathrm{ha} \\
\end{array}$} & \multirow{2}{*}{$\begin{array}{c}\text { massa } \\
\mathrm{kg}\end{array}$} & \multirow{2}{*}{$\begin{array}{c}\text { volume } \\
\mathrm{m}^{3}\end{array}$} & \multirow{2}{*}{$\begin{array}{c}\text { e massa } \\
\text { específica } \\
\mathrm{kg} / \mathrm{m}^{3}\end{array}$} & \multirow{2}{*}{\multicolumn{2}{|c|}{$\begin{array}{cc}\begin{array}{r}\text { umidade impureza } \\
\text { mineral }\end{array} \\
\% & \% \\
\end{array}$}} \\
\hline condição & $\mathrm{m}$ linear & $\mathrm{m}^{2}$ & & & & & & \\
\hline seca & 810 & 1215,0 & 4,83 & 587 & 10,5 & 55,46 & 13,92 & 3,41 \\
\hline verde & 747 & 1120,5 & 10,29 & 1153 & 10,5 & 108,94 & 40,82 & 6,19 \\
\hline
\end{tabular}

\subsubsection{Produtividade do recolhimento}

$\mathrm{Na}$ condição de palhiço seco, que é o mais desejável como combustível, a produtividade foi de 4,83 t/ha, contra 4,95 t/ha, do experimento com máquina forrageira, valor apenas $2 \%$ menor, com a vantagem de que, no experimento com a máquina “Twyster", não há a necessidade se efetuar a operação de aleiramento, pois a máquina recolhe o palhiço da maneira com fica no solo, após a colheita da cana-de-açúcar.

\subsubsection{Desempenho da máquina por característica de palhiço}

Para a condição verde do palhiço, são considerados justificáveis os maiores valores de produtividade, massa e massa especifica, uma vez que estão diretamente 
relacionados com a umidade, isto é, quanto mais úmido o palhiço, maior a sua massa específica. A produtividade da máquina com palhiço verde foi $113 \%$ superior ao palhiço seco, logo se deixarmos o palhiço secar na indústria, é mais vantajoso colhê-lo na condição úmida.

\subsubsection{Umidade do palhiço}

Os valores estão diretamente relacionados com o tempo de insolação recebido, após a colheita da cana-de-açúcar: a condição seca é para palhiço recolhido após 3 a 4 dias da colheita, já a condição verde, foi para palhiço recolhido em seguida à colheita da cana-de-açúcar. Comparativamente, com o valor apurado para o recolhimento com a máquina forrageira, está 3,22 pontos percentuais maior, porém ressalvado o menor período do experimento da "Twyster", onde o número de repetições das análise de umidade foi menor.

\subsubsection{Impureza Mineral}

O maior valor encontrado para o palhiço verde justificou-se, também, pela impureza mineral, que fica aderida ao palhiço logo após a colheita da cana-de-açúcar, causada pelo borrifo de caldo e matéria líquida das folhas verdes, quando cizalhadas pelo cortador da colhedora de cana-de-açúcar.

\subsubsection{Massa específica}

Foi determinada através da Eq.7 e a diferença entre os valor da condições seca e úmida, estão relacionadas com a quantidade de matéria liquida do palhiço úmido.

Observou-se no experimento os tempos de operação e a partir desses dados, estimou-se os valores de produtividade, para uma eficiência adotada de $83 \%$, ou seja, 20 horas/dia de trabalho. Os dados estão apresentados na Tabela 12. 
Tabela 12 - Rendimentos calculados para 20 horas de trabalho da colhedora Twyster.

\begin{tabular}{|c|c|c|c|c|}
\hline & \multicolumn{4}{|c|}{ rendimentos } \\
\hline & \multicolumn{2}{|c|}{ base úmida } & \multicolumn{2}{|c|}{ produtividade operação } \\
\hline & $\mathbf{t} / \mathbf{h}$ & $\mathbf{t} / \mathbf{2 0 h}$ & ha/20h & minutos \\
\hline$\overline{\text { palhiço seco }}$ & 1,76 & 30,20 & 7,30 & \\
\hline palhiço verde & 3,46 & 41,00 & 6,70 & \\
\hline tempo de recolhimento & & & & 20 \\
\hline tempo de transbordo & & & & 3 \\
\hline tempo de carregamento & & & & 3 \\
\hline tempo total $\mathrm{p} / \mathrm{vol} .10,5 \mathrm{~m}^{3}$ & & & & 26 \\
\hline
\end{tabular}

\subsubsection{Desempenho operacional dos equipamentos}

Os resultados indicaram que na melhor condição apurada (palhiço verde) a capacidade de recolhimento foi de $3,46 \mathrm{t} / \mathrm{h}$ por máquina, ou seja, $13 \%$ menor que o declarado pelo fabricante. Para palhiço na condição seca, o valor foi de $1,76 \mathrm{t} / \mathrm{h}$ que equivale a $44 \%$ da capacidade nominal informada. No experimento com máquina forrageira Class, a capacidade efetiva de recolhimento foi de $11,5 \mathrm{t} / \mathrm{h}$ para solo arenoso e $7,14 \mathrm{t} / \mathrm{h}$ para solo argiloso, para a condição seca.

Para determinação do custo do palhiço recolhido posto usina, foi considerada a proposta da empresa Deltamaq, fabricante dos equipamentos Twyster Press e Twyster Box, que atestava que um conjunto de 2 recolhedoreas e 3 transbordos produziria 8 toneladas/hora de palhiço recolhido. Foram considerados 2 recolhedoras Twyster Press com trator MF6350 e 3 conjuntos transbordo Twyster Box com trator VT885. Para transporte foi considerada a média de $10 \mathrm{t}$ por carga e distância média de $20 \mathrm{~km}$. Os valores foram obtidos da Tabela de Custos Operacionais praticados da usina e estão demonstrados na Tabela 13.

Tabela 13 - Custo do palhiço recolhido pelo sistema de máquinas Twyster.

\begin{tabular}{|c|c|c|c|c|c|c|}
\hline equipamento & $\begin{array}{l}\text { quanti- } \\
\text { dade }\end{array}$ & $\begin{array}{l}\text { usto unitáric } \\
\text { para } 8 \text { t/h } \\
R \$ / h\end{array}$ & $\begin{array}{l}\text { custo total } \\
\text { para } 8 \mathrm{t} / \mathrm{h} \\
\mathrm{R} \$ / \mathrm{h}\end{array}$ & $\begin{array}{c}\text { custo por } \\
\text { t/palhiço } \\
\text { R\$ }\end{array}$ & $\begin{array}{c}\text { custo } \\
\text { transporte } \\
\mathbf{R} \$ / \mathbf{t}\end{array}$ & $\begin{array}{c}\text { custo posto } \\
\text { na usina } \\
\mathrm{R} \$ / \mathbf{t}-(\mathrm{USD} / \mathrm{t})\end{array}$ \\
\hline Trator MF 6350 & 2 & 85,70 & 171,40 & 21,43 & & \\
\hline Trator VT8854 & 3 & 47,20 & 141,60 & 17,70 & & \\
\hline Twyster Press & 2 & 33,50 & 67,00 & 8,38 & & \\
\hline Twyster Box & 3 & 16,20 & 48,60 & 6,08 & & \\
\hline transporte & & & & & 9,44 & \\
\hline total & & 182,60 & 428,60 & 53,58 & & $63,02-(32,15)$ \\
\hline
\end{tabular}




\subsubsection{Custo do palhiço posto na usina}

O valor apurado R\$ 63,02 foi $8 \%$ superior ao custo do recolhimento por máquina forrageira do segundo experimento. Excluída a participação do custo de transporte, os valores apurados para a tonelada do palhiço recolhido, são respectivamente R\$ 53,58 para a Twyster, contra $\mathrm{R} \$ 48,03$ para a máquina forrageira, ou seja, 12\% maior.

\subsubsection{Recolhimento de palhiço com máquina colhedora e enfardadora.} e os de custos na Tabela 15.

Os resultados dos dados operacionais estão apresentados na Tabela 14

Tabela 14 - Resultados operacionais do recolhimento do palhiço com máquina enfardadora.

\begin{tabular}{cccc}
\hline $\begin{array}{c}\text { produtividade } \\
\text { de recolhimento/ } \\
\text { enfardamento } \\
\text { t/ha }\end{array}$ & $\begin{array}{c}\text { impureza } \\
\text { mineral } \\
\text { média } \\
\%\end{array}$ & $\begin{array}{c}\text { umidade } \\
\text { média }\end{array}$ & $\begin{array}{c}\text { massa } \\
\text { transporte } \\
\text { por carga } \\
\mathbf{t}\end{array}$ \\
\hline 6,89 & $\%$ & $\%$ & \\
\hline
\end{tabular}

\subsubsection{Produtividade do recolhimento}

Considerando a média apurada pelo CTC - Centro de Tecnologia Canavieira de 14,06 t/ha de palhiço, em diversos experimentos (Tabela 6), o resultado obtido de 6,89 t/ha de palhiço recolhido (com umidade de 16\%), permite concluir que foram recolhidos em média $49 \%$ do palhiço disponível. A produtividade de recolhimento dessa modalidade foi $39 \%$ superior que o da máquina forrageira e $43 \%$ superior que a máquina Twyster para a condição seca e $49 \%$ inferior para a condição úmida da Twyster.

\subsubsection{Umidade do palhiço}

O valor apurado foi considerado dentro da média para recolhimento no campo, uma vez que depende das horas de insolação recebida após a colheita da cana-deaçúcar e a operação de recolhimento, comparando com os dois experimentos do recolhimento com forrageira foi praticamente igual ao primeiro, e 5,3 pontos percentuais maior que o segundo, e 2,08 pontos percentuais maior que a condição seca do experimento com a máquina Twyster. 


\subsubsection{Impureza mineral}

Foi o maior valor apurado (8\%) entre os experimentos de recolhimento no campo, contra $3,41 \%$ da condição seca para a Twyster, e 7,54\% do segundo experimento com máquina forrageira. $\mathrm{O}$ alto índice de impureza mineral vai causar muito desgaste no equipamento de picação, pois o palhiço necessita antes, ser picado para passar por uma estação de peneiramento para retirada dessa impureza.

\subsubsection{Avaliação qualitativa operacional dos equipamentos}

A máquina recolhedora e enfardadora apresentou elevado índice de quebras mecânicas no pick-up recolhedor de palhiço.

Tabela 15 - Resultados econômicos do recolhimento do palhiço com máquina enfardadora.

\begin{tabular}{|c|c|c|c|}
\hline $\begin{array}{c}\text { palhiço recolhido } \\
\text { t } \\
\end{array}$ & $\begin{array}{c}\text { custo do recolhimento } \\
\mathrm{R} \$-\mathbf{R} \$ / \mathbf{t} \\
\end{array}$ & $\begin{array}{c}\text { custo do transporte } \\
R \$ / t \text { - } R \$ \text { viagem }\end{array}$ & $\begin{array}{c}\text { custo posto usina } \\
R \$ / t \text { - (USD/t) }\end{array}$ \\
\hline 4215,25 & $265434,45-62,97$ & $6,47-30,41$ & $69,44-(37,95)$ \\
\hline
\end{tabular}

\subsubsection{Custo do palhiço recolhido, posto na usina.}

$\mathrm{O}$ custo apurado foi o maior dentre as modalidades de recolhimento de palhiço no campo, respectivamente: máquina forrageira $\mathrm{R} \$ 58,14$, máquina Twyster $\mathrm{R} \$ 63,02$ e máquina enfardadora $\mathrm{R} \$ 69,44$.

Já para o custo de transporte, mesmo tendo uma média de carga por viagem menor que a da máquina forrageira $(5,75 \mathrm{t})$, consegue ter menor custo, porque se utiliza de veículos comerciais ou de transporte de cana-de-açúcar, comparado à modalidade da máquina forrageira que tem transporte dedicado.

\subsection{Resultados da otimização de sistema de separação do palhiço na indústria.}

Os dados das análises efetuadas nas amostras de cana-de-açúcar, coletadas pelos métodos do tambor e da sonda oblíqua, bem como os cálculos efetuados para determinação das eficiências, estão apresentados no apêndice deste trabalho. Os resultados obtidos antes das sopragens estão apresentados na Tabela 16. 
Tabela 16 - Resultados das amostras antes das sopragens.

\begin{tabular}{|c|c|c|c|c|c|c|c|}
\hline \multicolumn{8}{|c|}{ Antes das sopragens } \\
\hline \multicolumn{2}{|c|}{ Tratamentos caminhão } & \multirow{2}{*}{$\begin{array}{c}\text { carga } \\
\mathrm{kg} \\
\end{array}$} & \multicolumn{4}{|c|}{ palhiço } & \multirow{2}{*}{$\begin{array}{c}\text { umidade } \\
\text { média } \\
\%\end{array}$} \\
\hline rpm & número & & $\begin{array}{c}\text { tambor } \\
\% \\
\end{array}$ & $\begin{array}{c}\text { sonda } \\
\% \\
\end{array}$ & $\begin{array}{c}\text { tambor } \\
\text { kg }\end{array}$ & $\begin{array}{c}\text { sonda } \\
\text { kg }\end{array}$ & \\
\hline \multirow{7}{*}{900} & 1 & 22520 & 4,79 & 4,07 & 1078,71 & 916,56 & 42,32 \\
\hline & 2 & 22220 & 4,90 & 3,24 & 1089,61 & 718,82 & 41,51 \\
\hline & 3 & 20280 & 6,04 & 6,14 & 1224,78 & 1245,19 & 32,86 \\
\hline & 4 & 22020 & 4,74 & 8,57 & 1043,78 & 1886,01 & 40,79 \\
\hline & 13 & 15980 & 5,62 & 7,29 & 897,48 & 1164,14 & 44,56 \\
\hline & 14 & 16100 & 5,62 & 9,75 & 905,12 & 1569,57 & 43,59 \\
\hline & 15 & 16000 & 4,81 & 13,53 & 769,22 & 2164,76 & 44,98 \\
\hline 900 & 16 & 16920 & 5,18 & 8,97 & 875,75 & 1517,38 & 39,01 \\
\hline \multirow[t]{4}{*}{ média } & & 19005 & 5,21 & 7,69 & 985,56 & 1397,81 & 41,20 \\
\hline & 5 & 16980 & 10,58 & 8,46 & 1796,78 & 1435,75 & 36,92 \\
\hline & 6 & 15100 & 8,86 & 14,82 & 1337,97 & 2237,31 & 33,27 \\
\hline & 7 & 16540 & 9,43 & 10,85 & 1560,48 & 1793,76 & 29,54 \\
\hline \multirow[t]{4}{*}{650} & 8 & 13680 & 11,39 & 19,64 & 1557,71 & 2686,07 & 29,57 \\
\hline & 9 & 12160 & 14,63 & 15,75 & 1778,74 & 1914,59 & 43,54 \\
\hline & 10 & 10760 & 13,83 & 19,78 & 1488,20 & 2128,33 & 38,22 \\
\hline & 11 & 11420 & 13,12 & 16,77 & 1498,19 & 1915,13 & 39,57 \\
\hline 650 & 12 & 11880 & 13,00 & 12,47 & 1544,01 & 1480,84 & 43,64 \\
\hline média & & 13565 & 11,85 & 14,81 & 1570,26 & 1948,97 & 36,78 \\
\hline
\end{tabular}

\subsubsection{Apuração da quantidade de palhiço recebido}

Com o extrator da colhedora em $900 \mathrm{rpm}$, foram apuradas as médias do palhiço recebido junto com a cana-de-açúcar, como sendo: de 5,21\% pelo método do tambor e 7,69\% pelo método da sonda oblíqua. Com o extrator em $650 \mathrm{rpm}$, as médias foram, $11,85 \%$ e $14,81 \%$, respectivamente.

A quantidade de palhiço amostrada pela sonda oblíqua foi em média 2,48 pontos percentuais maior, que a amostrada pelo método do tambor, para o experimento com $900 \mathrm{rpm}$ e 2,96 pontos percentuais maior, com $650 \mathrm{rpm}$. Isto pode ser explicado pelo fato da sonda ser um método destrutivo, onde o caldo da cana-de-açúcar, resultado da ação mecânica de cisalhamento e dilaceramentos dos colmos, se adere ao palhiço, causando aumento de sua massa. 
Considerando-se a relação de resíduos/produção da Tabela 6 , cuja média é de $18,18 \%$ de palhiço disponível, dos resultados obtidos pelo método do tambor, pode-se afirmar que na rotação de $650 \mathrm{rpm}$ e $900 \mathrm{rpm}$, foram colhidos 29 e 65\% do palhiço disponível, respectivamente.

A média das cargas colhidas com o extrator da colhedora em 900 rpm, foi de $19005 \mathrm{~kg}$, consideradas as modalidades de amostragem com tambor e sonda oblíqua, indicam que a média de carga líquida de cana-de-açúcar limpa, foram 18019,4 kg e 17607,1 $\mathrm{kg}$, respectivamente. Já para a colhedora com o extrator em $650 \mathrm{rpm}$, a média das cargas foi $13565 \mathrm{~kg}$, e a média de cana limpa, $11994,7 \mathrm{~kg}$ e $11616,0 \mathrm{~kg}$

As cargas de números 9, 10, 11 e 12 da Tabela 16, foram as menores de cana-de-açúcar colhidas e as maiores em impureza vegetal agregada, isto demonstra a perda da capacidade de carga de cana-de-açúcar, quando se deseja maior quantidade de palhiço, considerado o volume fixo da carroceria do caminhão de transporte. A Figura 32 apresenta esta relação para modalidade de amostragem pelo tambor e a Figura 33 apresenta a relação na modalidade cana-de-açúcar amostrada pela sonda oblíqua.

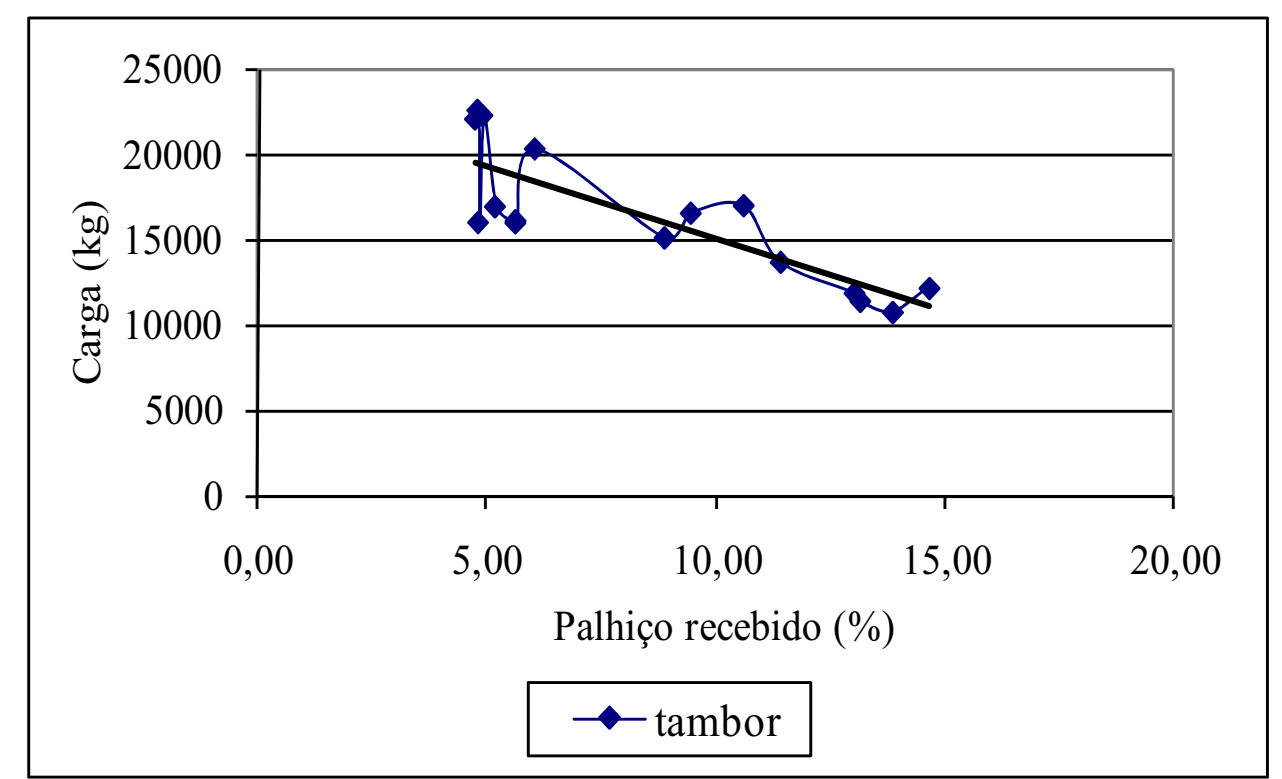

Figura 32 - Perda da capacidade de transporte em relação ao \% de palhiço colhido, amostra colhida em tambor. 


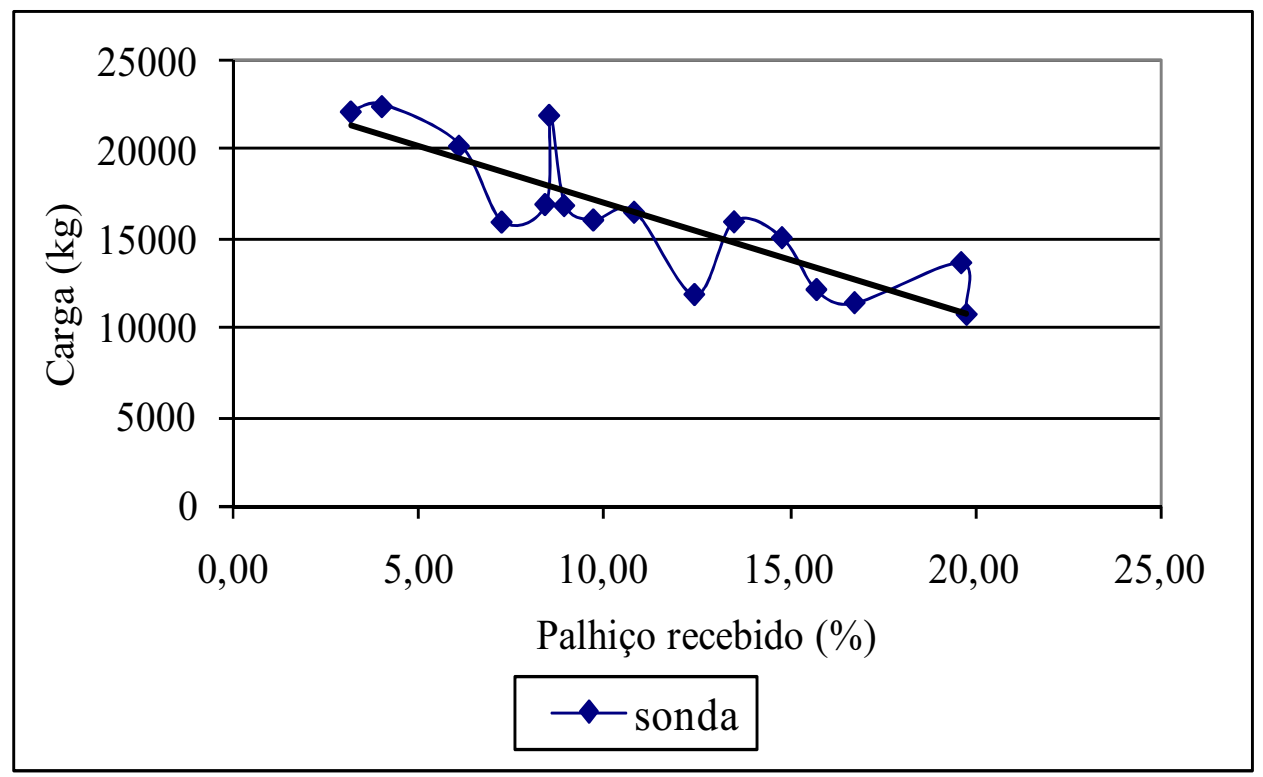

Figura 33 - Perda da capacidade de transporte em relação ao \% de palhiço colhido, amostra colhida pela sonda obliqua.

\subsubsection{Apuração da umidade média do palhiço recebido}

Determinada através da Eq. 11 foi apurado o valor de 38,99\%, muito próximo ao valor verificado no recolhimento pela máquina Twyster, na condição úmida que foi $40,82 \%$.

A diferença de 4,42 pontos percentuais, apurado nas médias de colheita como extrator nas rotações de 650 e $900 \mathrm{rpm}$, pode ser justificado como sendo que, na rotação de $900 \mathrm{rpm}$, a menor quantidade de palhiço, tem mais contato com os colmos de canade-açúcar, principalmente com o caldo resultante dos cortes.

\subsubsection{Apuração da eficiência do sistema de separação}

Os resultados apurados após a primeira sopragem estão apresentados na Tabela 17. 
Tabela 17 - Resultados obtidos após a primeira sopragem.

\begin{tabular}{|c|c|c|c|c|c|c|c|}
\hline \multicolumn{2}{|c|}{ Tratamentos caminhão } & \multirow{3}{*}{$\begin{array}{c}\text { carga } \\
\text { kg }\end{array}$} & \multicolumn{2}{|c|}{ palhiço } & \multirow{3}{*}{$\begin{array}{c}\text { umidade } \\
\text { média } \\
\%\end{array}$} & \multicolumn{2}{|c|}{ Palhiço soprado } \\
\hline & & & tambor & sonda & & tambor & sonda \\
\hline rpm & número & & $\%$ & $\%$ & & $\%$ & $\%$ \\
\hline \multirow{7}{*}{900} & 1 & 21660 & 1,58 & 2,04 & 44,28 & 68,31 & 51,79 \\
\hline & 2 & 21320 & 1,91 & 3,18 & 40,31 & 62,66 & 5,83 \\
\hline & 3 & 19420 & 2,32 & 5,45 & 31,80 & 63,25 & 15,08 \\
\hline & 4 & 21160 & 1,93 & 3,10 & 44,75 & 60,81 & 65,28 \\
\hline & 13 & 15120 & 1,88 & 2,24 & 59,28 & 68,38 & 70,91 \\
\hline & 14 & 14420 & 3,09 & 8,95 & 45,84 & 50,85 & 17,74 \\
\hline & 15 & 15240 & 3,66 & 7,92 & 48,56 & 27,50 & 44,22 \\
\hline 900 & 16 & 16280 & 2,92 & 7,44 & 47,81 & 45,63 & 20,14 \\
\hline \multirow[t]{4}{*}{ média } & & 18077,5 & 2,41 & 5,04 & 45,33 & 55,92 & 36,37 \\
\hline & 9 & 10900 & 3,81 & 6,51 & 48,51 & 76,63 & 62,97 \\
\hline & 10 & 9580 & 3,51 & 6,22 & 48,60 & 77,38 & 72,00 \\
\hline & 11 & 10220 & 3,40 & 4,86 & 51,25 & 76,79 & 74,09 \\
\hline \multirow[t]{4}{*}{650} & 12 & 11000 & 4,36 & 5,95 & 49,76 & 68,96 & 55,80 \\
\hline & 5 & 16060 & 4,20 & 6,98 & 44,47 & 62,45 & 21,94 \\
\hline & 6 & 14220 & 4,75 & 7,63 & 38,33 & 49,53 & 51,53 \\
\hline & 7 & 14020 & 3,67 & 6,17 & 34,81 & 67,03 & 51,78 \\
\hline 650 & 8 & 11140 & 4,16 & 9,16 & 34,72 & 70,29 & 62,03 \\
\hline média & & 12142,5 & 3,98 & 6,68 & 43,81 & 68,63 & 56,52 \\
\hline
\end{tabular}

Após a sopragem, as amostras colhidas, tanto pelo método do tambor como pelo da sonda oblíqua, indicaram a quantidade de palhiço ainda contido na cana-deaçúcar, como sendo para a rotação de $900 \mathrm{rpm}, 2,41$ e 5,04\% respectivamente, e para a rotação

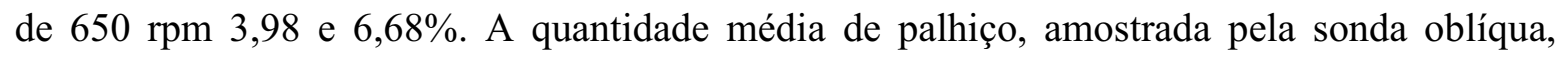
continua sendo maior que a amostrada pelo método do tambor, no caso 2,63 e 2,70 pontos percentuais para as rotações de 900 e $650 \mathrm{rpm}$.

A umidade média teve aumento de 5,58 pontos percentuais, isto pode ser explicado, por maior contato do palhiço com os colmos cortados em toletes, que nos manejos de carga, perdem caldo.

Os resultados do palhiço soprado, amostrado pelo método do tambor, apresentaram-se mais consistentes, que os amostrados pelo método da sonda oblíqua, quando comparados com as médias.

Os resultados apurados, após a carga de cana-de-açúcar passar pela segunda sopragem, estão expressos na Tabela 18. 
Tabela 18 - Resultados obtidos após a segunda sopragem.

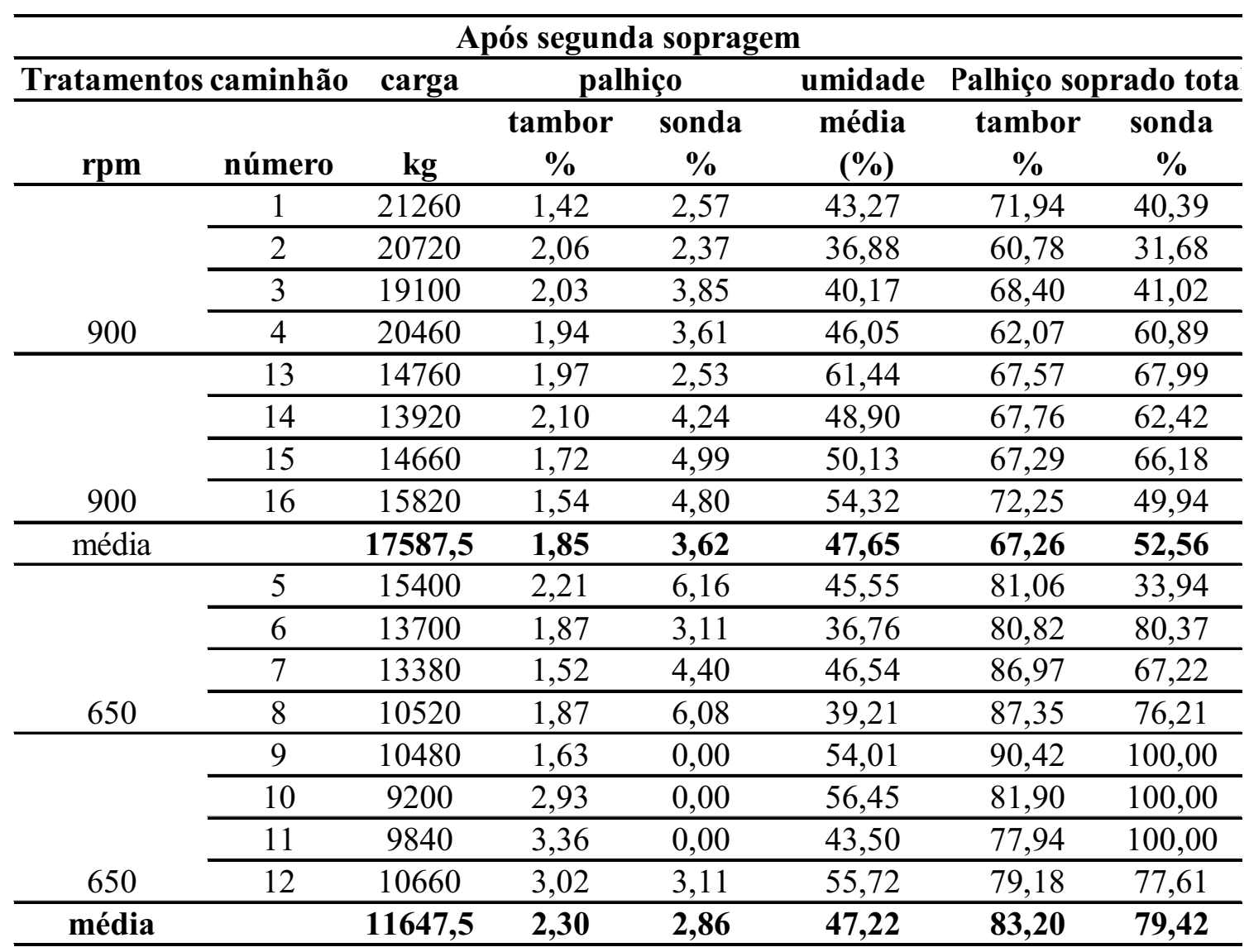

Após a segunda sopragem, ainda restaram 1,85\% de palhiço colhido com $900 \mathrm{rpm}$ e 2,30\% de palhiço, quando a rotação do extrator da colhedora estava com 650 rpm quando analisados pelo método do tambor. Quando a amostra foi colhida pela sonda oblíqua os valores são 3,62 e 2,86\% respectivamente. A relação entre as médias dos pesos da cana-de-açúcar limpa e após a segunda sopragem indica que, 3,26\% (492,5 kg) do material limpo ainda eram constituídos de palhiço e impureza mineral. Para comparação com a canade-açúcar recebida, 10,24\% (1667,5 kg) eram impurezas minerais e vegetais.

A impureza vegetal média amostrada pela sonda obliqua continuou sendo maior que a amostrada pelo método do tambor, no caso 1,17 pontos percentuais, porém observou-se que nas cargas 9, 10 e 11 a sonda não amostrou impureza vegetal, contra amostras expressivas registradas pelo método do tambor.

As médias obtidas do percentual de palhiço soprado, pelos dois métodos, se mostraram mais próxima, porém observou-se que, como o resultado do residual 
de palhiço, após segunda sopragem, pelo método da sonda oblíqua foi zero, a fórmula empregada calculada pela Eq. 8 determina que o palhiço fosse $100 \%$ soprado, o que o valor apurado pelo método do tambor contradiz.

A umidade média apurada do palhiço foi 2,86 pontos percentuais maiores que a obtida na primeira sopragem e 8,44 pontos percentuais maiores que a registrada quando do recebimento da cana-de-açúcar.

$\mathrm{O}$ efeito da segunda sopragem causou um incremento de 12,95 pontos percentuais, no sistema de separação de palhiço, resultado obtido pelo método do tambor,

A Figura 34 apresenta graficamente, os resultados do método do tambor.

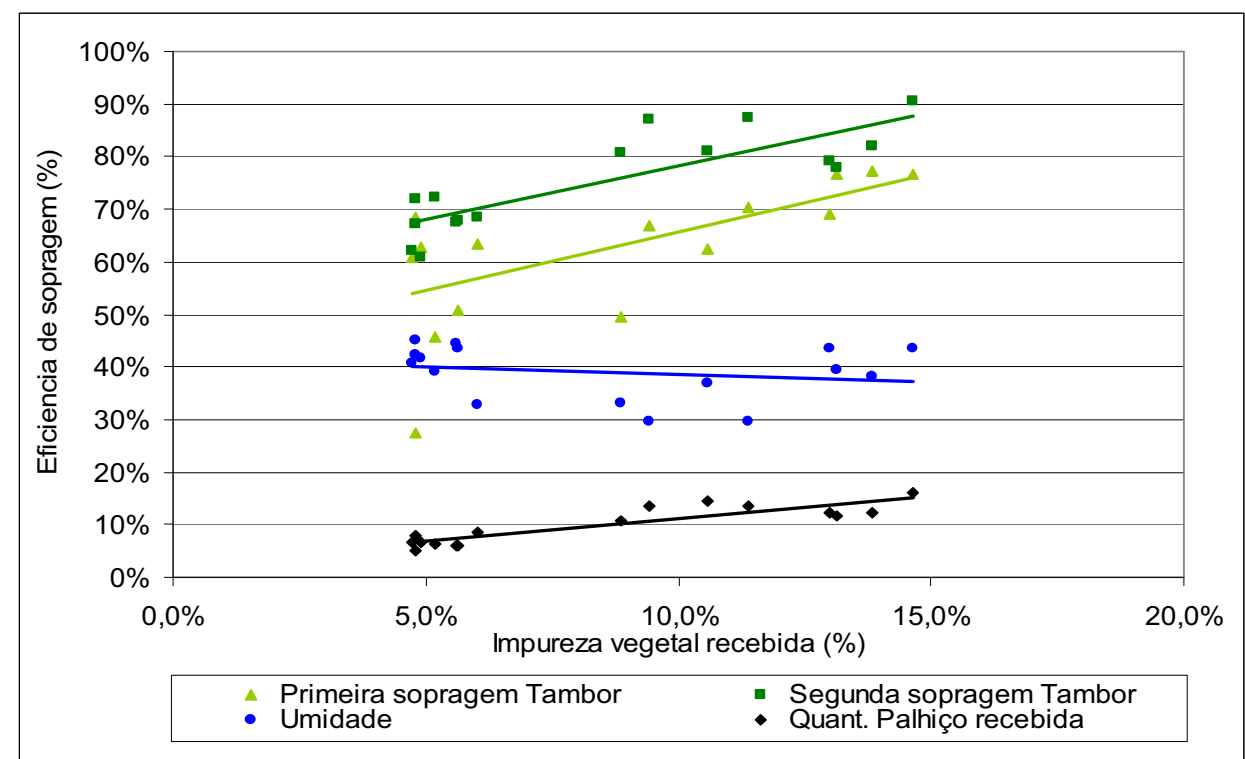

Figura 34 - Resultados de eficiência de separação de palhiço na indústria, pelo método do tambor.

A diferença entre o residual de palhiço da primeira para a segunda sopragem de $0,56 \%$ para método do tambor e $900 \mathrm{rpm}$ e 1,68 para $650 \mathrm{rpm}$ resultando num valor médio de $1,12 \%$, apresenta o seguinte resultado energético: O sistema de separação está calculado para receber $500 \mathrm{t} / \mathrm{h}$ de cana-de-açúcar colhida parcialmente integral. $\mathrm{O}$ valor de $1,12 \%$ de palhiço não separado significa o equivalente a $5600 \mathrm{~kg} / \mathrm{h}$ de palhiço, que aplicados como combustível misturado ao bagaço e ainda considerando o mesmo PCI do bagaço a 50\% de umidade, consegue gerar $11760 \mathrm{~kg}$ de vapor na caldeira de $67 \mathrm{Bar}$ de pressão e $525^{\circ} \mathrm{C}$ de temperatura. No processo de condensação, para a situação de vapor relatada, a turbina do 
gerador de energia elétrica, consome $4 \mathrm{~kg}$ de vapor para gerar $1 \mathrm{kWh}$, logo os $11760 \mathrm{~kg}$ de vapor, produzem em uma hora $2940 \mathrm{~kW}$. A potência do ventilador de sopragem é de $100 \mathrm{cv}$ e a da esteira de cana $60 \mathrm{cv}$, o que resultam em $117,7 \mathrm{~kW}$ de potência instalada para um segundo estágio de sopragem, resultando em sobra líquida de potência de $2822,3 \mathrm{~kW}$, o que justifica a instalação de um segundo estágio de sopragem em linha.

Da Figura 34, se conclui também que é maior a eficiência de separação, quanto maior o volume de palhiço, porém deve-se ponderar que também quanto maior o volume de palhiço, menor a quantidade de cana-de-açúcar transportada no mesmo veículo. Isso vai refletir no dimensionamento de transporte de cana-de-açúcar e o conseqüente aumento de custos de transporte tanto da cana-de-açúcar quanto do palhiço.

$O$ custo de corte, carregamento e transporte da usina, durante o experimento, foi de R \$19,75 por tonelada de cana-de-açúcar. Logo vem a ser também o custo do palhiço que é colhido, junto com a cana-de-açúcar em percentuais menores que $6 \%$. Os custos da operação de separação do palhiço na indústria foram estimados em R\$11,00/t, considerando-se o custo do palhiço pronto para ser queimado nas caldeiras em $\mathrm{R} \$ 30,75 / \mathrm{t}$.

A Figura 35, apresenta os resultados de separação do palhiço na indústria, pelo método da sonda oblíqua. A Figura 36 apresenta a comparação entre os métodos.

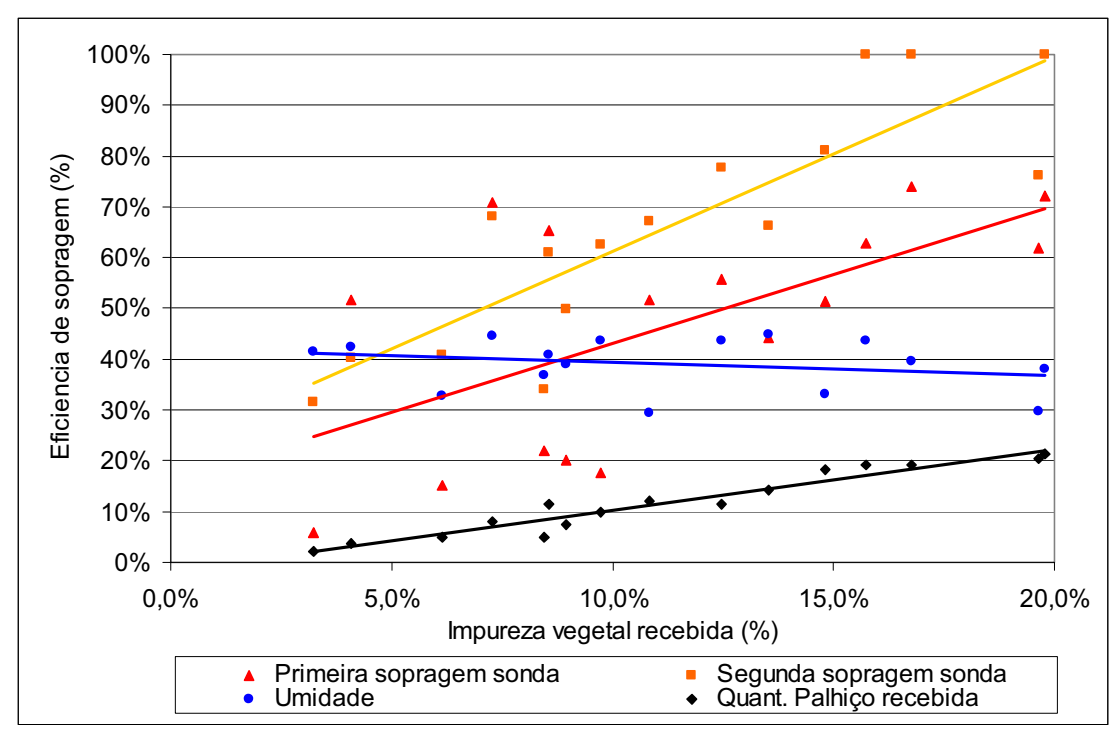

Figura 35 - Resultados de eficiência de separação pelo método da sonda oblíqua. 
A umidade do palhiço se apresenta da mesma forma, como no método do tambor.

As curvas de tendência linear, da primeira e segunda sopragens, apresentam incremento de eficiência.

Também no método da sonda oblíqua, quanto maior a quantidade de palhiço maior a eficiência de separação.

O segmento de reta da segunda sopragem apresenta-se distorcido em razão dos 3 valores iguais a $100 \%$.

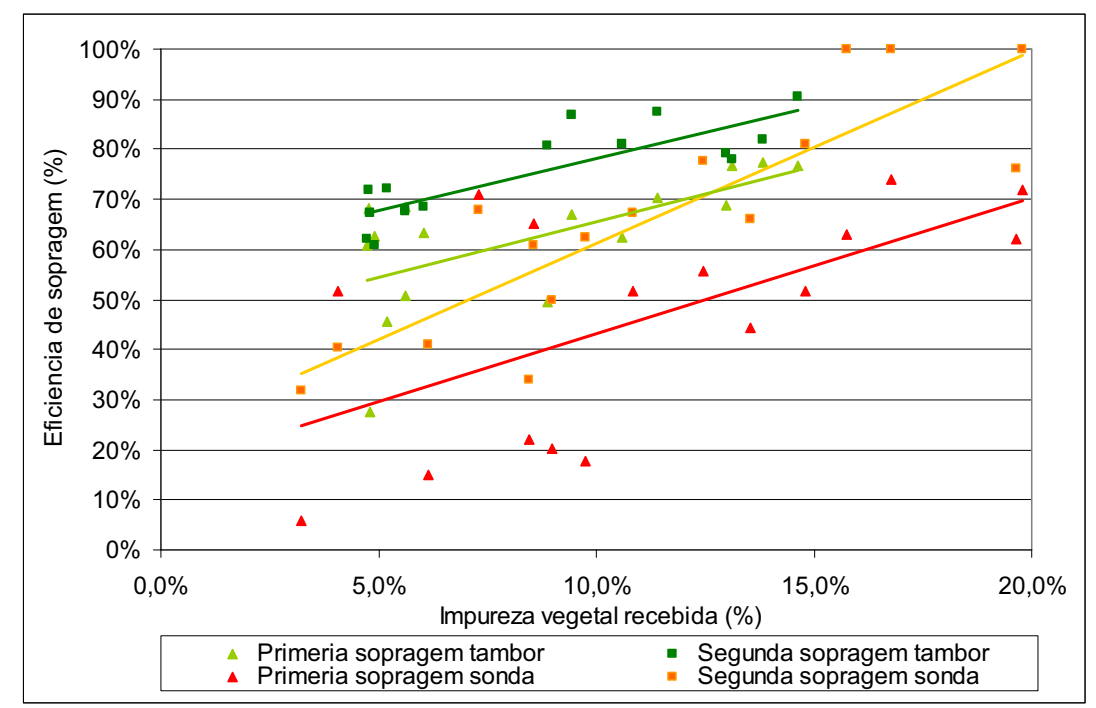

Figura 36 - Eficiência de separação do palhiço pelos métodos tambor e sonda oblíqua.

As curvas de tendência linear obtidas apresentam o melhor resultado para as coletas amostradas pelo método do tambor, mas ambas representam a melhor eficiência quando a cana-de-açúcar passa pelo processo de limpeza, por duas vezes.

$\mathrm{O}$ método de amostragem pelo tambor apresenta resultados menos dispersos que o método da sonda oblíqua.

\subsubsection{Impureza mineral recebida e separada}

As Figuras 37, 38 e 39, apresentam os valores de impureza mineral recebida com a cana e após as sopragens. 


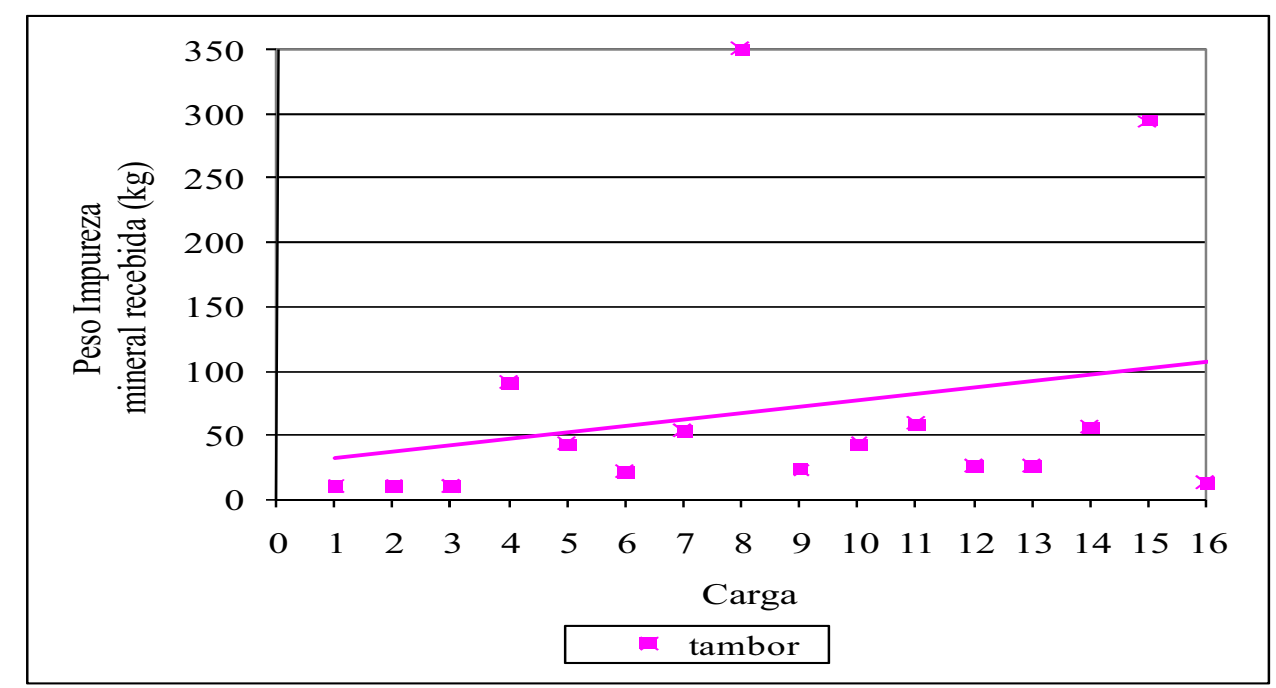

Figura 37 - Impureza mineral recebida com a cana-de-açúcar (método do tambor).

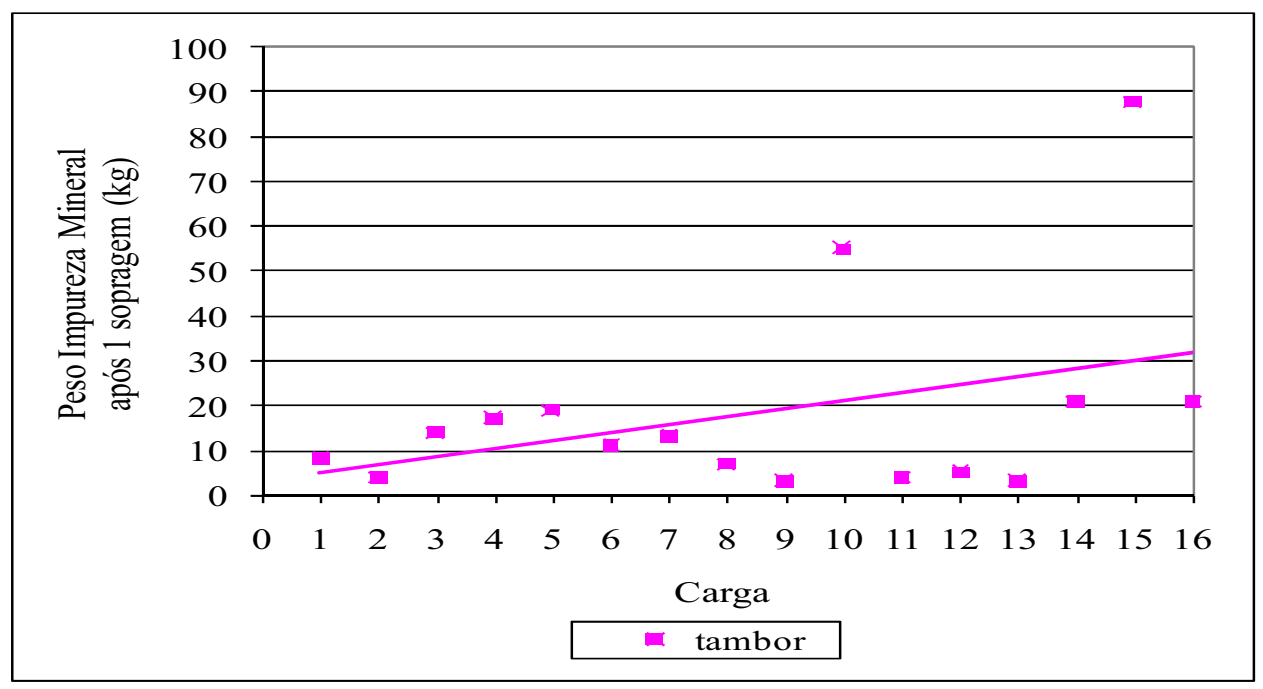

Figura 38 - Impureza mineral após a primeira sopragem (método do tambor). 


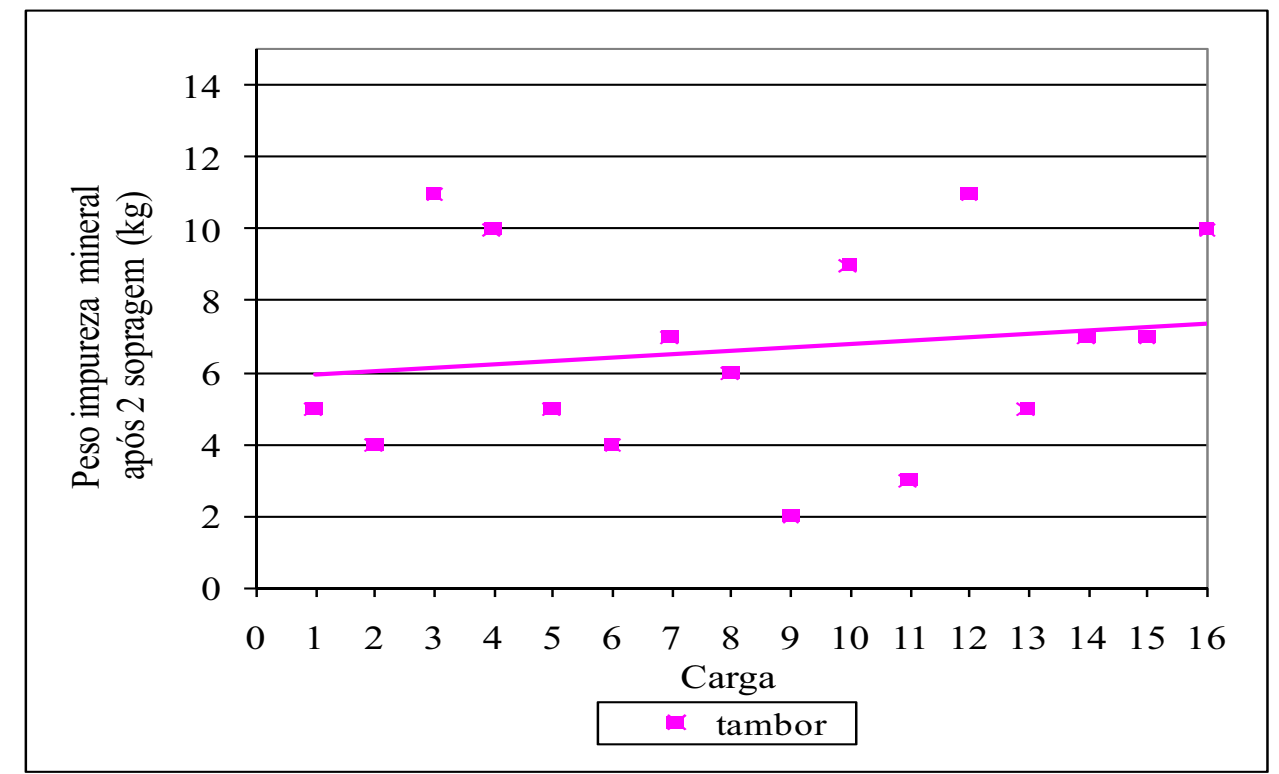

Figura 39 - Impureza mineral após a segunda sopragem (método do tambor).

Pode-se verificar comparando as Figuras 37, 38 e 39, de que aproximadamente $110 \mathrm{~kg}$ de impureza mineral por tonelada de cana-de-açúcar recebida, o efeito da sopragem foi muito benéfico, pois na primeira sopragem o valor residual obtido foi de aproximadamente $32 \mathrm{~kg}$ e 7,5 $\mathrm{kg}$ na segunda sopragem, resultando em pouca impureza para ser separada por peneiramento dinâmico, comparativamente com as quantidades verificadas nas modalidades de recolhimento do palhiço no campo. 


\section{CONCLUSÕES}

Verificados os resultados das duas modalidades de colheita de palhiço, concluiu-se de que os três sistemas de recolhimento de palhiço no campo, após a colheita da cana-de-açúcar, apresentaram custo mais elevado do que a colheita conjunta dos colmos e do palhiço, (colheita denominada de parcialmente integral) e posterior separação na indústria pelo sistema de limpeza a seco, sendo que o maior custo foi para o sistema que recolhia e enfardava o palhiço que apresentou custo de $\mathrm{R} \$ 69,44 / \mathrm{t}$ contra $\mathrm{R} \$ 30,75 / \mathrm{t}$ que foi o custo apurado para o sistema de limpeza a seco.

Para o sistema de recolhimento do palhiço no campo realizado por máquina para forrageiras, verificou-se que foi o custo elevado do transporte de $\mathrm{R} \$ 96,17$ por viagem, que contribuiu para que o custo da tonelada de palhiço colocada na Usina fosse elevado. Como a umidade do palhiço foi menor nos sistemas de recolhimento no campo, se minimizado for o custo do transporte, pode ser que se viabilize essa alternativa, uma vez que o Poder Calorífico Inferior do palhiço seco é bem maior que o do palhiço úmido, implicando em redução de combustível para a caldeira. O desempenho do sistema de recolhimento do palhiço no campo foi pior em solos argilosos do que em solos arenosos, pois a argila se agregou as partes móveis da máquina, causando paradas para limpeza. 
Para as duas modalidades, conclui-se da necessidade de peneiramento do palhiço recolhido ou separado, para retirada da impureza mineral, prejudicial ao processo de fabricação da Usina, o que seria um agravante para o sistema que recolhia e enfardava palhiço, pois essa impureza mineral tende a causar desgaste nos picadores necessários para picar os fardos.

Na modalidade de colheita parcialmente integral, concluiu-se de que quanto maior a quantidade de palhiço, maior foi a eficiência de separação, que teve incremento de $13 \%$ quando efetuada uma segunda sopragem, o que levou a um balanço energético positivo de $2822 \mathrm{~kW}$, porém como agravante, houve redução na capacidade de carga e transporte de até $30 \%$, quando se aumentou a quantidade de palhiço colhido junto com a cana-de-açúcar de 7\% para 13\%, isso pode implicar em aumento de frota e conseqüente aumento de custo do transporte da cana-de-açúcar dos canaviais até a Usina. 


\section{REFERÊNCIAS BIBLIOGRÁFICAS}

ARRIGONI, E.B. Uso de defensivos agrícolas. In: A energia da cana-de-açúcar - Doze estudos sobre a agroindústria da cana-de-açúcar no Brasil e a sua sustentabilidade. São Paulo: Berlendi Editores Ltda., 2005. cap. 8, p. 143-157

BRASIL. Ministério das Minas e Energia. Bioeletricidade, Portaria $n^{\circ} 384$, de 22/08/2005. Disponível em: $\leq$ http://www.mme.gov.br>. Acesso em: 10 set. 2005. BRAUNBECK, A.O. Jornal da Unicamp, Disponível em: $<$ http://www.unicamp.br/unicamp_hoje/ju/ju/2001/unihoje_ju164pag18.html>.Acesso em: 14 nov. 2005.

CENTRO DE TECNOLOGIA CANAVIEIRA - COPERSUCAR. Biomass power generation sugar cane bagasse and trash. Piracicaba, 2005. 1 CD-ROM.

COGENSP-ASSOCIAÇÃO DA INDÚSTRIA DE COGERAÇÃO DE ENERGIA.

Bioeletricidade- energia disponível e renovável com oferta assegurada e sustentada, Disponível em:<http:www.cogen.com.br/workshop/2007/Bioeletricidade_TR8_Propostas_CogenSP_050 92007.pdf>. Acesso em: 24 jun.2008.

COGENSP-ASSOCIAÇÃO DA INDÚSTRIA DE COGERAÇÃO DE ENERGIA.

Bioeletricidade- disponibilidade, potencial e perspectivas de expansão da oferta, Disponível 
em:

$<$ http://www.cogen.com.br/workshop/2008/Bioeletricidade_Forum_Canal_Energia_25032008 .pdf $>$. Acesso em: 24 jun.2008.

COGENSP-ASSOCIAÇÃO DA INDÚSTRIA DE COGERAÇÃO DE ENERGIA. Semana franco-brasileira de biocombustiveis, Dísponivel em:

$<$ http://www.cogensp.com.br//sem_Franco_bras_cogenSP_16062008.pdf $>$. Acesso em: 20 fev.2009.

COGENSP-ASSOCIAÇÃO DA INDÚSTRIA DE COGERAÇÃO DE ENERGIA.

Bioeletricidade- reduzindo emissões e agregando valor ao Sistema Elétrico Nacional,

Disponível em:

$<$ http://Cogensp.com.br/workshop/2009/Bioeletricidade_Agregando_Valor_Matriz_Elétrica_03jun2009.pdf $>$. Acesso em: 23 mai.2009.

HASSUANI, S. J. Ambiente Brasil, Desprezada, palha pode dobrar energia. Disponível em: $<$ http://www.valeverde.org.br/html/clipp2.phd?id=3531\&categoria=Energia $>$. Acesso em: 15 nov. 2005.

MACEDO, N.O. et al. Congresso de Iniciação Científica da UFSCar, X, Monitoramento de populações e controle da cigarrinha-da-raiz da cana-de-açúcar. Disponível em:

$<$ http://ufscar.br/jornada/ixcic/programa.htm>. Acesso em: 20 fev.2005.

PAES, L. A. D. Ambiente Brasil. Desprezada, palha pode dobrar energia. Disponível em: $<$ http://www.valeverde.org.br/html/clipp2.phd?id=3531\&categoria=Energia $>$. Acesso em: 15 nov. 2005.

PAES, L.A.D. Limpeza de cana a seco. In: SEMINÁRIO TECNOLOGIA DE LIMPEZA DE CANA A SECO, CTC Centro de Tecnologia Canavieira, Piracicaba ,2007. 1 CD-ROM PAES, L. A. D. Uso de defensivos agrícolas. In: A energia da cana-de-açúcar - Doze estudos sobre a agroindústria da cana-de-açúcar no Brasil e a sua sustentabilidade. São Paulo: Berlendi Editores Ltda., 2005. cap. 3, p.73-86.

PROINFA. PROGRAMA DE INCENTIVO AS FONTES ALTERNATIVAS DE ENERGIA ELETRICA, Lei $n^{\circ} 10.438$ de 26/04/2002. Disponível em: <http://www.camara.gov.br>>. Acesso em: 10 out.2005.

SÃO PAULO. Secretaria do Meio Ambiente. Lei $n^{\circ} 11.241$ de 19/09/2002. Disponível em: $<$ http://www.cetesb.sp.gov.br/sma>. Acesso em: 15 set. 2005. 
SÃO PAULO. Secretaria do Meio Ambiente. Decreto $n^{\circ} 47.700$ de 11/03/2003. Disponível em: <http://www.cetesb.sp.gov.br/sma>. Acesso em: 15 set. 2005.

SÃO PAULO. Secretaria do Meio Ambiente. Decreto $n^{\circ} 49.391$ de 21/02/2005. Disponível em: <http://www.cetesb.sp.gov.br/sma>. Acesso em: 15 set. 2005.

SÃO PAULO. Secretaria do Meio Ambiente. Protocolo agroambiental. Disponível em: $<$ http://www.cetesb.sp.gov/noticentro/2008/03/10_protocolo_apresentação.pdf.>. Acesso em: 15 jan.2009.

SÃO PAULO. Secretaria do Meio Ambiente. Projeto ambiental estratégico etanol verde.

Disponível em:

$<$ http://www.homologa.ambiente.sp.gov/etanolverde/relatório_etanol_verde_2009.pdf.>. Acesso em: 15 jun.2009.

RIPOLI, T.C.C. Recuperação da palha para fins energéticos. In: II WORKSHOP TECNOLÓGICO SOBRE COLHEITA DE CANA-DE-AÇÚCAR E PALHA PARA PRODUÇÃO DE ETANOL. Disponível em: <http://apta.sp.gov.br/cana/anexos/ppaper>. Acesso em: 14 fev 2009.

RIPOLI, T.C.C.; RIPOLI, M.L.C. Biomassa de cana-de-açúcar: colheita, energia e ambiente, Piracicaba, Ed. Barros \& Marques, 2004. 302 p.

RESENDE, A. S. Agrolink. Queima na cultura de cana-de-açúcar - Uma reflexão histórica, Disponível em:

$<$ http://www.portbusiness.com.br/colunistas/pg_detalhe_coluna.asp?col+864>. Acesso em: 15 nov. 2005.

SPENCER, G. L; MEADE, G. P. Manual del azucar de caña. Barcelona: Montaner y Simon S.A., Editores, 1967. $9^{\mathrm{a}}$ Ed., 939 p. 
APÊNDICE 
Apêndice 1 - Comparação dos dados métodos tambor e sonda obliqua.

\begin{tabular}{|c|c|c|c|c|c|}
\hline \multicolumn{2}{|c|}{ Número do teste: } & \multicolumn{2}{|l|}{1} & Caminhāo & 65014 \\
\hline & & Tambor & - Agricola & Sond & - Indústria \\
\hline Situacăo & $\begin{array}{l}\text { Peso } \\
\text { liquido }\end{array}$ & $\begin{array}{c}\% \text { palhiço na } \\
\text { amostra }\end{array}$ & $\begin{array}{c}\text { Peso da palhiço } \\
\text { no caminhăo }\end{array}$ & Impureza & Peso da palhiço \\
\hline Antes de & & & & & \\
\hline soprar & 22520 & $4,79 \%$ & 1078 & $4,07 \%$ & 917 \\
\hline $\begin{array}{l}\text { Apos } \\
\text { sopro }\end{array}$ & 21660 & $1,58 \%$ & 342 & $2,04 \%$ & 442 \\
\hline Após $2^{\circ}$ & 21260 & & 302 & 2570 1 & \\
\hline & & & & & 546 \\
\hline
\end{tabular}
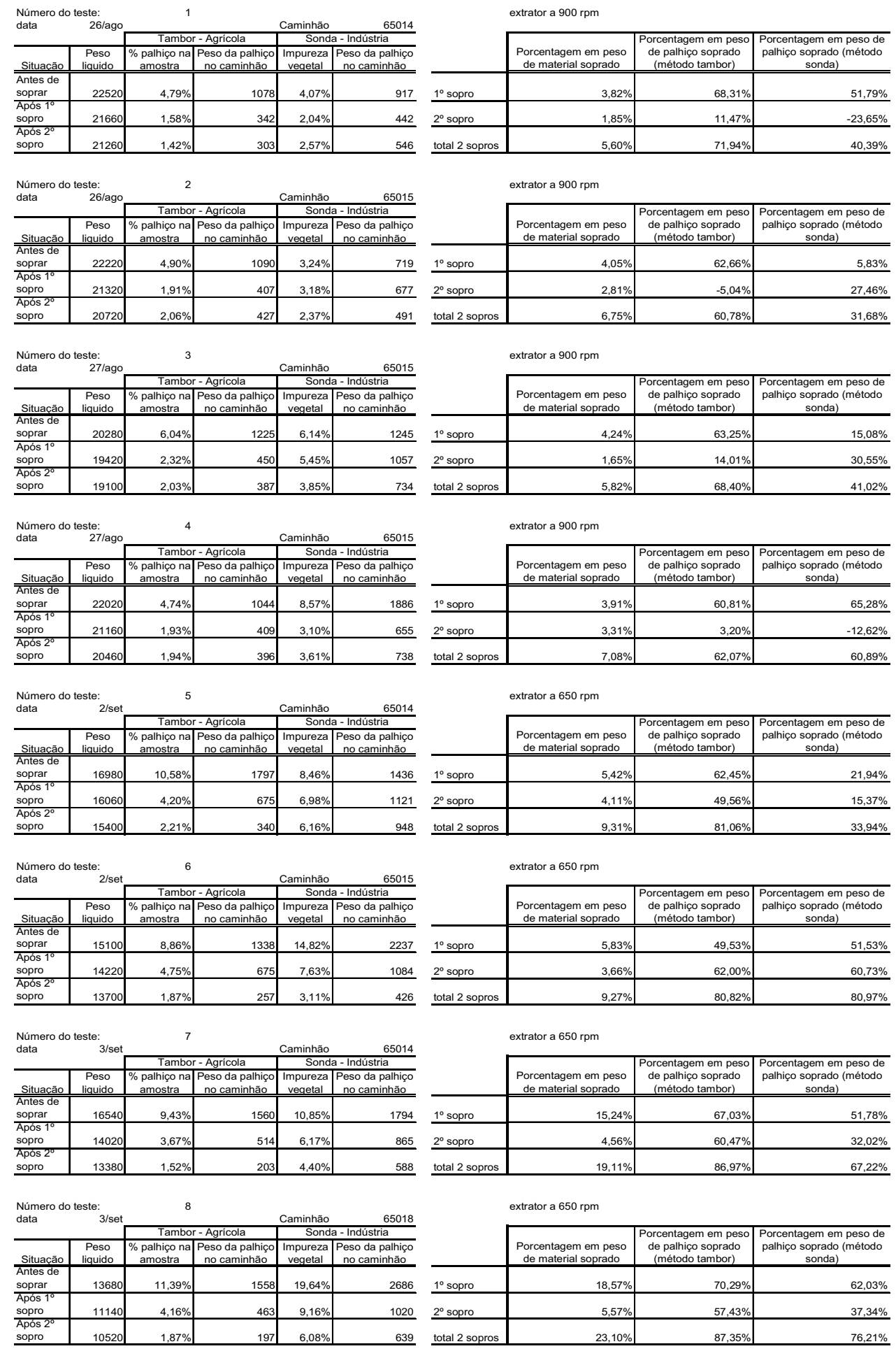
Continuação.
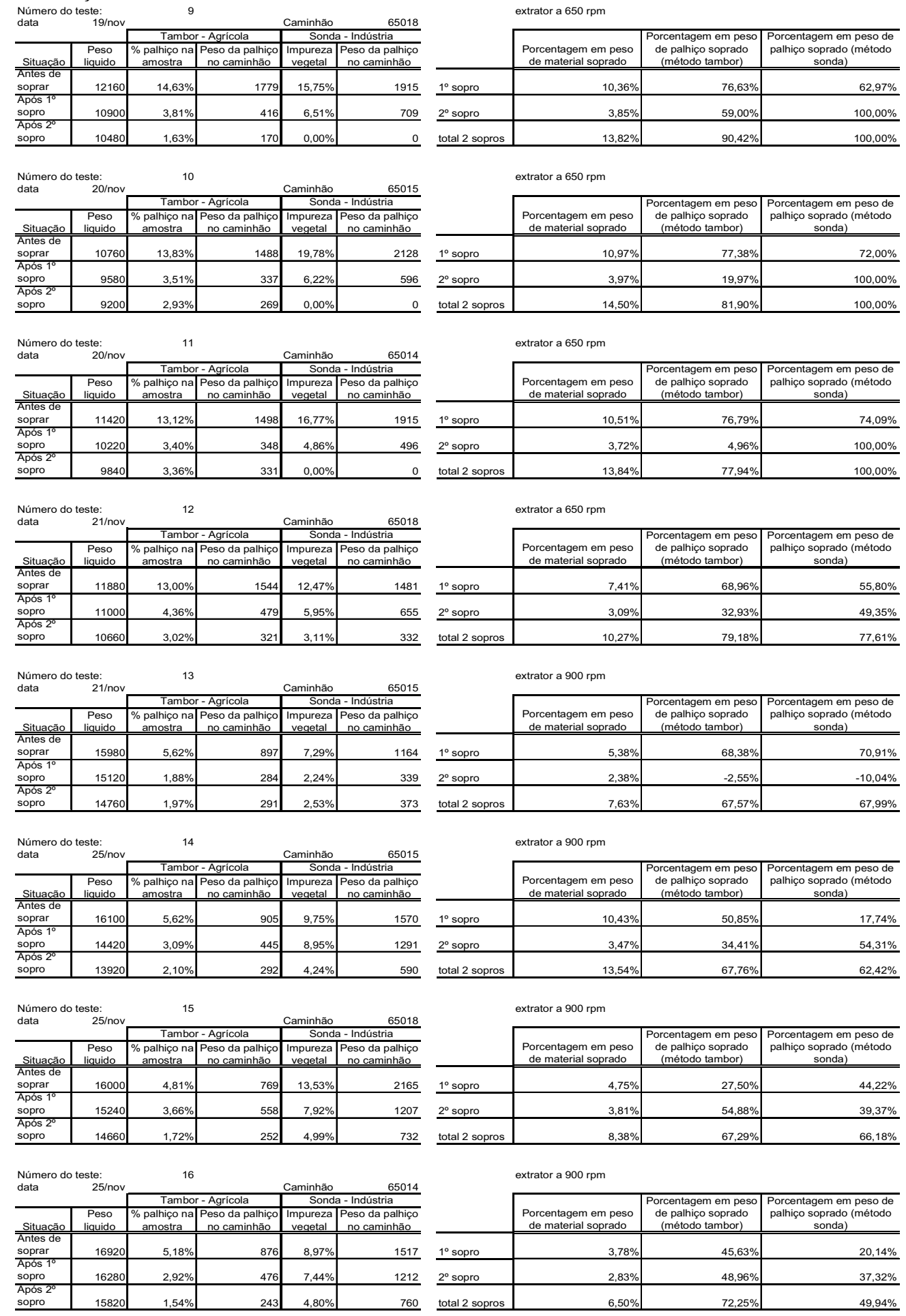


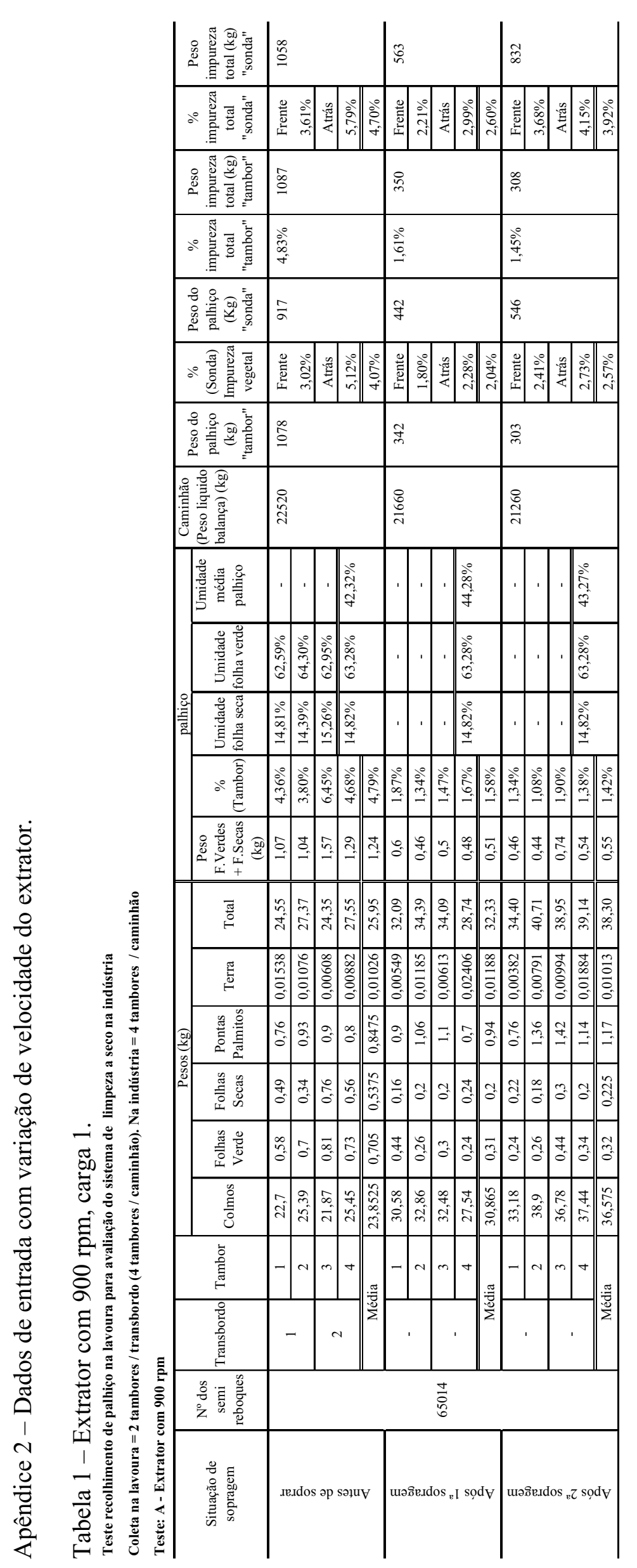




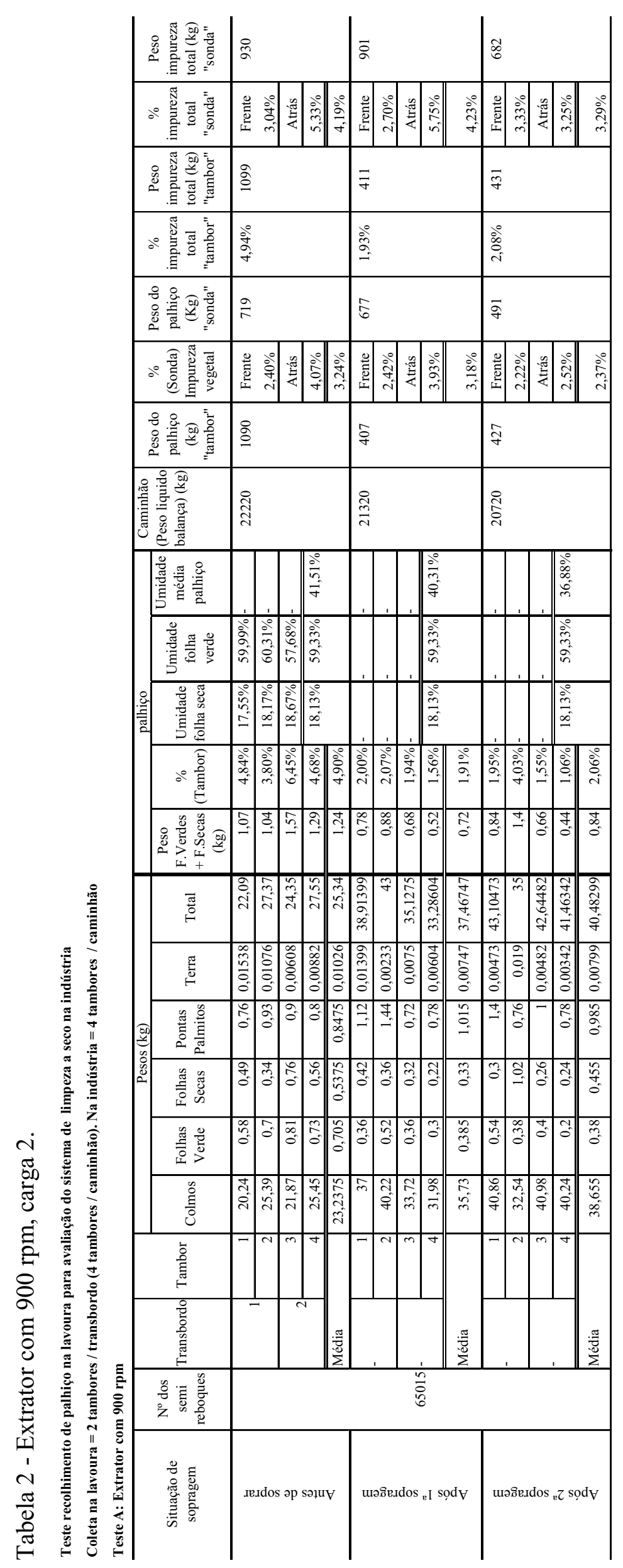




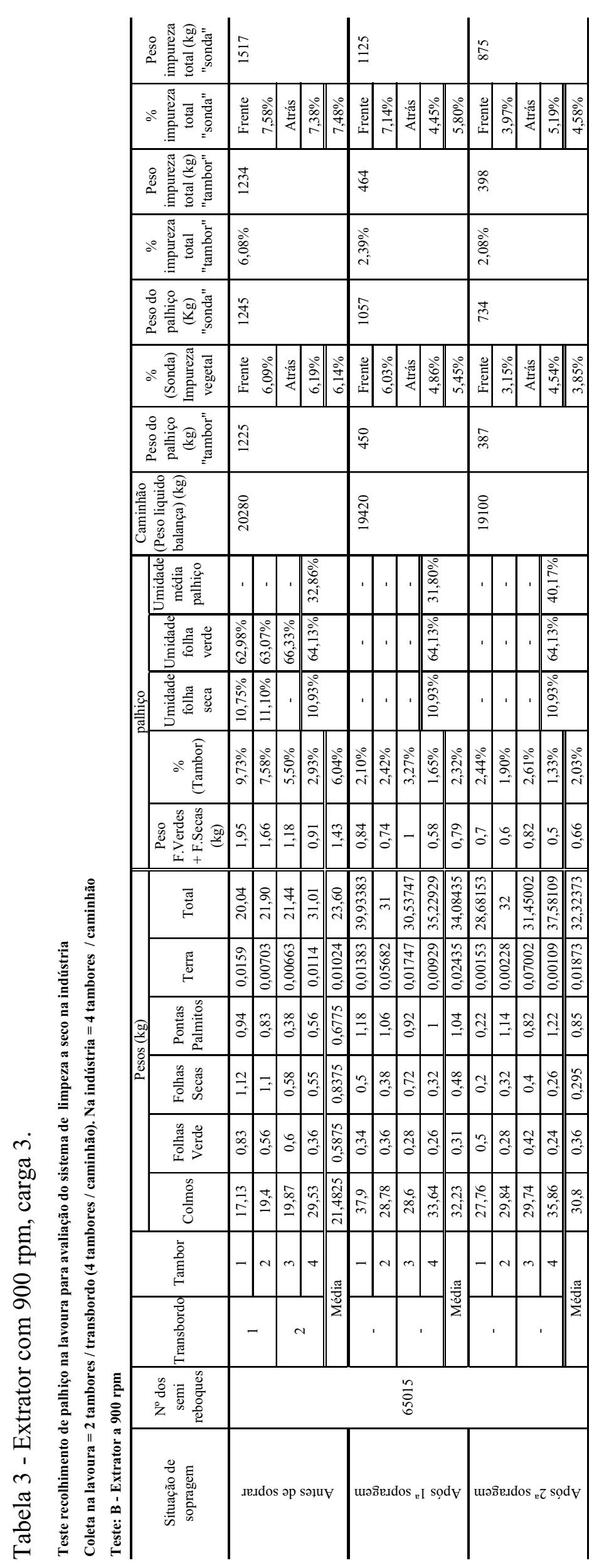




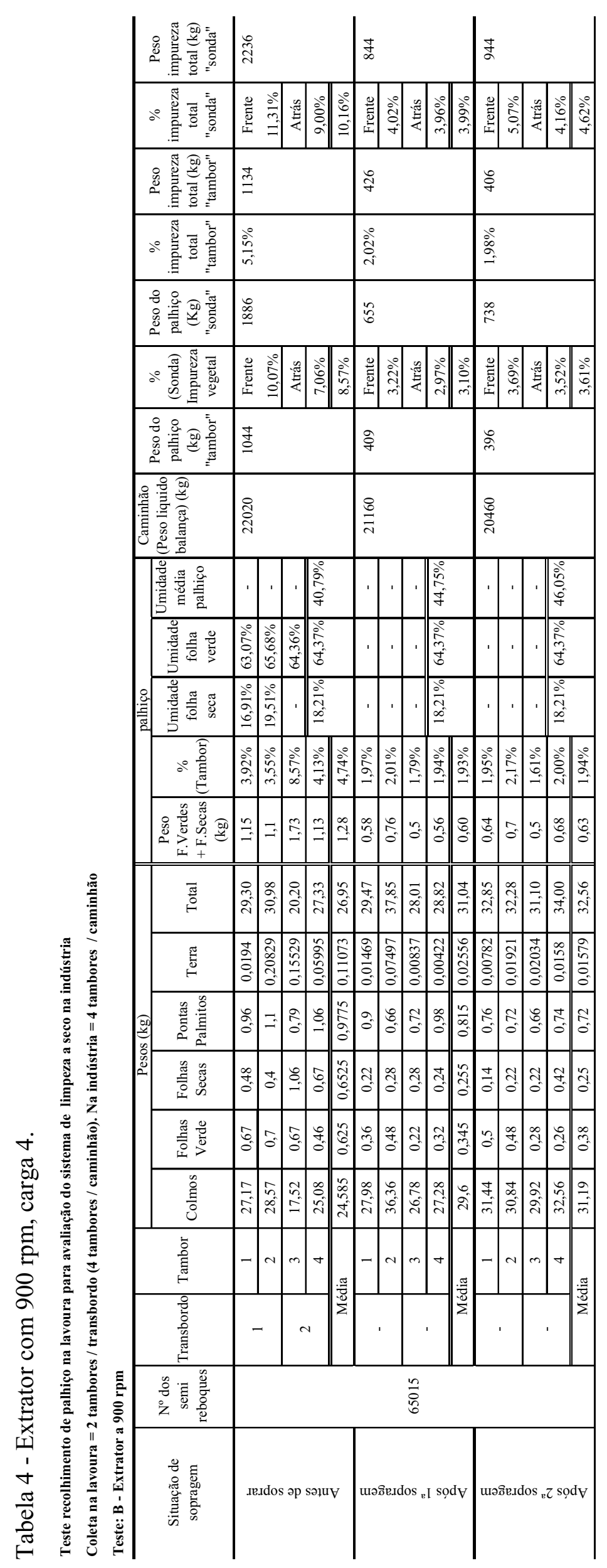




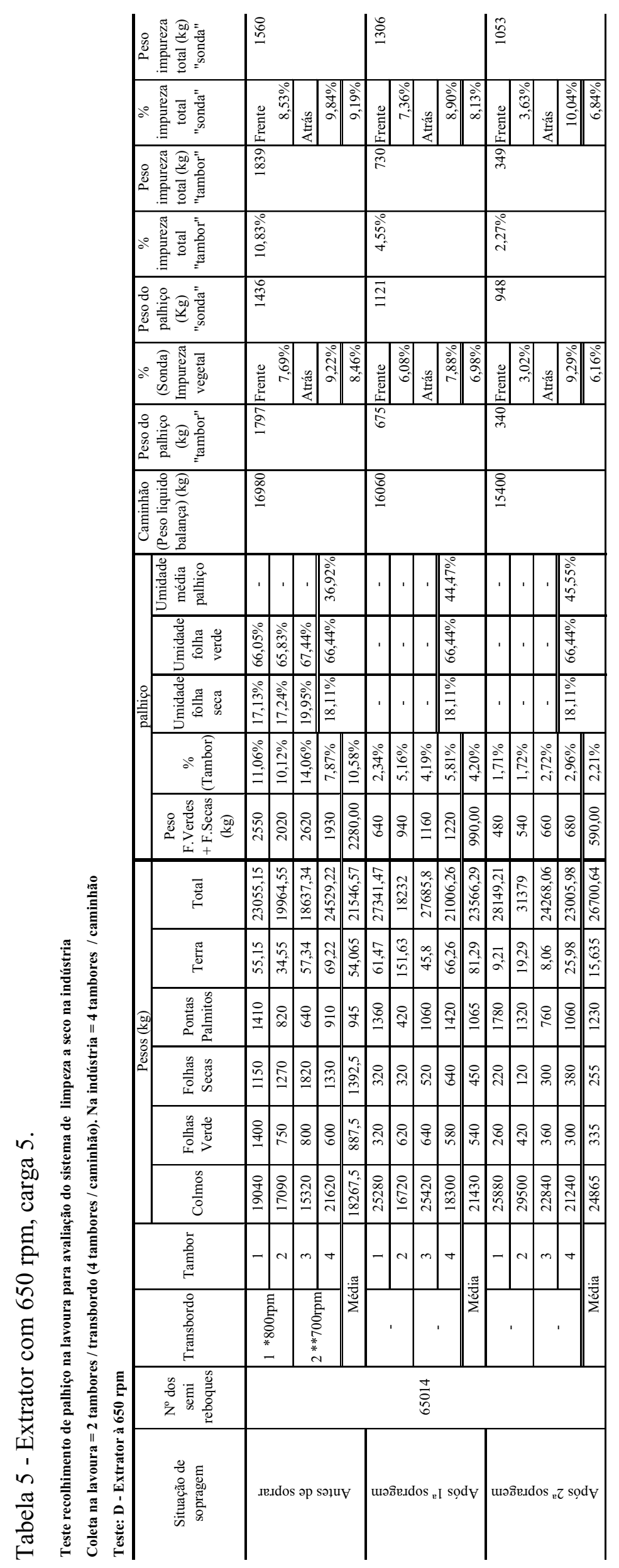




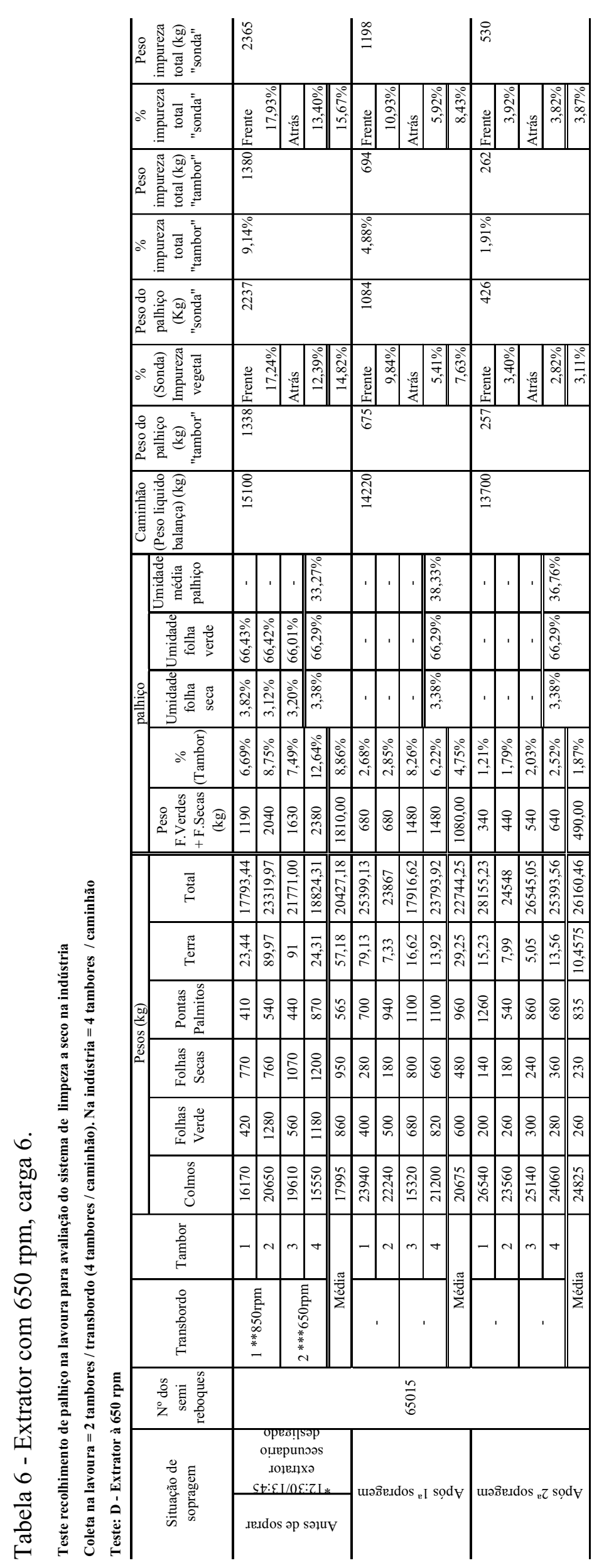

83 


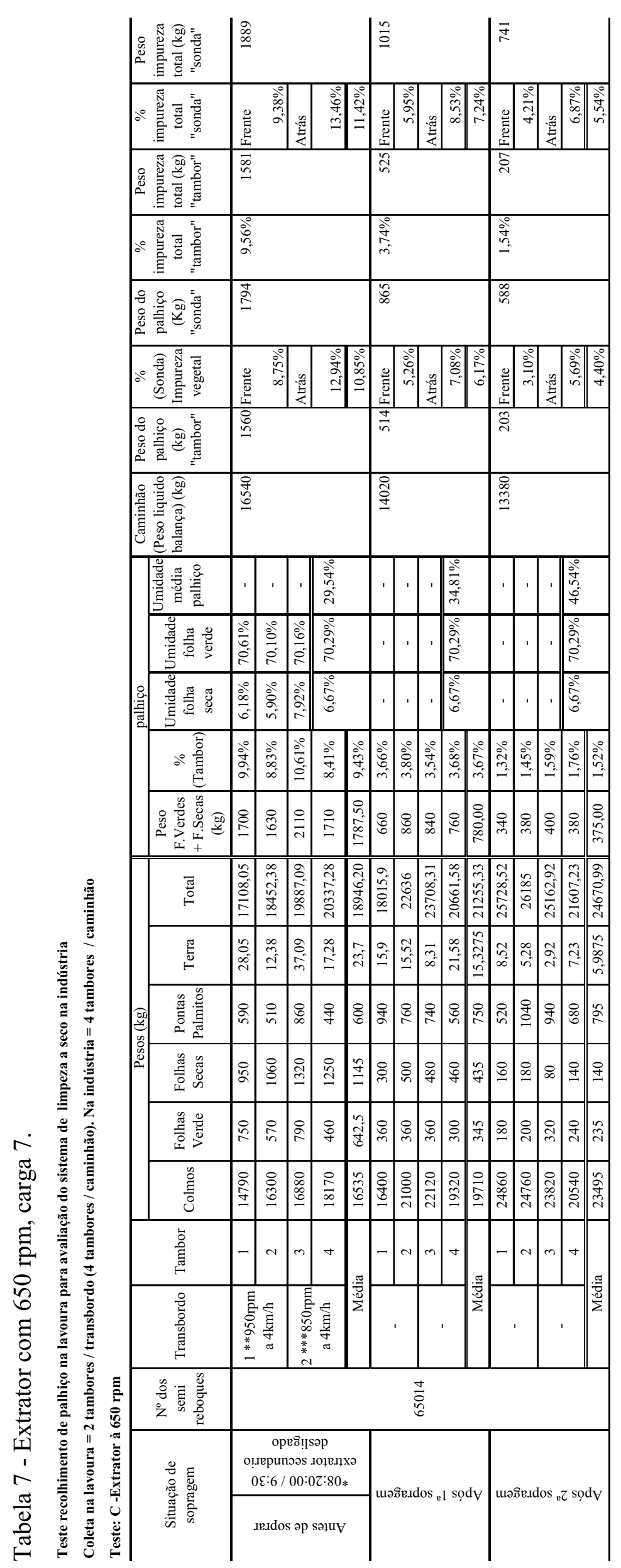




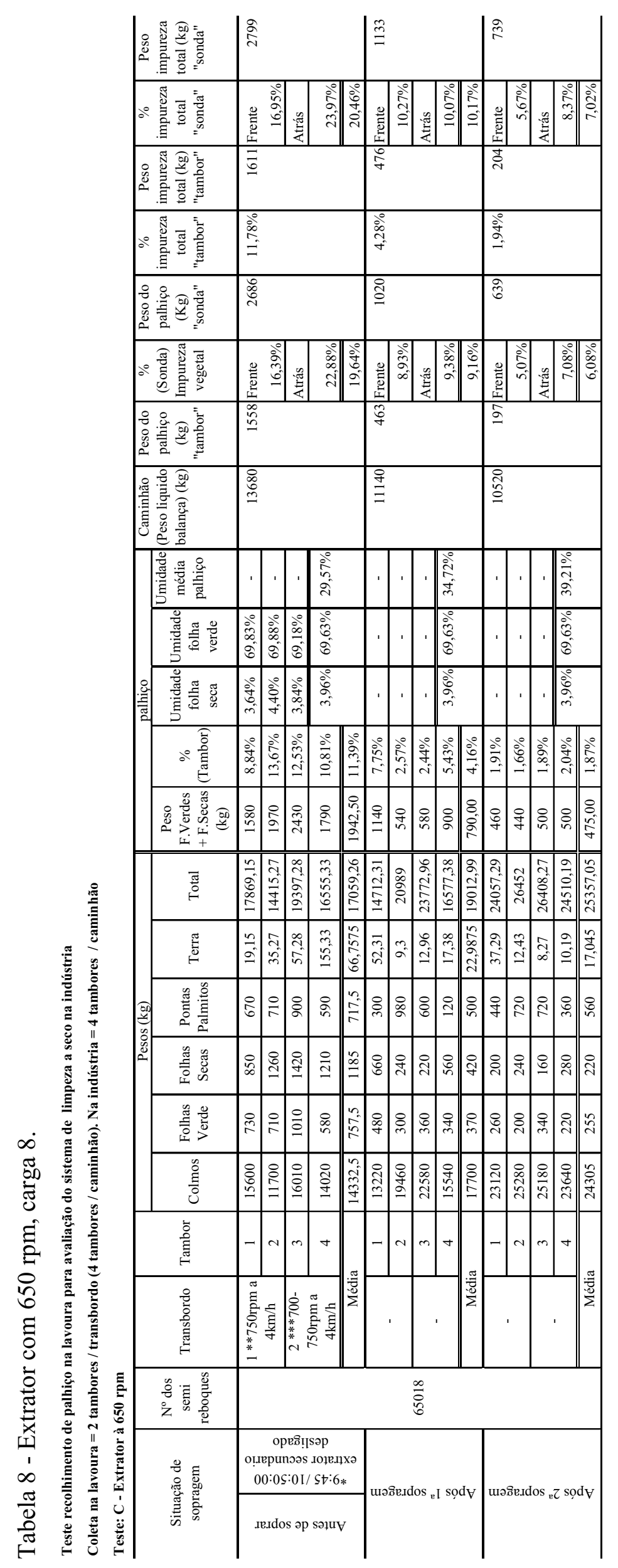




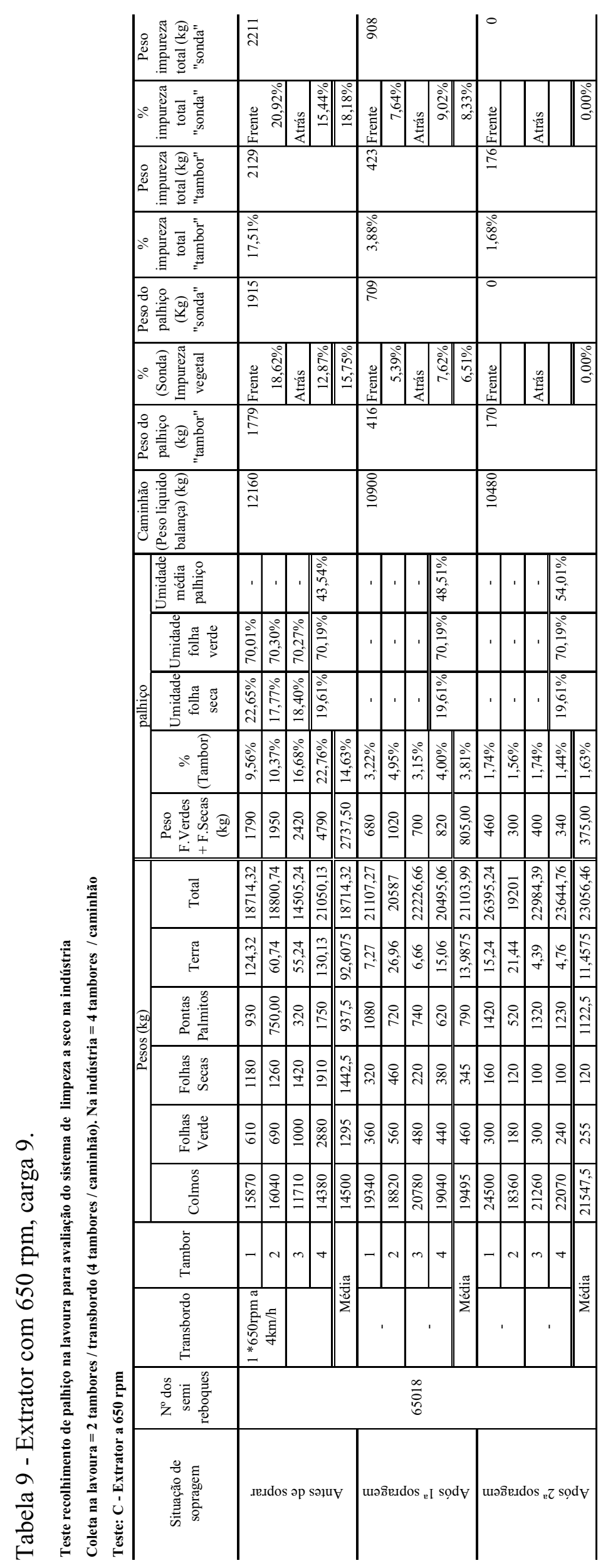




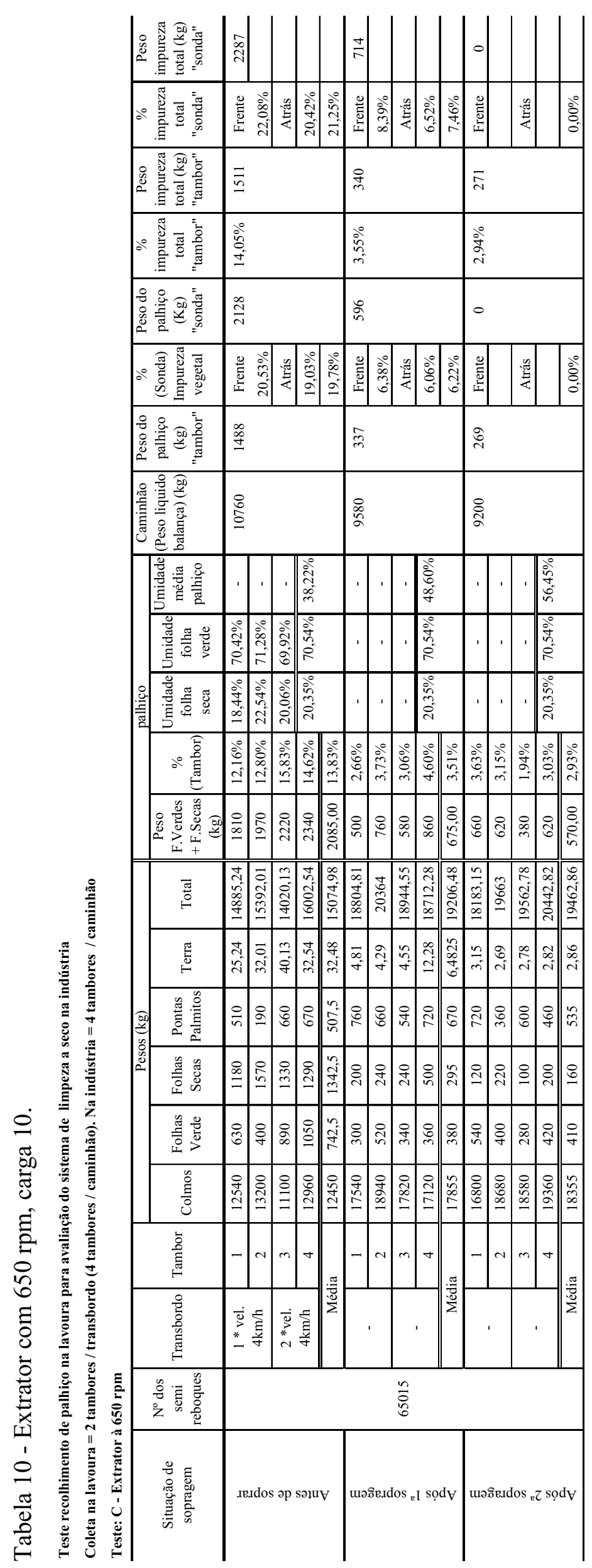




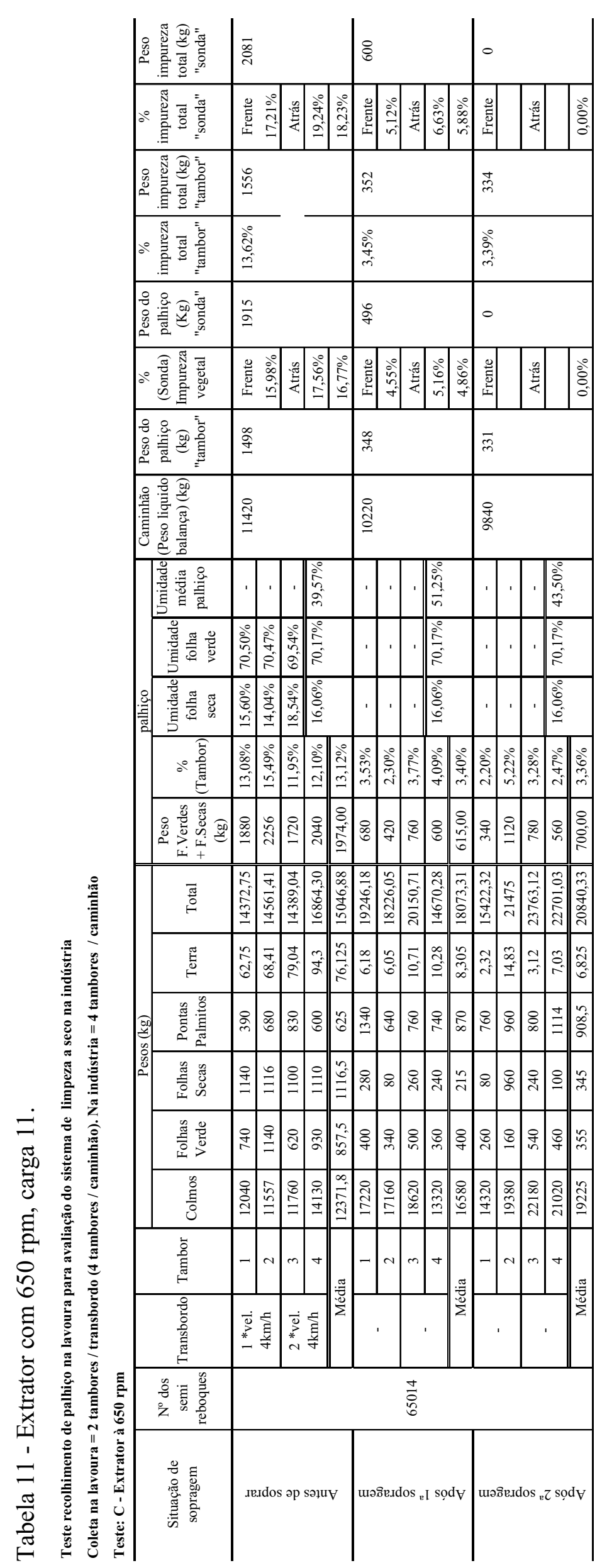




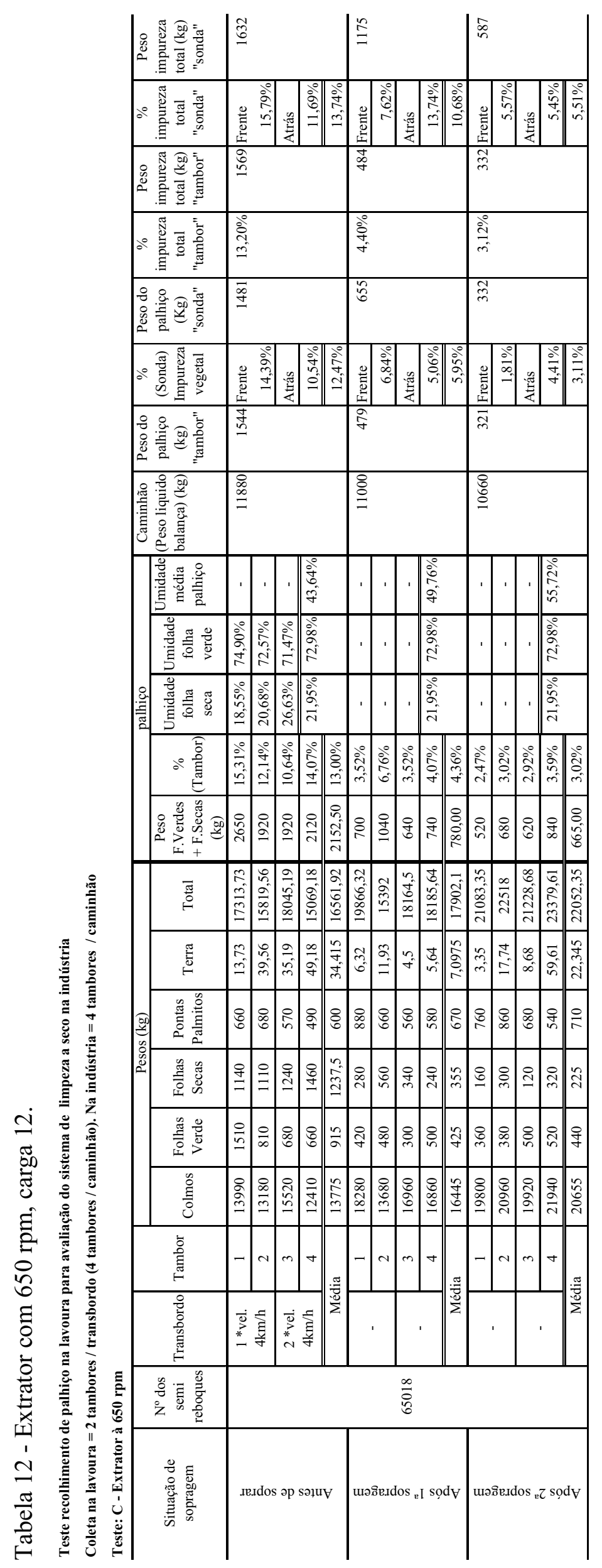




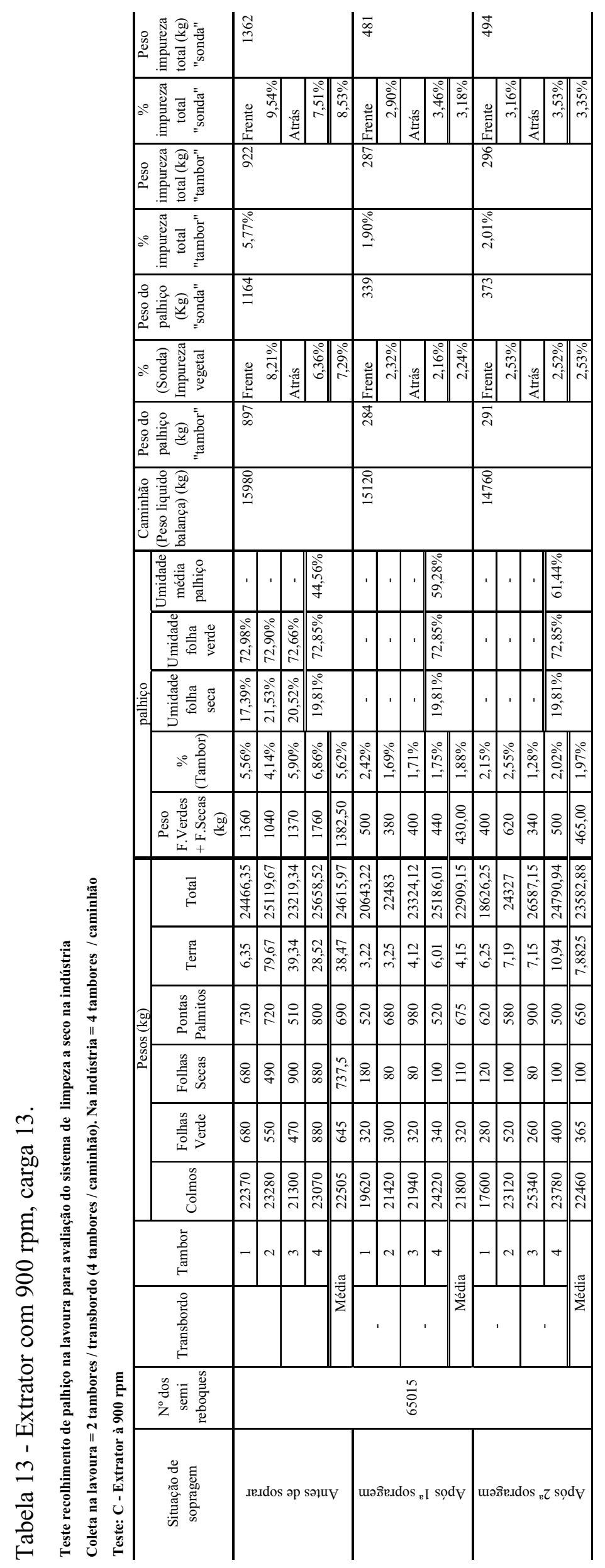




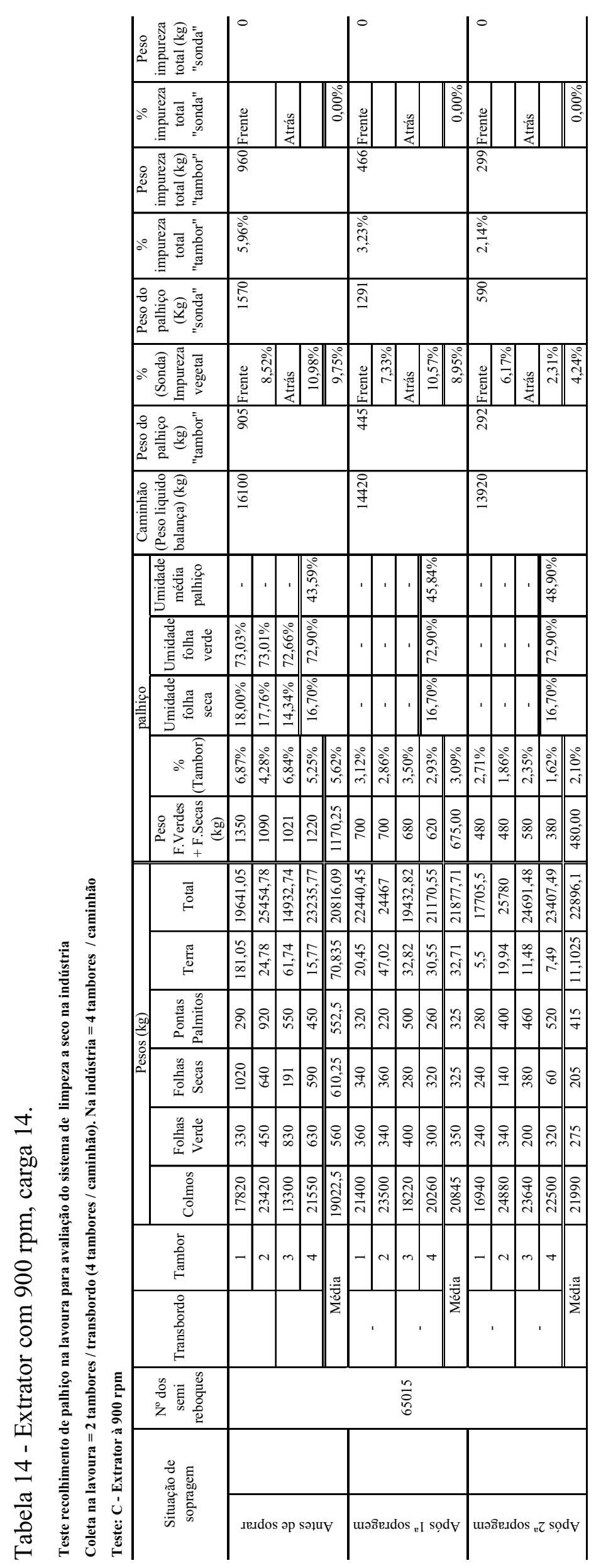




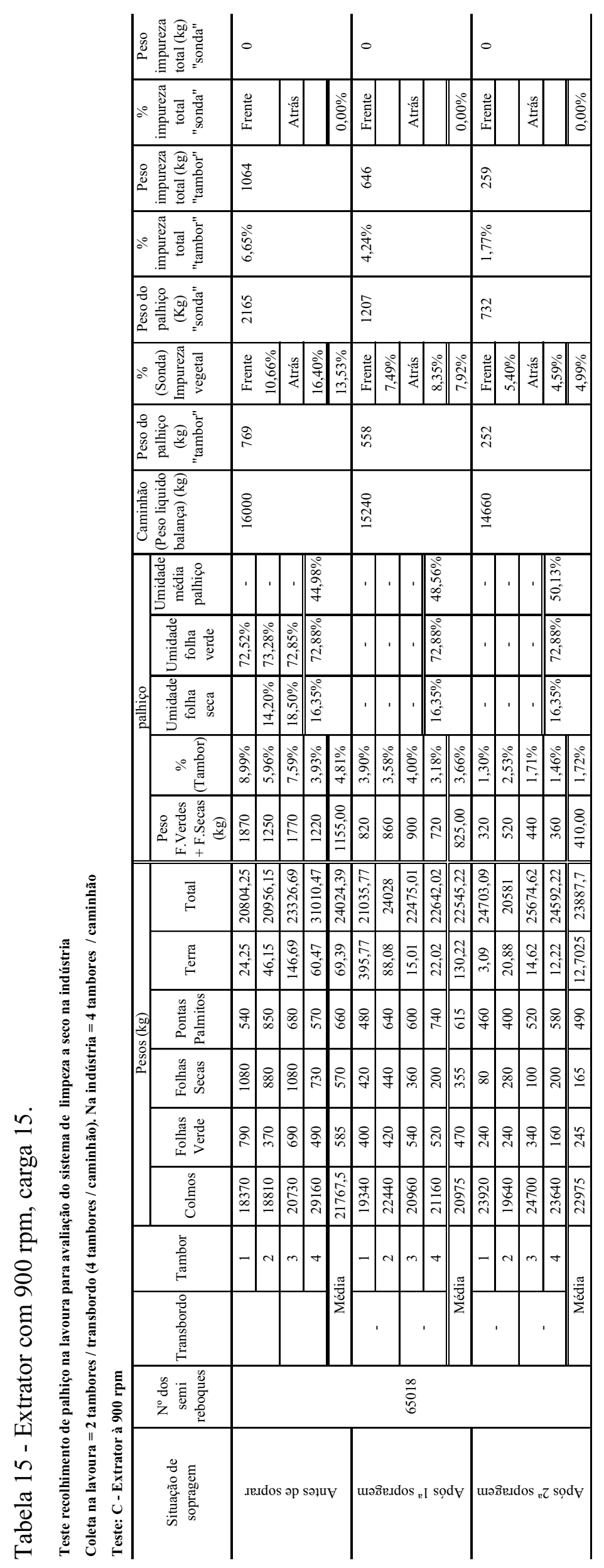




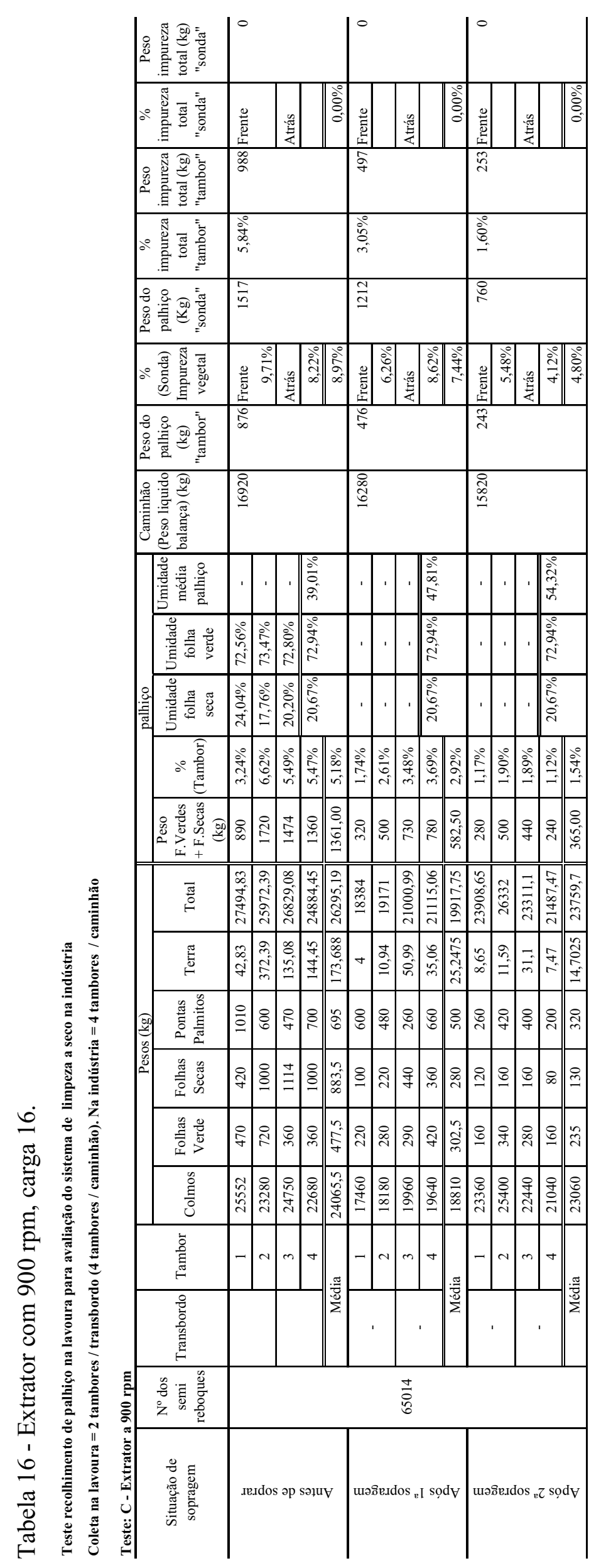

